\title{
فاعلية برنامج قائم على إدارة الذات في تصسين السلوك الصحي لدى المراهقين هرضى السكر
}

د.هيام صابر صادق شاهين(")

\section{مستخلص البحث}

أهداف الاراسة: اختبار فاعلية برنامج قائم على تتمية إدارة الذات في تحسين

السلوك الصحي لدى المر اهقين مرضى السكر . لهاب.

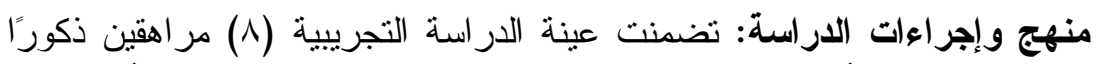

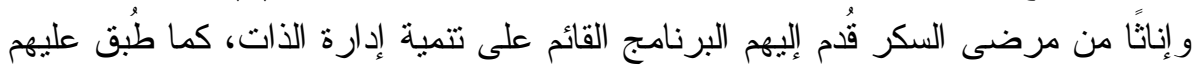

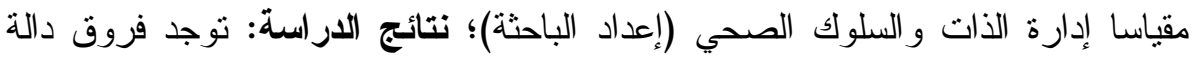
إحصائيًا بين القياسين القبلي و البعدي للمجموعة التجريبية على مقياس (السلوك الصحي)

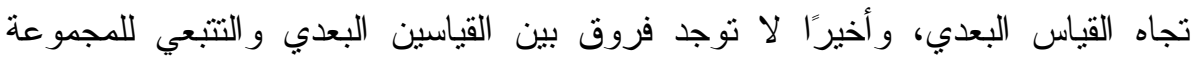

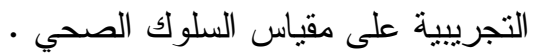
الكلمات المفتاحية: إدارة الذات - السلوك الصحي - المر اهقين مرضى السكر . 
فاعلية برنامج قائم على إدارة الذات في تحسين السلوك الصحي لاى المراهقين مرضى السكر

The effectiveness of a program based on self- management in improving the health behavior among adolescents with diabetes

\section{Dr. Hayam Saber Sadek Shaheen \\ Assistant Prof. of Psychology - Women's Faculty- Ain \\ Shams University}

The Study aims: To test the effectiveness of a program based on self- management in improving the health behavior among adolescents with diabetes. Procedure \& Method: the experimental sample Included (8) of Males \& females diabetic adolescents, who have the program which based on the development of selfmanagement and they have completed: self- management \& health behavior scales (designed by the researcher). The results: There were statistical differences between the pre \& posttest of the experimental group on scale of (health behavior) toward posttest, finally there were no statistical differences between the post \& post- posttest of the experimental sample on study scales.

Key Words: Self- Management - Health Behavior -Diabetic Adolescents.

مقدمة:

شهدت المائة سنة الماضية تغير ات جذرية فيما يتعلق بالأسباب الرئيسة

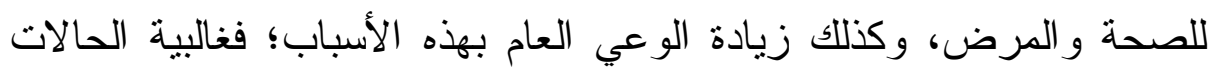

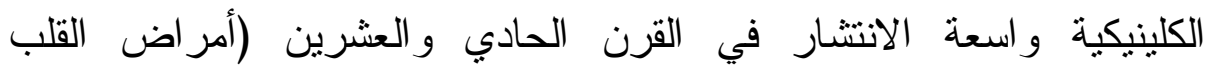
و الأوعية الاموية و السكر و السرطان) تتحدد بواسطة عو امل فسيولوجية ونفسية في آن و احد؛ ولذلك لم تعد الصحة نقطة ارتكاز اختصاصي الطب ونب الحيوي فقط، لكنها تجمع بين رؤى معقدة اجتماعية ونفسية و اقتصادية وطبية؛

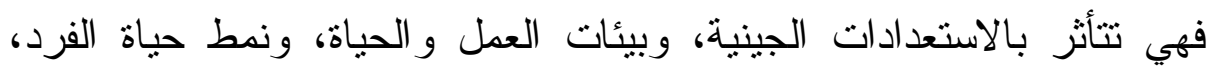

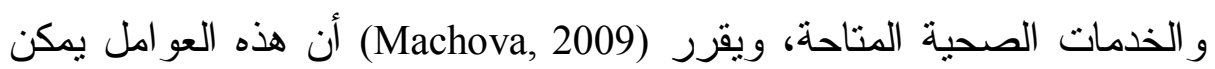


ترنيبها حسب الأهمية على النحو التالي: نمط الحياة بنسبة (.0\%)، و البيئة

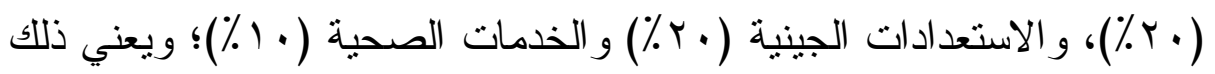

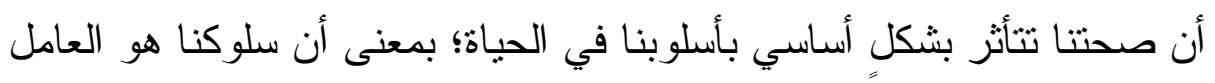

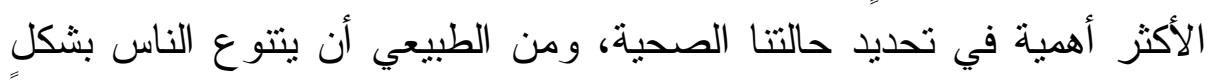

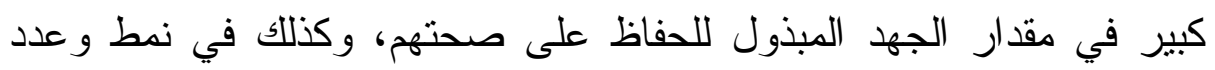
السلوك الصحي الذي يقومون به؛ فالسلوك الصحي يتأثر بقوة بنمط الثخصية، و العديد من العو امل المعرفية والانفعالية (مثل المخاطر و التهديدات المُدركة -

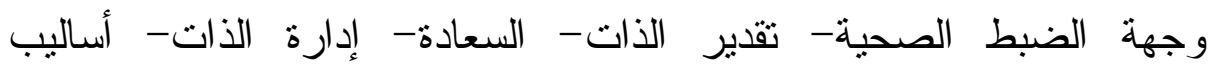

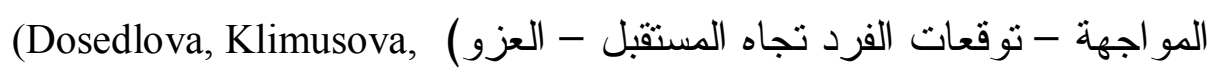
- Buresova, Jelinek, Slevachova \& Vasina, 2015) يعتمد السلوك المعزز للصحة في مرحلة الرشد على عادات المعيثة

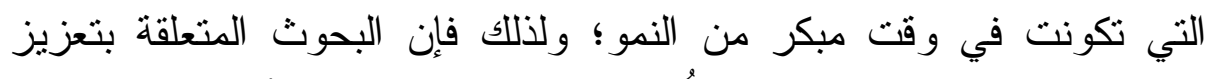

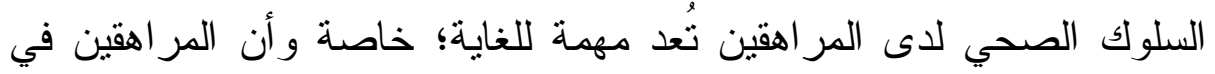
فترة انتقالية ديناميكية تعبر بالفرد من الطفولة إلى الرشد، ويتميز هذا الاتنقال بالتغيرات السريعة و المترابطة في الجسم و والعقل و العلاقات الاجتماعية .(Chen, Lai, Chen \& Gaete, 2014) يُعد مرض السكر من أكثر الأمراض المزمنة المنتشرة بين الأطفال

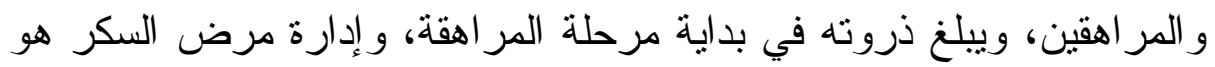

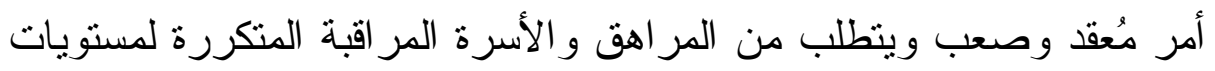

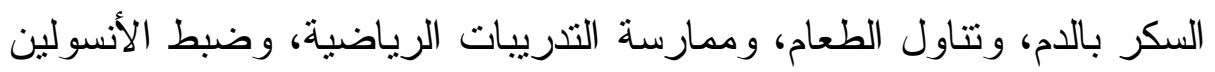

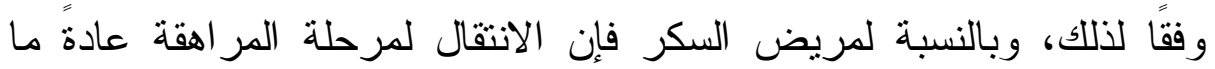
يرتبط بإدارة الذات الضعيفة وتدهور السيطرة على عملية التمثيل الغذائي

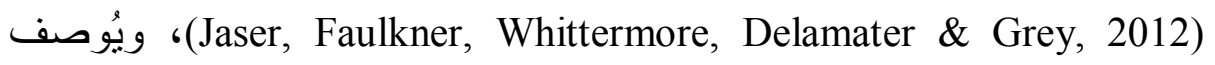
مرض السكر بأنه من أكثر الأمراض المزمنة ذات المنطلبات النفسية

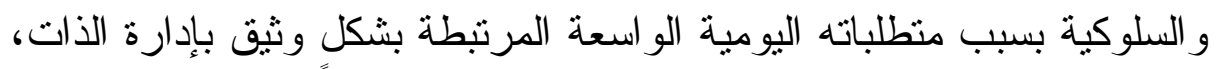


ولكون المراهقة فترة نمو فإن ذللك يُضيف تحديًا خاصًا للمر اهقين مرضى إنى

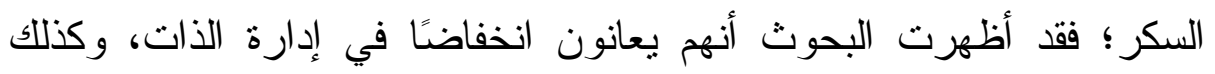

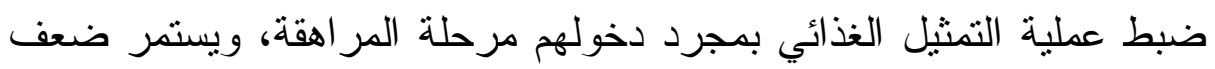
ضبط عملية التمثيل الغذائي خلال فترة المر اهقة (Verchota, 2014) . وفي ضوء ما تقدم فإن البحوث المتعلقة بالسلوك الصحي لابد وأن تهنم بيحث المتغير ات الثخصية منل إدارة الذات؛ حيث يفترض (Jessor, 1984) أن دراسة السلوك الصحي للمر اهقين لابد وأن تركز على العو امل العديدة

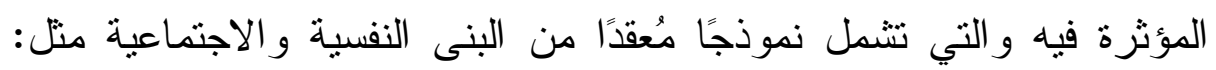

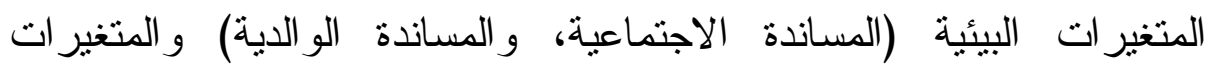

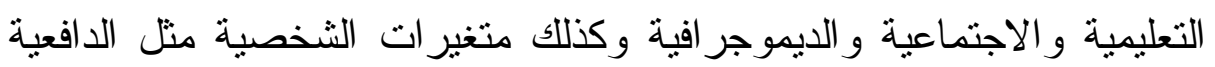
و إدارة الذات (Rorres, 1995).

وتمثل إدارة الذات محورًا مهمًا في إدارة مرض السكر ؛ حيث أثنارت نتائج البحوث إلى أنها تحسن نوعية حياة المريض؛ فهي تقلل من شدة

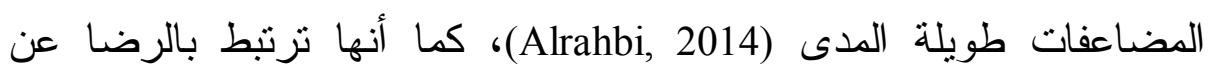
نوعية الحياة، وكذلك بالتحكم في عملية التمثيل الغذائي، ومستوى السكر بالدم؛ وخاصةً لدى المر اهقين، وهكذا فإن إدارة الذات هي أمر بالغ الأهمية لتحسين

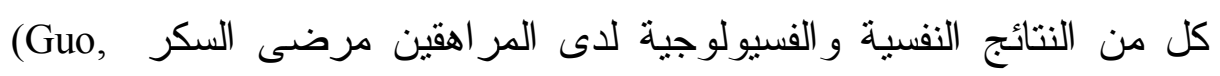
.Dixon, Whittemore \& He, 2012) ويفترض الباحثون أنه بتعزيز إدارة الذات فإن كل مريض سوف نتمو

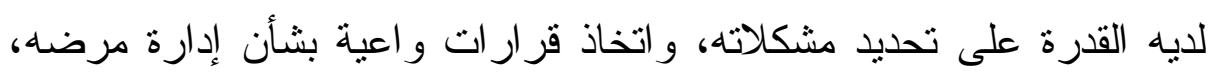
ويضع أهدافًا و استر اتيجيات و اقعية لتحقيق هذه الأهداف مع اعتقاده في قدرته على إنجاز هذه المهام (Thompson, 2010). بناءً على ما سبق تمنل إدارة الذات مُتطلب أساسي وضروري لر لرعاية

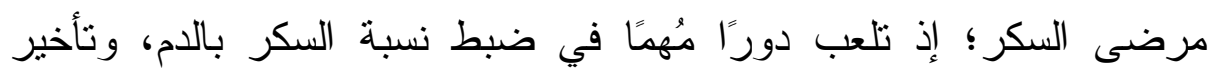
ظهور مضاعفات المرض، كما أن انخفاضها من الممكن أن يؤدي مضاعفات 
تتطلب دخول المستشفى، واستخدام الخدمة الطبية وزيادة الأعباء على نظام

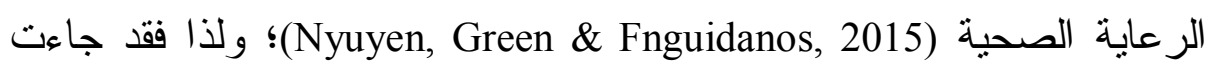
هذه الدراسة بهدف اختبار فاعلية برنامج قائم على نتمية إدارة الذات في

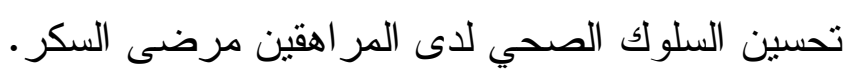

\section{مشكلة الدر اسة:}

تشير الإحصاءات إلى وجود ما يقرُب من r. أليار مر اهق؛ بنسبة ا:

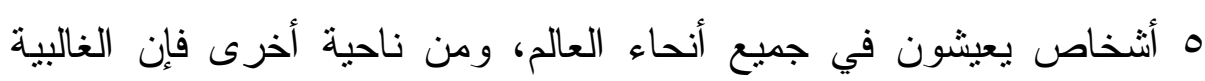

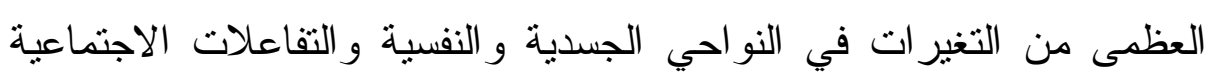

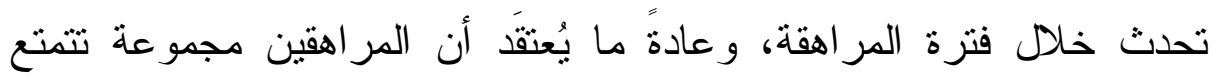

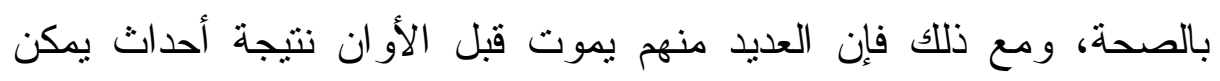

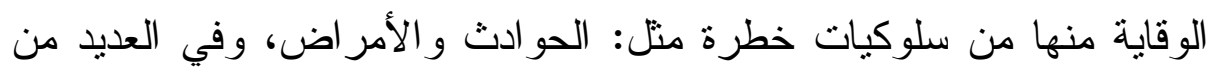

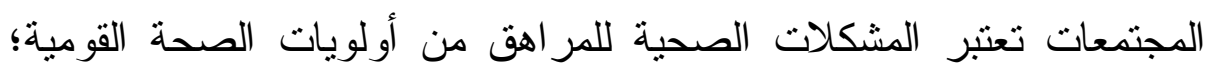

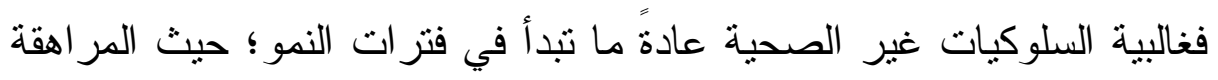

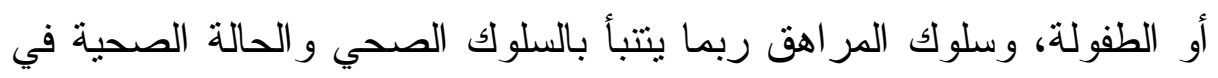
مرحلة الرشد المبكر؛ ولذلك فإن بحث الحاجات الصحية للمر اهق، وتعزيز

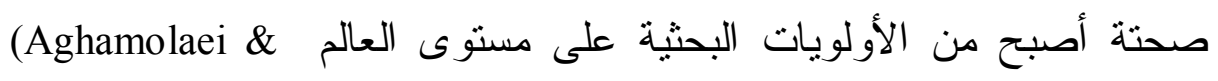

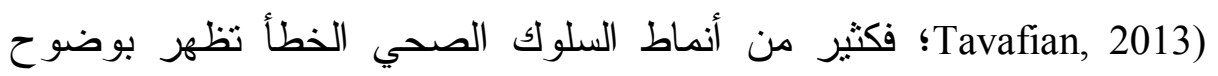
خلال فترة المر اهقة بما يعمل على خلق قاعدة على الددى الطويل من العادات

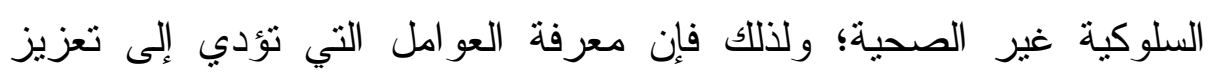

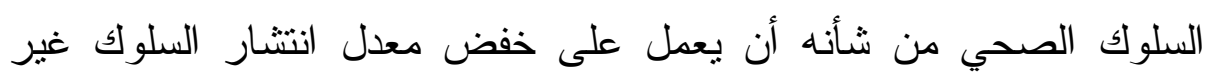
الصحي لدى المر اهقين (Huntsinger \& Luecken, 2004). وتثير التقارير إلى تضاعف معدل الحالات المرضية المزمنة بين

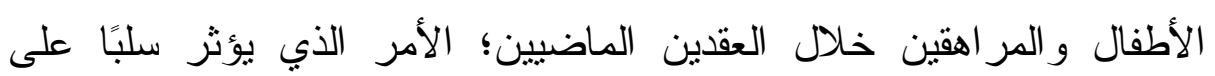

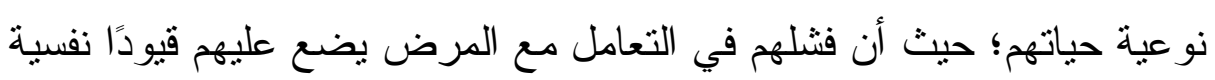

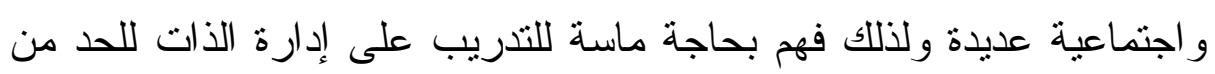


مخاطر المضاعفات الثانوية للمرض المزمن ونسبتة، وزيادة فاعليتهم الذاتية التي من شأنها أن تزيد من احتمالية أن يعيش المر اهق بشكلٍ مستقل طو ال

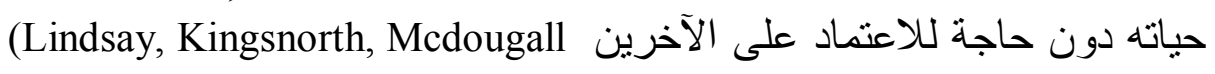
. \& Keating, 2014) ويُعد مرض السكر من أهم و أخطر المشكلات الطبية التي تنتشر بين

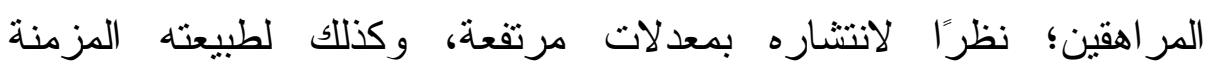

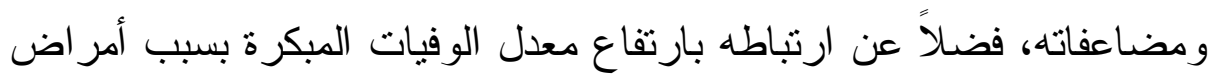

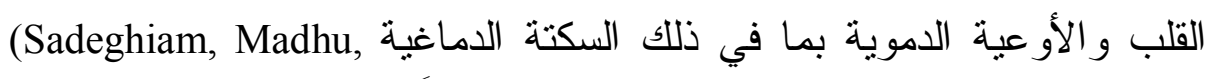
Agrewal, Kannan \& Agrawal, 2016)

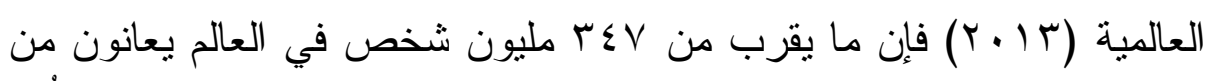

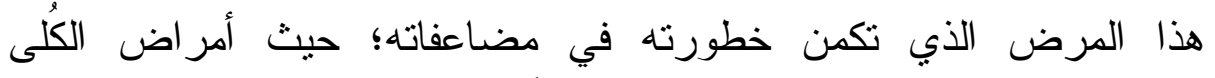

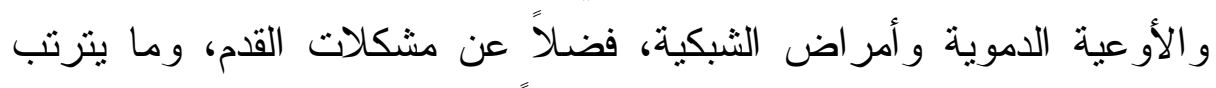

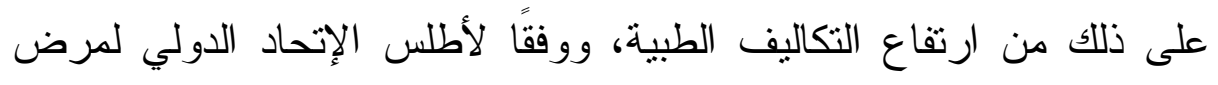

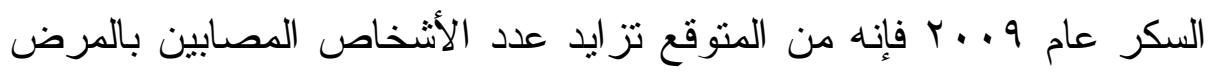

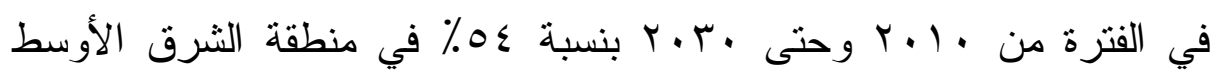

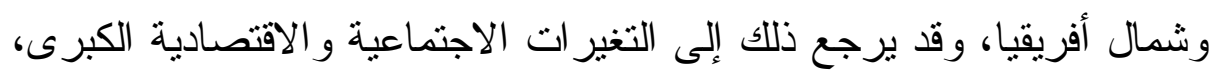
و انخفاض معدل وفيات الأطفال، وارتفاع متوسط العمر، و التي حدثت على ولى ولى ولى مدى العقود الثناثة الماضية في هذه المنطقة، إذ حدث نغير هائل في نمط

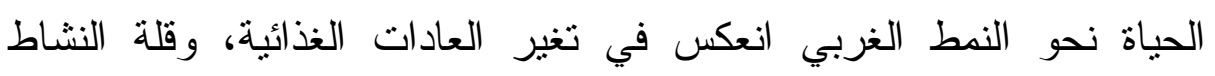

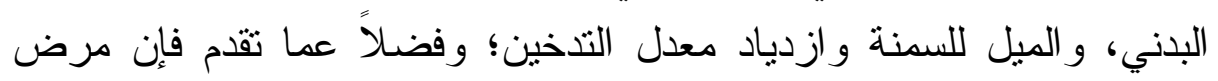
السكر يمنل حالة مستمرة خلال الأربع وعشرين ساعة باليوم، وكل أيام

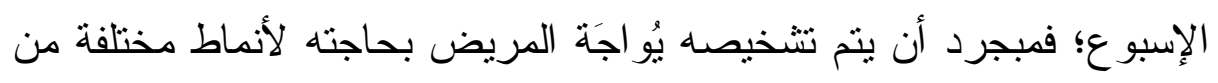

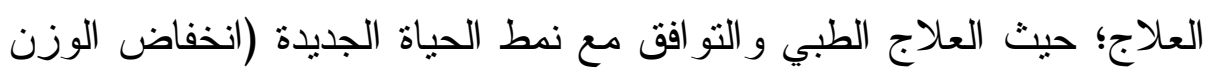
وضبط التغذية و التدريب)، ولذلك فان مريض السكر بحاجة ماسة للتشجيع

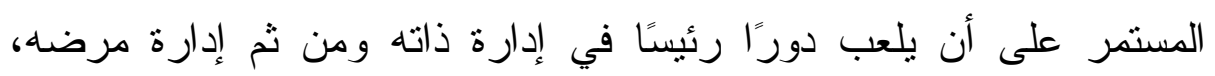


ونتير نتائج العديد من الدراسات في هذا الصدد إلى أن المرضى الذين

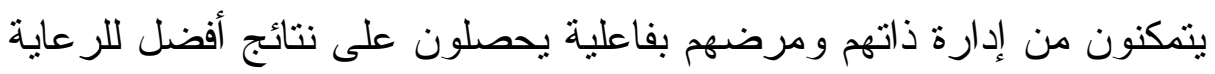
الصحية (Shakibazadeh, Rashidian, Larijani \& Shojaeezadeh, 2012) ولما كان مرض السكر هو مشكلة طبية عالمية وحرجة، ويمنل حالة

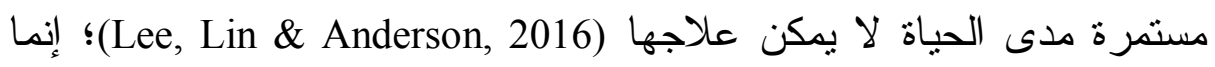
يمكن السيطرة على مستوياته بالدم فربما يكون العامل الأكثر أهمية هو إدارة لادها

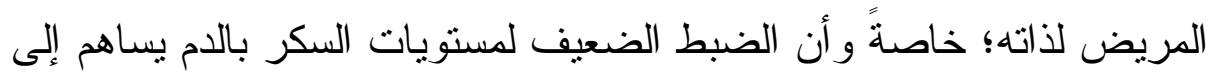

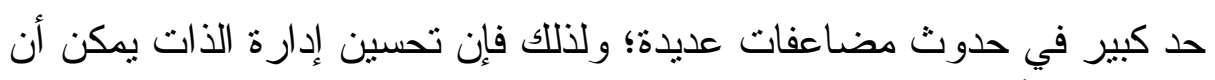
يكون مدخلاً مهمًا لتحسين مآل السكر وتقليل مخاطر مضاعفاته على المدى ولى لئل

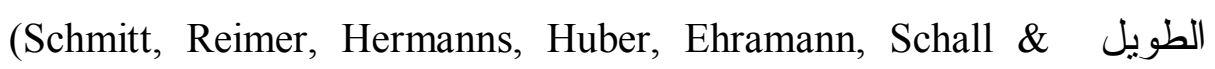

.Kulzer, 2016)

أثنارت بعض الدراسات أن برامج التثقيف الصحي لها معدلات نجاح

تُقدر فقط بـــ ـ ـ ولذلك فإن التخخلات الحديثة الفعالة لمساعدة هؤلاء

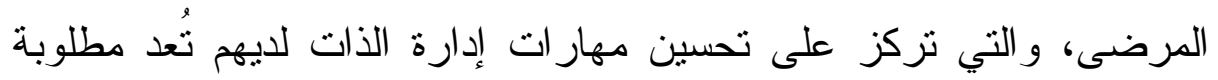
بشكلٍ جاد (Song, Xu \& Sun, 2014)؛ ولذلك توصي الجمعية الأمريكية ADA

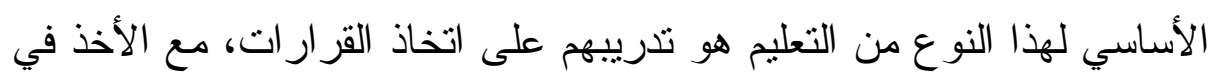
الاعتبار طبيعة مرضهم، ومثل هذه التذخل من شأنه أن يحسن النتائج الطبية

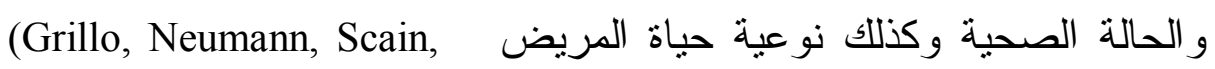
Rozeni, Gross \& Leitao, 2013)

وتركز معظم التدخلات القائمة على تتمية إدارة الذات على تعليم الناس كيف يتعاملون بفاعلية مع أمر اضهم المزمنة؛ فهم يحتاجون إلى إدارة مرضهم

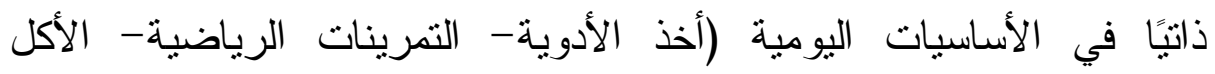
الصحي- الإقلاع عن التذخين)، ولذلك فإنهم ربما يستقيدون بشكلٍ كبير من الإنهائه التدخل القائم على تتمية إدارة الذات الذي يزودهم باستر ولتيجيات سلوكية 
و معرفية للتعامل مع الأنماط المختلفة من المشكلات اليومية، وليس التدخلات

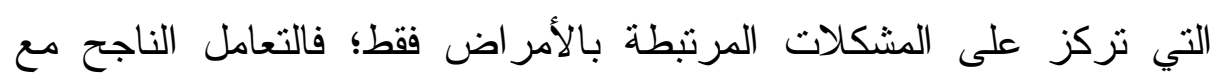
الحالات المزمنة هو عملية طويلة المدى لتحقيق والحفاظ على الصحة و الرفاهة بشكل عام، وتوجد معلومات قليلة عن العلاقة بين إدارة الذات

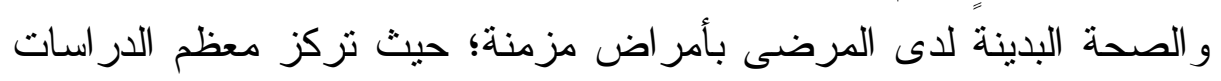
على إدارة الذات المرتبطة بالمرض فقط، في حين يوجد نقص في الدراسات التراته التي تبحث مهار ات إدارة الذات ودورها في الحفاظ على الصحة فئرة عمومًا (Gramm \& Neiboer, 2012)، كما أن غالبية البحوث المعنية ببحث إدارة الذات لدى المرضى بأمر اض مزمنة قد ركزت على عينات كبار السن؛ حيث

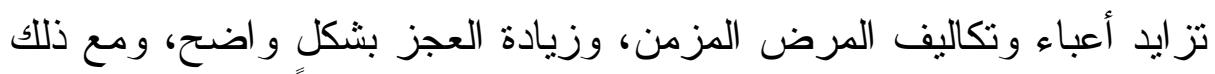

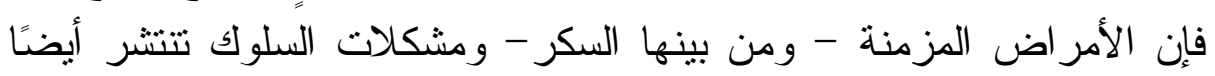
بشكلٍ واضتح في مرحلة المراهقة؛ وتؤثر في المر اهقين بطرق عديدة؛ فبالإضافة لمتطلبات النظام العلاجي المعقد نجد أنه قد يؤثر في معدل نمو

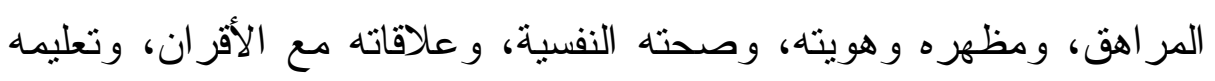
و عمله فيما بعد، كما أنه يؤثز بشكلٍ عميق على وفئه كفاءة الأسرة وفاعليتها،

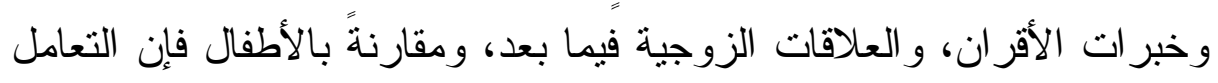

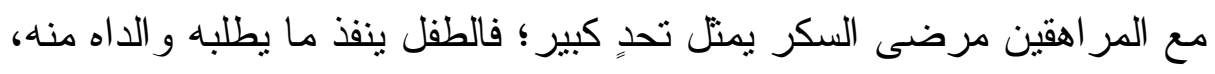
أما المر اهق فلن ينفذ بتلقائية ما يُطلب منه فبمجرد أن ينضج لهن لابد وأن يتعلم

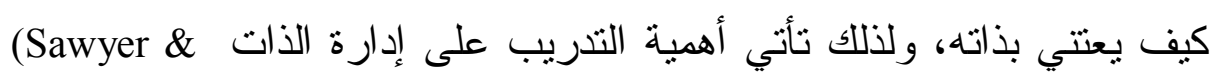
.Aroni, 2005)

يتضح مما تقدم أنه مع انتشار الأمراض المزمنة في المراهقة، مناف و انخفاض معدل الوفيات فإن هنالك حاجة ملحة ومتز ايدة لتعليمهم كيفية الإدارة

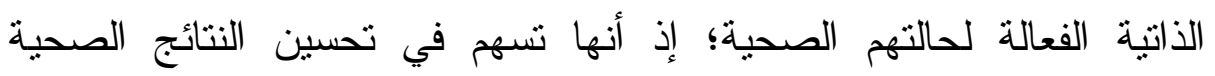
ونوعية الحياة، وتقلل من معدلات المرض و الزيار ات الطبية الطارئة وتكاليف

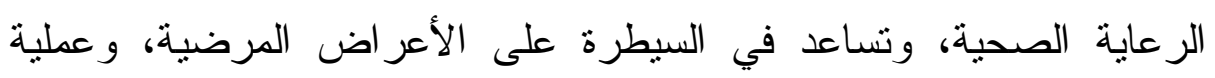


العلاج و الآثار النفسية و الجسدية للمرض، وهي ضرورية جدًا لتحقيق تأثير

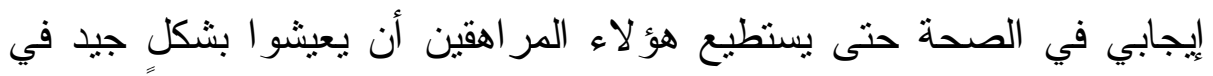
مرحلة البلوغ (Lindsay et al., 2014).

استتادًا لما تقدم تمت مر اجعة الدراسات المعنية بهذه المتغيرات، دهات وتبين عدم وجود دراسات عربية - في حدود اطلاع الباحثة- اهتمت ببحث هُه إدارة الذات و علاقتها بالسلوك الصحي لدى المر اهقين مرضى السكر، وكذللك عدم وجود در اسات اهتمت بتتمية إدارة الذات لديهم، كما تبين وجود ارتباط موجب بين إدارة الذات و السلوك الصحي لدى المر اهقين مرضى السكر؛ (Thompson, 2010; Al- Khawaldah; Al Hassan \& Froelicher, 2012) وكذلك بين إدارة الذات ومؤشر ات تحسن الصحة البدنية، وضبط نسبة السكر (Gramm \& Nieboer, 2012; Gua, Whittermore, Jeon Grey \& بالدم Zhou, 2015)

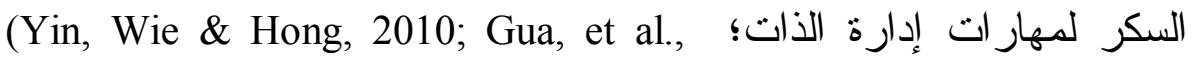
(2015، وأهمية هذه المهارات لارنباطها بارتفاع معدلات كل من الرفاهة

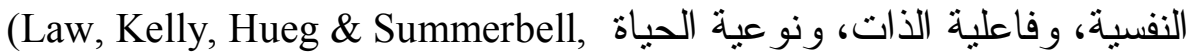
2002; Sarkar, Fisher \& Schillinger, 2006; Jaser, et al., 2012) عما تقدم أسفرت هذه الدراسات عن أهمية تتمية إدارة الذات لدى المر اهقين مرضى السكر؛ لما لها من دور في تدعيم استقلاليتهم و اعتمادهم على إنى (Opipari- Arrigan, Kichler \& أنفسهم، وتحسين النتائج الصحية Fredericks, 2005; Mulvancy, Rothman, Wallston, Lybarger \& ؛ Dietrich, 2010; Bulaclac, 2011) (Musekamp Bengel; Schuler \& Faller, 2015; الإرشادية في تتميتها لديهر (Mc Gowan, 2015) وبناءً على ما سبق يمكن تحديد مشكلة الدراسة في السؤ الين التاليين:

ا. هل يتحسن أداء المجموعة التجريبية من المر اهقين مرضى السكر على مقياس السلوك الصحي في القياس البعدي للبرنامج الإنمائي ؟ 
r. . هل يختلف أداء المجموعة التجريبية من المر اهقين مرضى السكر على مقياس السلوك الصحي باختلاف القياسين البعدي والتتبعي (بعد شهر من انتهاء البرنامج) للبرنامج الإنمائي ؟ أهداف الدر اسةة:

تهدف هذه الدر اسة إلى اختبار فاعلية برنامج قائم على تتمية إدارة الذات في تحسين السلوك الصحي لدى المر اهقين مرضى السكر . أهمية الدراسة: الهية

\section{تستمد هذه الدر اسة أهميتها من الاعتبار ات التالية؛}

ا. جذب الاهتمام لفئة المر اهقين من مرضى السكر في محاولةٍ لمساعدتهم على حل مشكلاتهم و الارتقاء بصحتهم النفسية و البدنية.

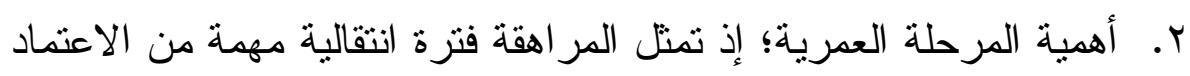

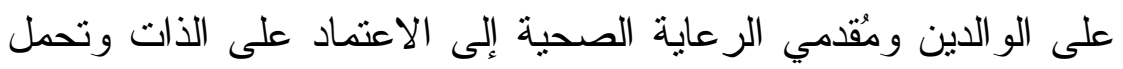
المسئولية الثخصية في الرعاية الصحية، ومتابعة البرنامج العلاجي؛ الأمر الذي يعزز أهمية التخخل في هذه الفترة لاعم وتتمية القوى

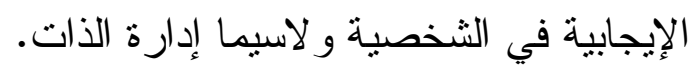
r. نُدرة الدراسات العربية -في حدود اطلاع الباحثة- التي اهتمت بتتمية إدارة الذات لدى المر اهقين مرضى السكر لمساعدتهم على التحكم في مرضهح و التعايش معه. ء. أهمية متغيري إدارة الذات و السلوك الصحي؛ إذ تمثل إدارة الذات الخط الدفاعي الأول للمر اهق مريض السكر الذي يُمكنه من التعايش الصحي إنهي

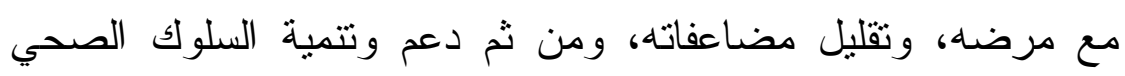
لايه، والذي يمنل غاية مهمة لكلٍ من المرضى و الأصحاء على حد سو اء. ه. الأهمية السيكوميترية؛ حيث إعداد مقياسين لتقدير إدارة الذات و السلوك 
الصحي لاى المر اهقين مرضى السكر؛ الأمر الذي قد يسهم في إثز اء المكتبة العربية بمقاييس جديدة .

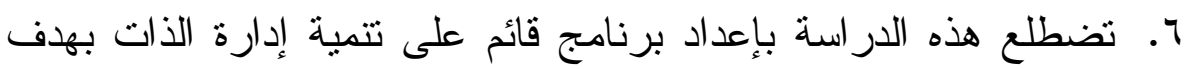
تحسين السلوك الصحي، وهذا البرنامج -في حال ثبوت فاعليته- يمكن استخدامه وتطبيقه على قطاعات أكبر من المر اهقين مرضى السكر؛ الأمر الذي قد يسهم في مساعدتهم و الارتقاء بصحتهم النفسية و البدنية. V. الأهمية التطبيقية؛ يمكن أن تساعد نتائج هذه الدراسة الإختصاصيبين النفسيين و اختصاصي الصحة العاملين مع المر اهقين مرضى السكر في الهيه تصميم البر امج الإرشادية التي تهدف دعم الجوانب الإيجابية لديهم كمحاولة لتشجيعهم وتدريبهم على ضبط مرضهم و التعامل معه بفاعلية . مُصطلحات الدر اسة:

تضطلع هذه الدر اسة بتتاول المصطلحات التالية؛ ا . . إدارة الأات Self- Management: في ضوء تحليل تعريفات إدارة الذات في قاموس (APA, 2007) ولاى كل من \& Barlow, et al., 2002; Xue \&) Sun, 2012; Mezo \& Short, 2012; Lee, et al., 2016) الأجنبي، و (جابر عبد الحميد جابر، و وعلاء الدين كفافي، 9 ( إ؛ أنور

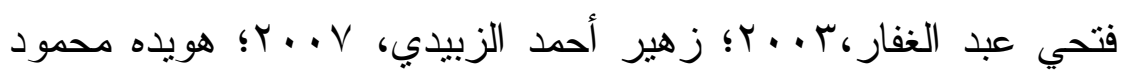

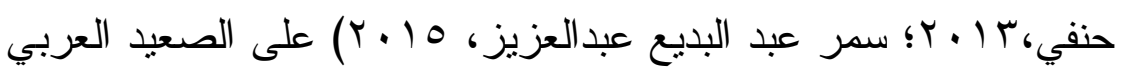
نخلص إلى تعريفها نظريًا بأنها "مجموعة المهار ات و الاستر اتيجيات التي يستخدمها الفرد في المواقف المختلفة بهدف التحكم الذاتي في سلوكه وتوجيهه لتحقيق أهدافه، وتتضمن مهار ات مر اقبة وتوجيه وتقييم

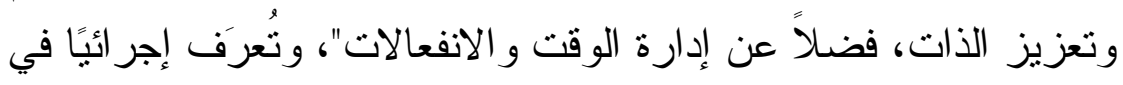

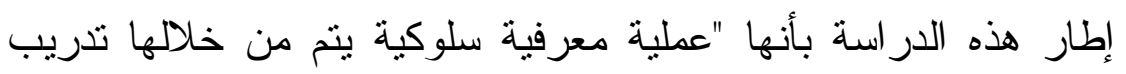

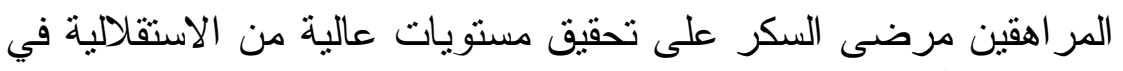

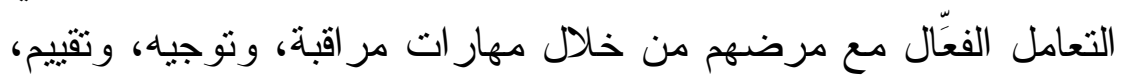


وتعزيز الذات، وذلك كما تعكسه الدرجة التي يحصل عليها المفحوص على المقياس المُعد في هذه الدر اسة" . r. السلوك الصحي Health Behavior: في ضوء تحليل تعريفات كل من (Ferguson \& Danial, 1995; Taylor, 2003)

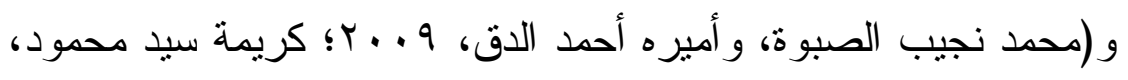

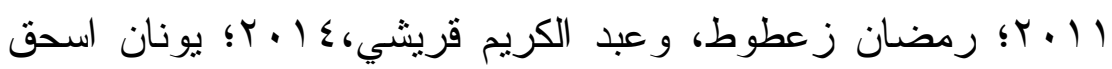

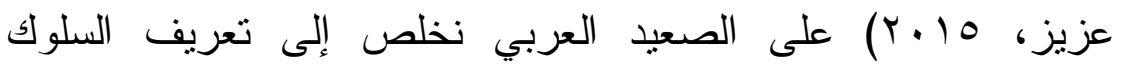
الصحي إجر ائيًا بأنه "أبي نشاط يقوم بـه الفرد بهدف الحفاظ على حالته الصحية، وتعزيزها، ومنع تفاقم مرضها من قبيل ممارسة الأنشطة

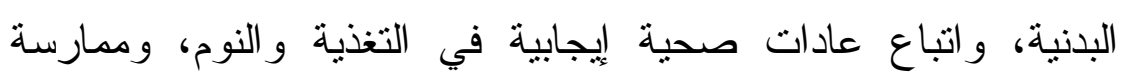

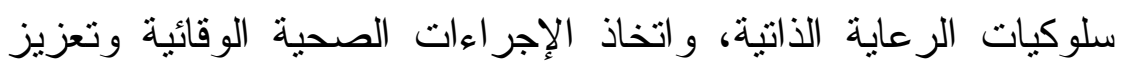

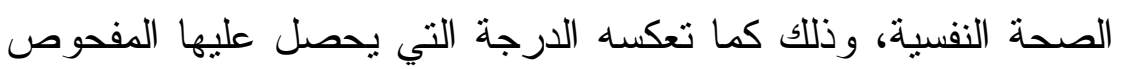

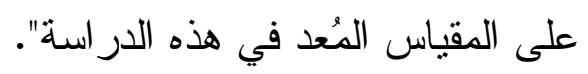
r. مرض السكر Diabetes Mellitus: هو مرض إستقلابي (أيضي) مزمن هده Metabolic Disease نتيجة لنقصٍ نسبي أو كامل في الأنسولين Hyperglycemia

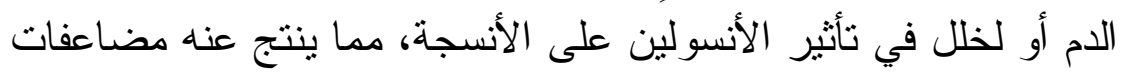

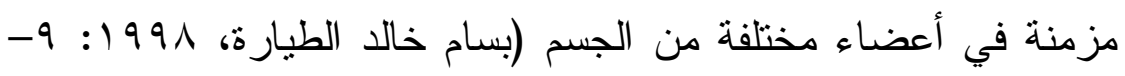

الار اسات السابقة: - ت

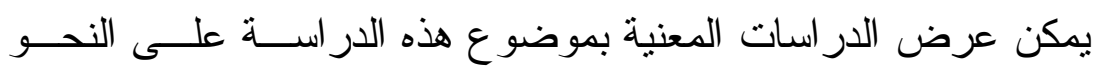
التالي:

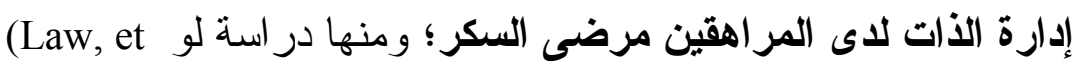
al., 2002)

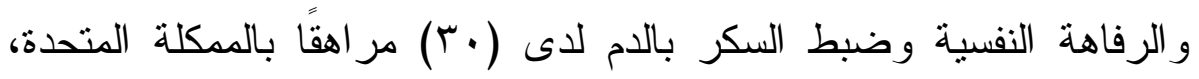


وتوصلت إلى أن المعتقدات حول المرض لا نرتبط بسلوك إدارة الذات، في

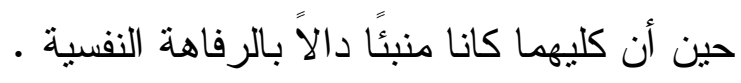
كما بحث ستروش (Storch et al., 2006) العلاقة بين التتمر و إدارة

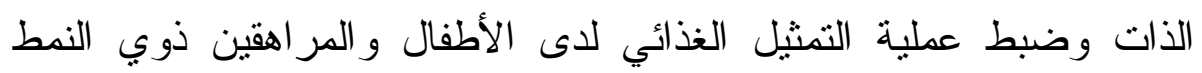

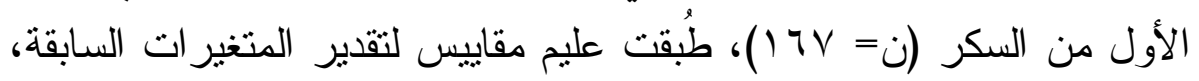

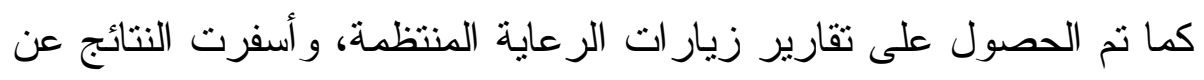

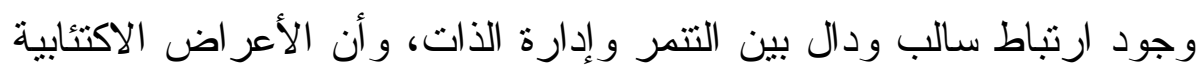
تتوسط هذه العلاقة جزئيًا .

أما دراسة ساركر (Sarkar et al., 2006) فبحث العلاقة بين إدارة

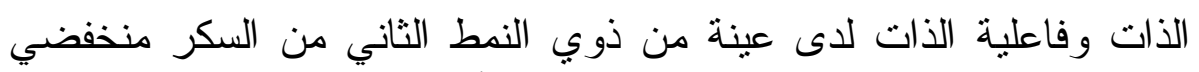

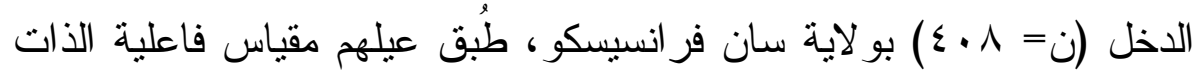

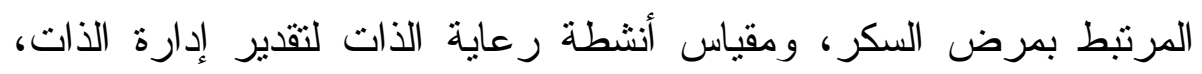

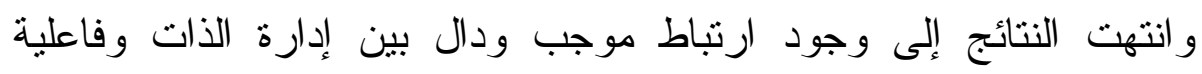
الذات.

كما قام و السون وروثمان وتتثيرنجتون \&allston, Rothman \&

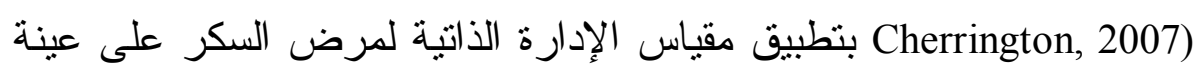

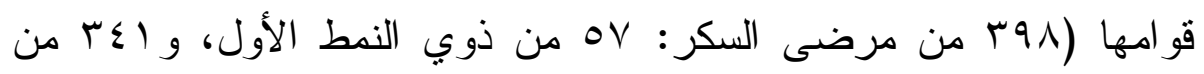

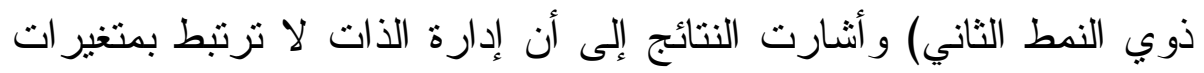

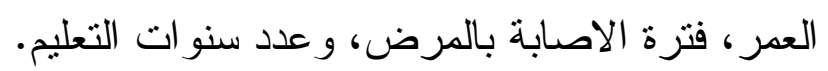

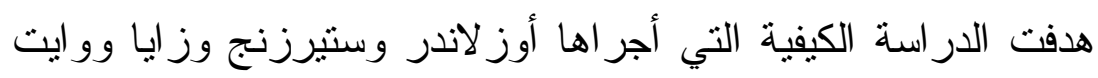
(Auslander, Sterzing, Zayas \& White, 2010)

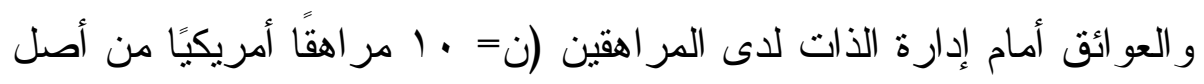

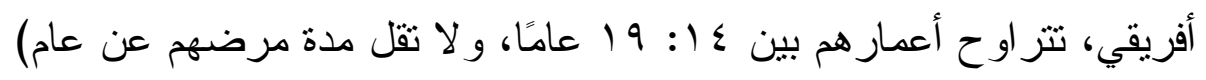

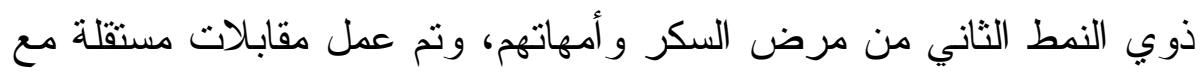

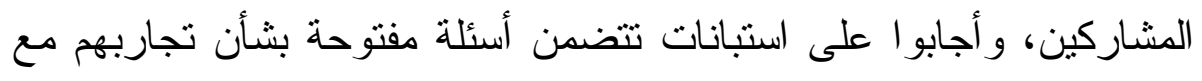


المرض ومصسادر دعم وعو ائق إدارة الذات لديهم، و أثنارت النتائج إلى تماثل

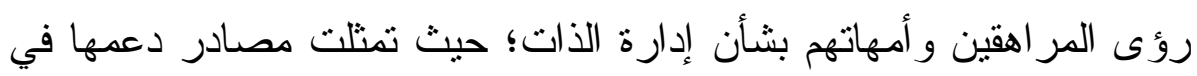

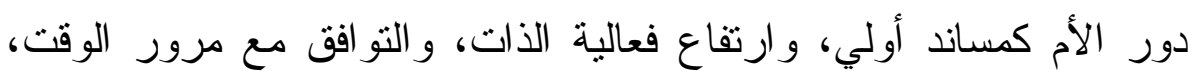

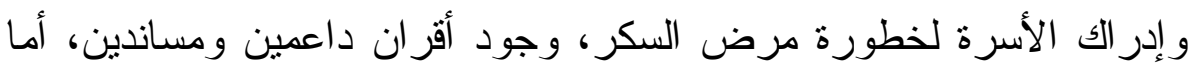

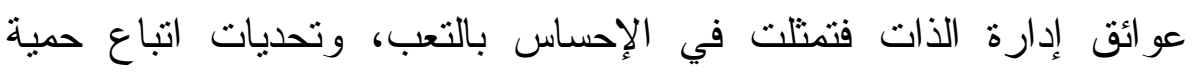
غذائية، والتأثنر السلبي للأقران، و المشكلات التي يتعرض لها المر اهق في بالتي حياته.

ولبحث مستوى إدارة الذات وعلاقته بالمتغير ات الديموجر افية

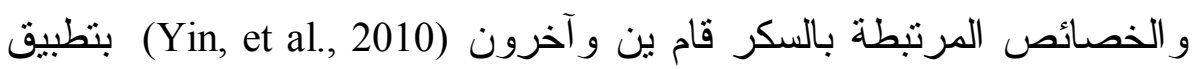
مقياس إدارة الذات و الخصائص المرتبطة بالسكر و واستبانة البيانات

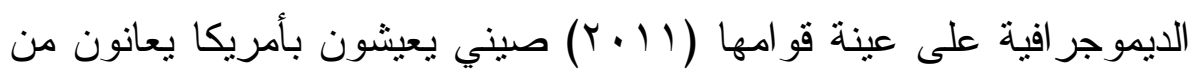

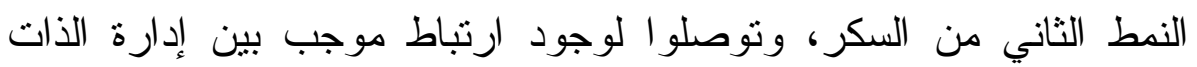
ومستوى التعليم، كما أن ذوي المدة الأطول من المرض، و الذين يستخدمون الأنسولين كعلاج أكثر إدارة للذات من ذوي المدة الأقصر ، ويستخدمون أدوية

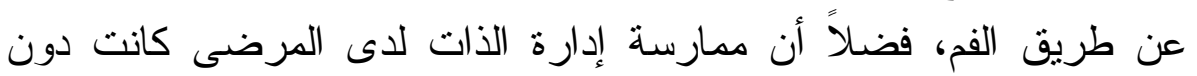
المستوى الأمتل وهو ما يشكل الدافع للقيام بالأبحاث التي تهدف تعزيز الإدارة الذاتية.

وفي سياق متصل سعى هاغي (Hughes, 2011) لبحث الدور الوسيط للمعالجة الإنفعالية (فهر- الاعتر اف- قبول المشاعر) في العلاقة بين التحكم

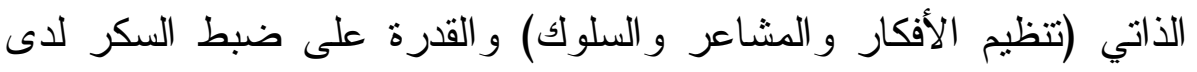

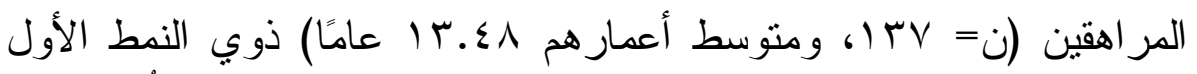

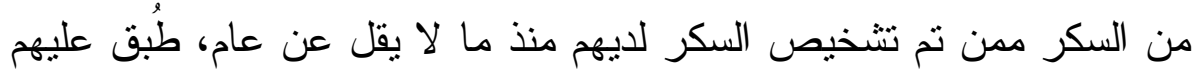
مقاييس: التحكم الذاتي (Finkenayr, et al., 2005) و المعالجة الانفعالية

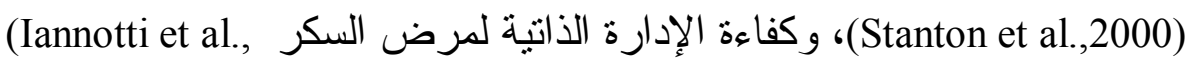
(2006 و أسفرت النتائج عن أن المعالجة الإنفعالية تتوسط بشكلٍ دال العلاقة 
بين التحكم الذاتي وكل من ضبط نسبة السكر بالدم، وعملية التثثيل الغذائي،

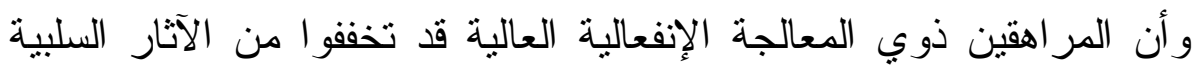

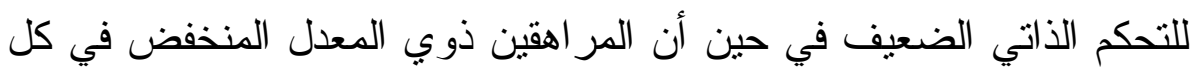

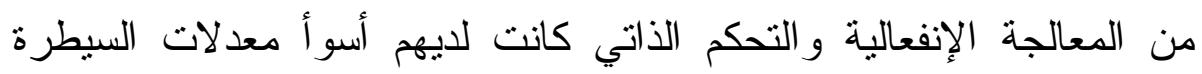
الأيضية . المعال

هدفت دراسة جرمان ونيبور (Gramm \& Nieboer, 2012) بحث قدرة إدارة الذات على التنبؤ بالصحة البدنية و الأعر اض الاكتئئبية لاى عنى عينة

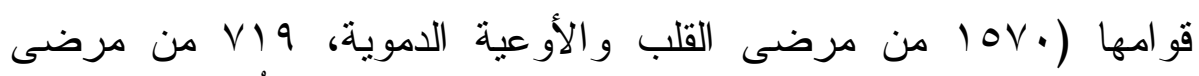

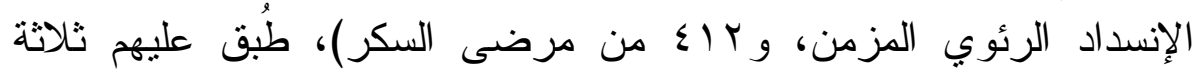

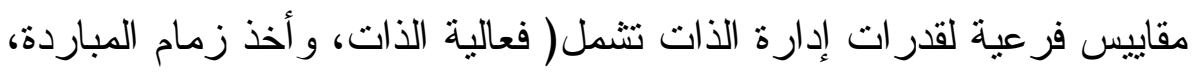

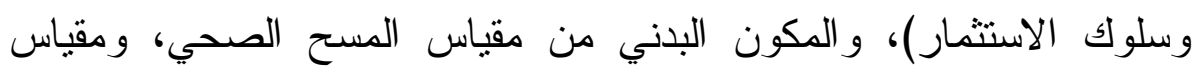

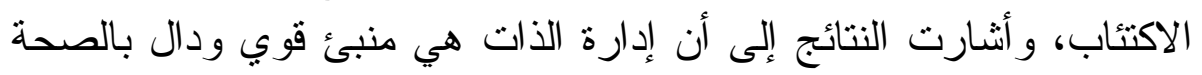

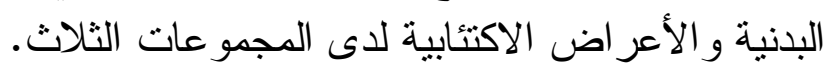

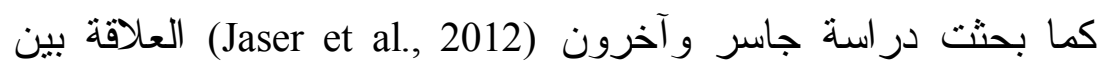

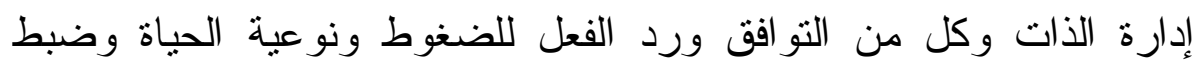

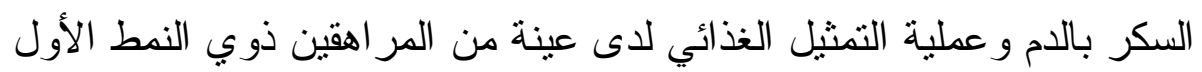

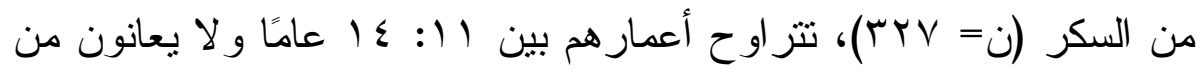

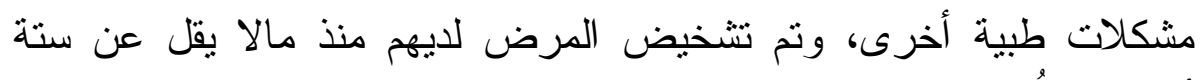

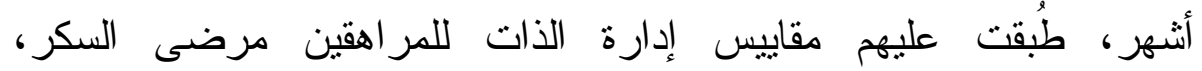

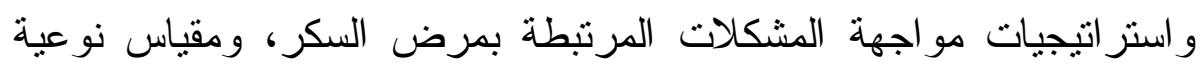

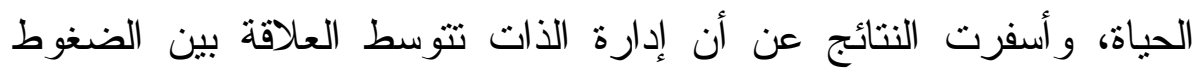
وأساليب مواجهتها من ناحية، ونوعية الحياة وضبط النياة السكر وعملية التنثيل

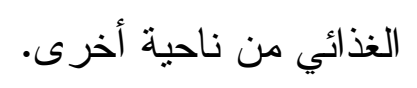

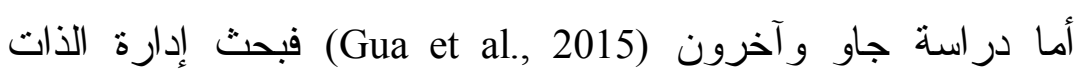

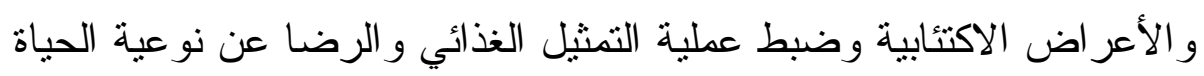

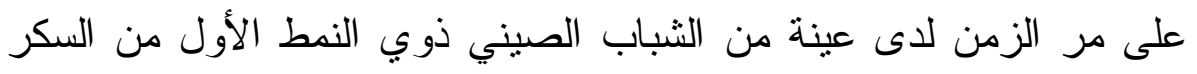




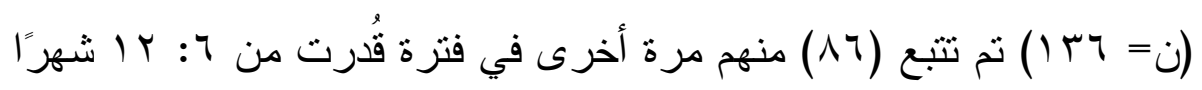

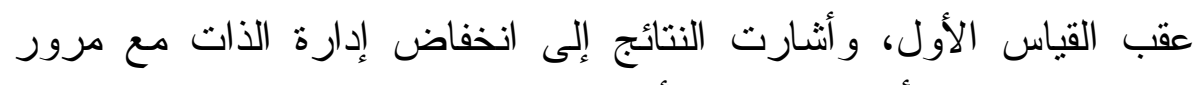

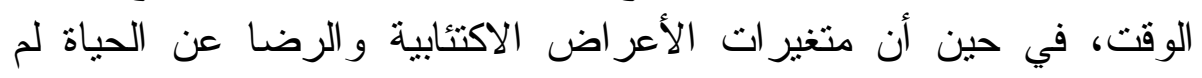

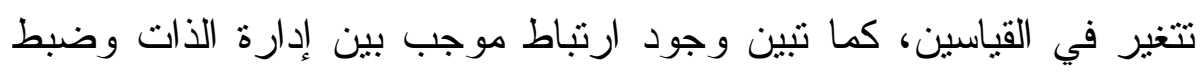

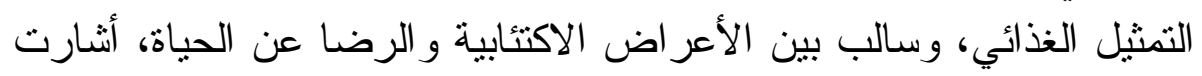

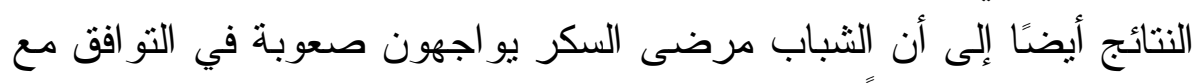

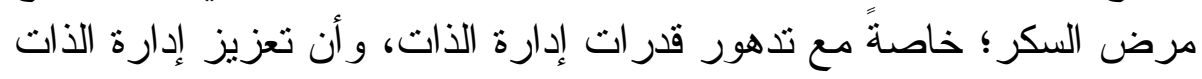

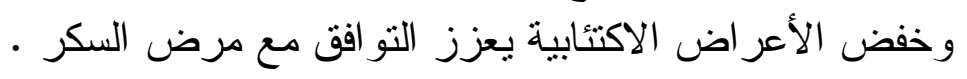

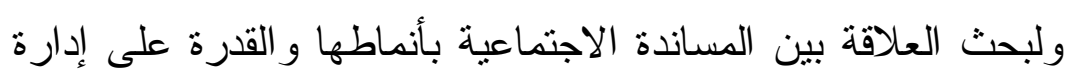

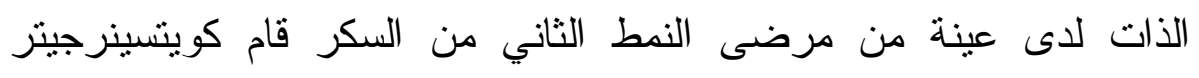
بتطبيق مقياسي المساندة الاجتماعية و إدارة

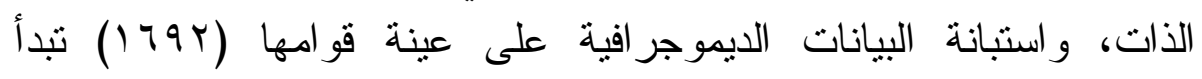

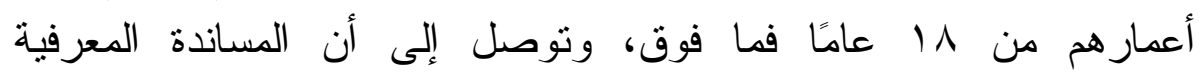

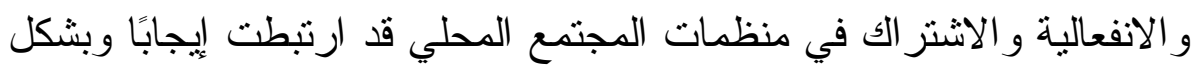

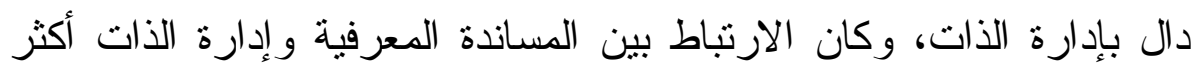

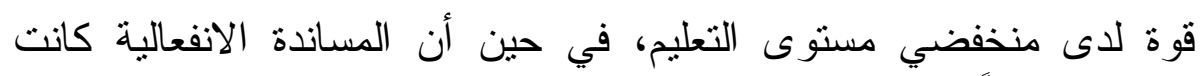

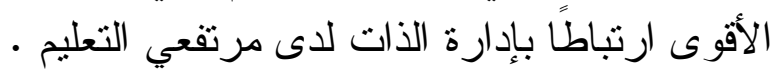

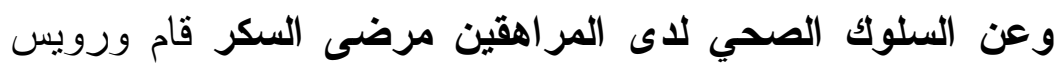

(Rorres, 1995)

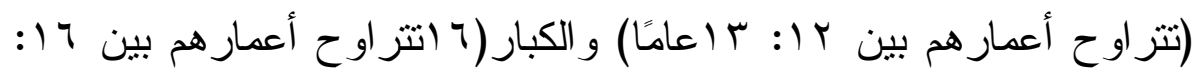

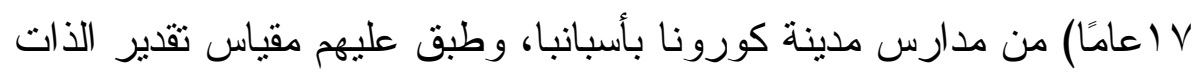
(Gordon, 1978)

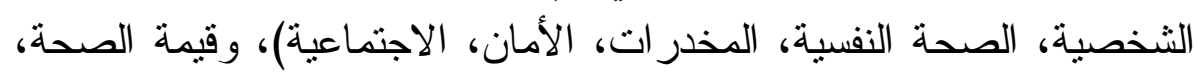

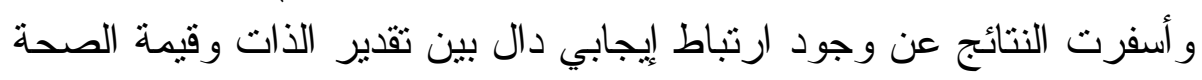
ومؤشر ات السلوك الصحي الإيجابي . ولبحث تأثير كل من تقدير الذات وقيمة الصحة في السلوك الصحي 
لاى المر اهقين، قام روثمان و آخرون (Rothman et al., 2008) بدر استهم

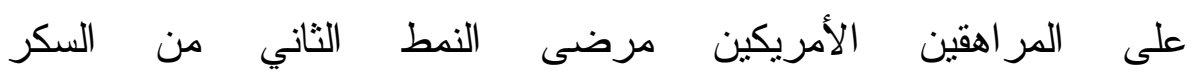

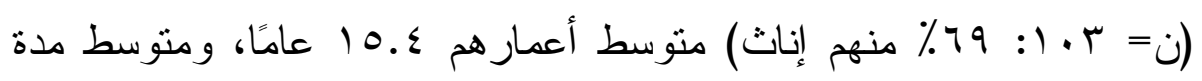

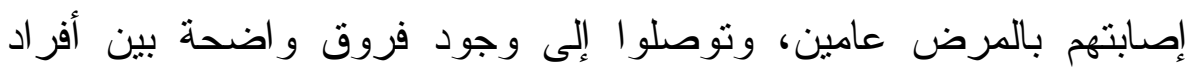

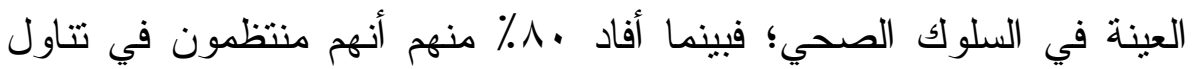

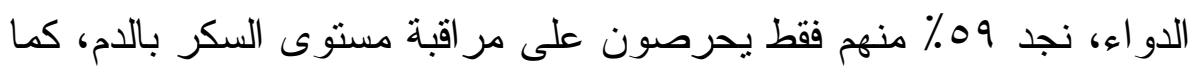

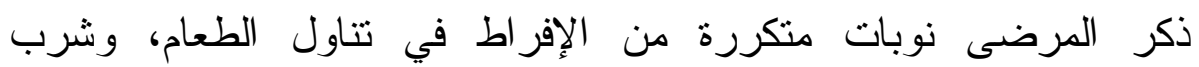

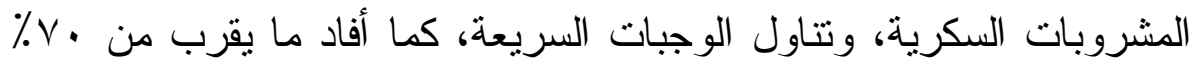

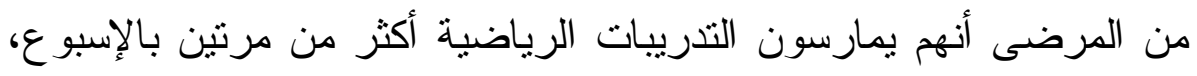

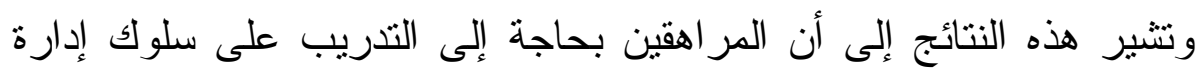

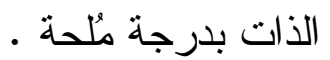

أما إدارة الأت وعلاثتها بالسلوك الصحي لاى المراهقين مرضى درى

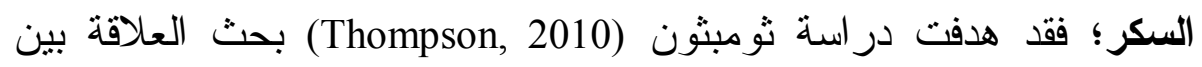

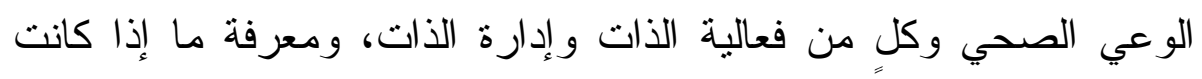

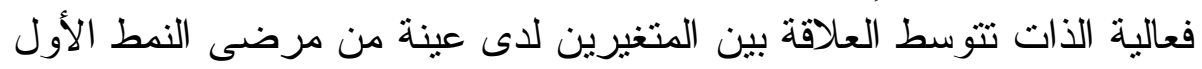

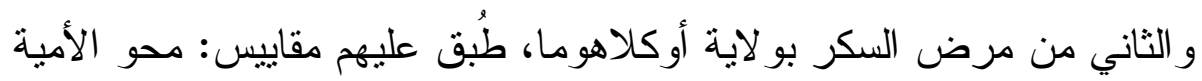

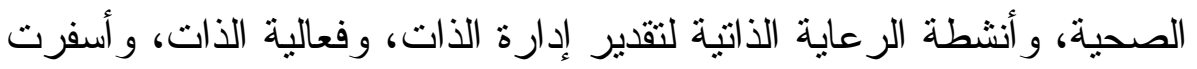

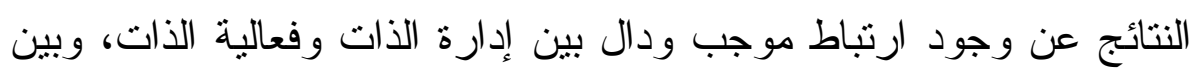

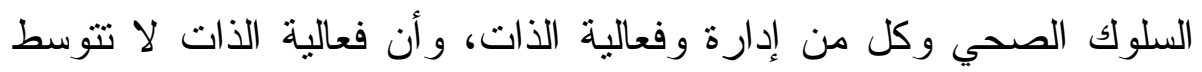
العلاقة بين إدارة الذات و الوعي الصحي ـ الصدات

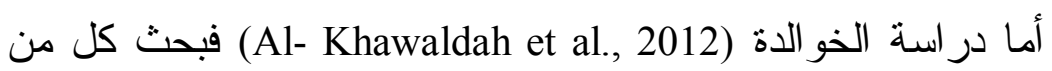
إدارة الذات وفاعلية الذات وعلاقتهما بضبط السكر بالدم لاى عينة قوامها

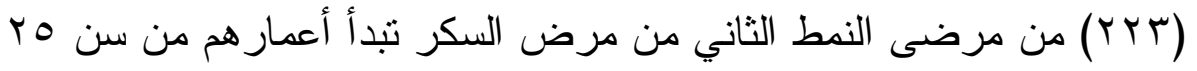

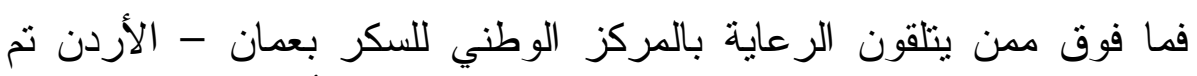

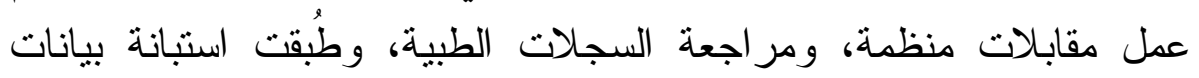


ديموجر افية ومقياسي فعالية الذات و الإدارة الذاتية، كما تم استخدام الهيموجلوبين Glycosylated hemoglobin كمؤشر لضبط السكر بالدم، وتوصلت النتائج إلى أن فعالية الذات و إدارة الذات يتتبأن بشكلٍ دال بنسبة السكر بالدم، وأن المرضى ذوي فعالية الذات المرتفعة قرروا وجود إداد إدارة ذاتية أفضل لسلوك النظام الغذائي، والرياضة، وفحص نسبة فئ السكر بالدم، ونتاول الأدوية .

وفيما يتعلق بتنمية إدارة الأات لاى المراهقين مرضى السكر نجد

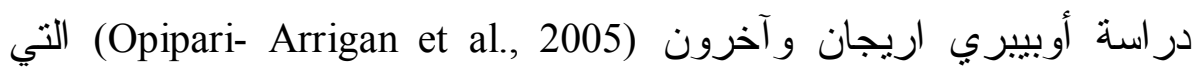
بحثت فاعلية تدخل قائم على مساعدة الأسرة في تتمية الإدارة الذاتية لمرض فرون

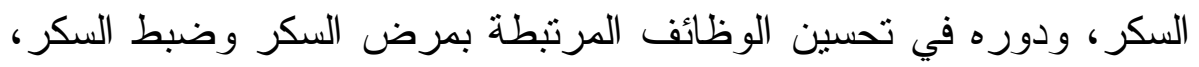

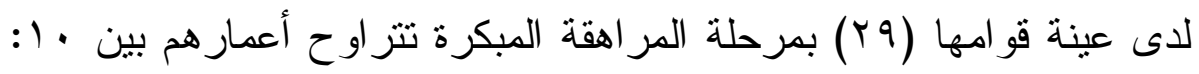
ـ ا عامًا و آبائهم، وتكون التدخل من 7 جلسات إسبوعية، كما تم تقدير معلوماتهر عن مرض السكر و التو افق مع المرض، و المسئولية عنه، ومعدل

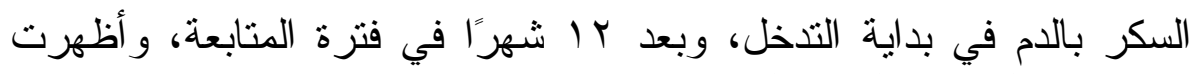

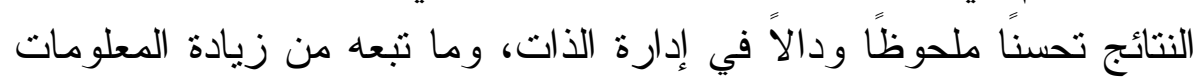
المرتبطة بالسكر و التو افق مع المرض، وكذللك المسئولية الثخصية. أما در اسة مولفانسي و آخرون (Mulvancy et al., 2010) فبحث فاعلية

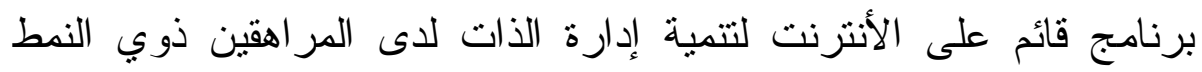

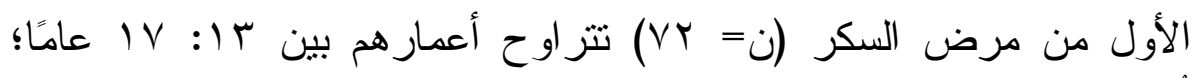

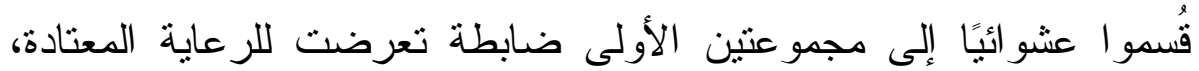

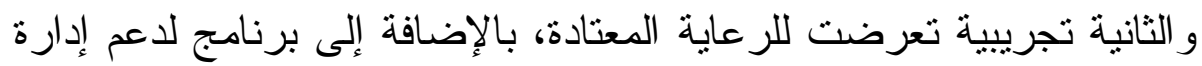

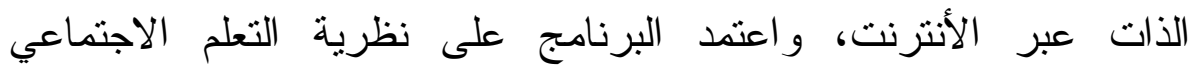

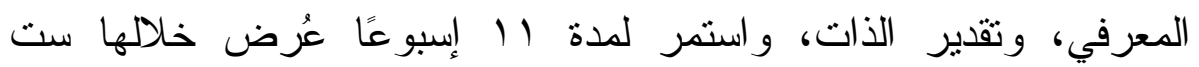
قصص باستخدام الوسائط المتعددة تصور العوائق النفسية و الاجتماعية لإدارة الذات (مثل ضغط الوقت- متطلبات التتافس - التردد) فضلاً عن النظريات 
المختلفة للتو افق وحل المشكلات، ومراحلها، كما تضمن التدريب التعرف على المشكلات التي تعوق إدارة الذات، و التدريب على كيفية مو اجهتها، وقد

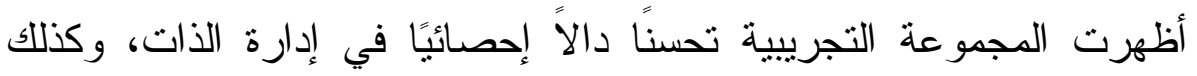
القدرة على حل المشكلات .

وفي ذات السياق سعت دراسة بو لاكلاك (Bulaclac, 2011) لتقييم

فاعلية برنامج تدخلي عبر الانترنت يهدف تتمية إدارة الذات لدى المر اهقين

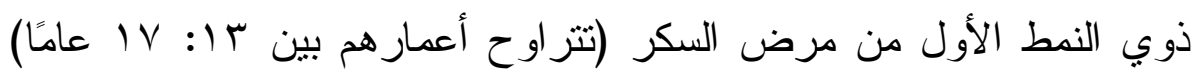

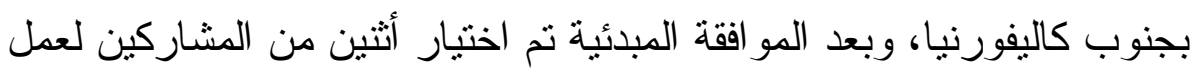
در اسة حالة لهم، و أسفرت النتائج عن فعالية التدخل القائم على تتمية إدارة الذات في دعم الشعور بالتحكم الذاتي وفعالية الذات في ضبط السكر لديهم في فترة انتقالهم من مرحلة الرعاية الو الدية، ونوصي هذه الدر اسة بإجر اء

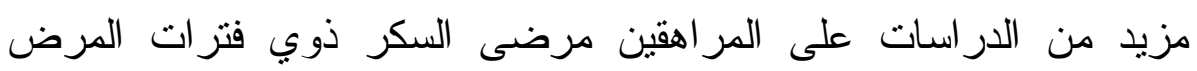
المختلفة و أنماط الخبرة المختلفة.

و لاختبار فاعلية نوعين من بر امج تتمية إدارة الذات في حدوث تحسن

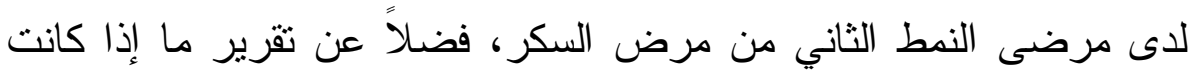
هناك فروق في فاعلية البرنامجين، اعتمد ماك جاون (Mc Gowan, 2015)

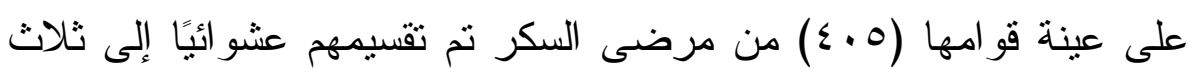

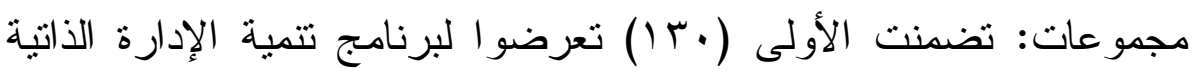

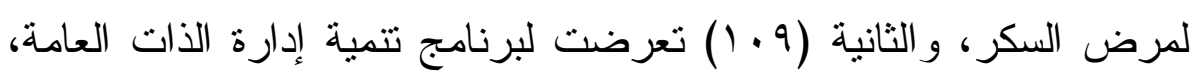
و الثالثة (Y Y I) ومثلت المجموعة الضابطة التي لم تتعرض لأية تدخل، وتم قياس مجموعة من المتغير ات التابعة بعد التذخل مباشرةً وفي القياس التتبعي بعد مُضي با شهرًا من التدخل، و أسفرت النتائج عن عدم وجود فروق دعن دالة إحصائيًا بين البرنامجين من حيث الفاعلية؛ حيث أسهم كليهما في حدوث

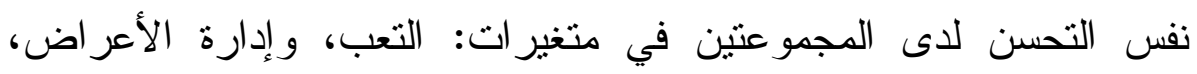
وفاعلية الذات المرتبطة بالمرض، و التو اصل مع الطبيب، ومقياس التمكين 
المرتبط بالسكر ، فضلاً عن متغير ضبط السكر بالدم . أما در اسة ماسيكامب (Musekamp et al., 2015) فاختبرت فاعلية

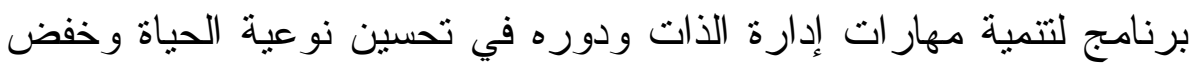

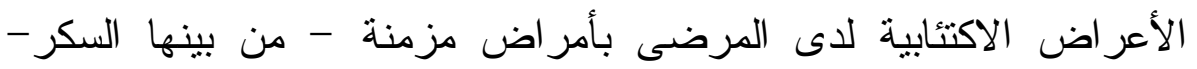
بألمانيا (ن= . مه)، طُبق عليهم مقاييس إدارة الذات، ونوعية الحياة، و الأعر اض الاكتئابية وبمقارنة القياسات القبلية و البعدية و التتبعية (بعد ثناثنة

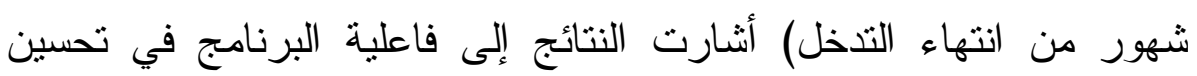
مهار ات إدارة الذات، وكذلك نوعية الحياة، وخفض الأعر اض الاكتئابية لدى

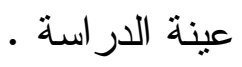

و لاختبار فاعلية برنامج تعليمي قائم على تتمية إدارة الذات في ضبط عملية التمثيل الغذائي لدى مرضى النمط الثاني من السكر اعتمد ساديجهان (Sadegghian et al., 2016) ضابطة (ن= r r ())، ورُوعي تحقيق التكافؤ بينهما في كل المتغيرات الصحية، وتم تقسيم المجموعة التجريبية لمجموعات صغيرة يتر اوح عدد

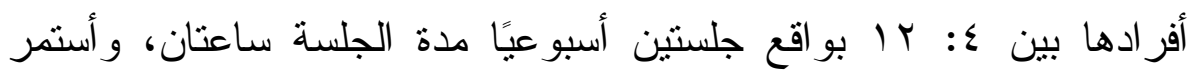
التدخل لمدة ستة أثنهر حدث بعدها تحسن دال لدى المجموعة التجريبية مقارنةً بالضابطة في ضبط عملية التمنيل الغذائي ومستوى النشاط البدني ومؤشر كتلة الجسم. تعقيب عام على الاراسات السابقة: من خلال استقر اء وتحليل الدر اسات السابقة نخلص إلى مأعى ماليلي:

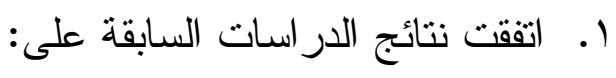
أ. أهمية متغير إدارة الذات لدى المر اهقين مرضى السكر ؛ إذ أنه يرتبط بارتفاع معدلات كل من الرفاهة النفسية، وفاعلية الذات، ونوعية الحياة

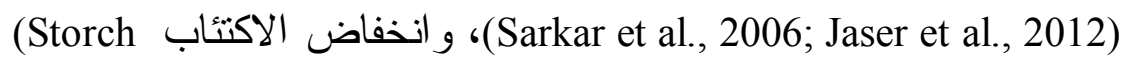
.et al, 2006; Gramm \& Nieboer, 2012) 
ب. افتقار المر اهقين مرضى السكر لمهار ات إدارة الذات؛ الأمر الذي يعزز

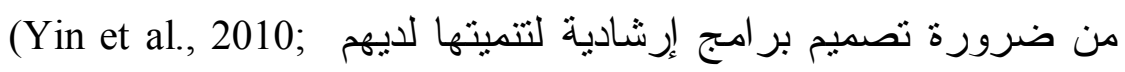

.Gua et al., 2015)

ج. أهية تتمية إدارة الذات لدى مرضى السكر ؛ خاصةً المر اهقين منهم؛ لها

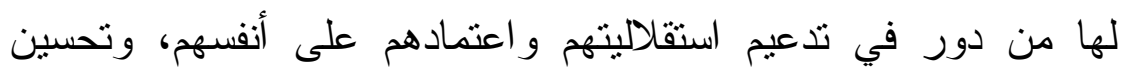

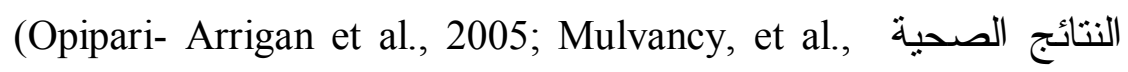
- 2010; Bulaclac, 2011) د. فاعلية البر امج الإرشادية في نتمية إدارة الذات لدى المر اهقين مرضى (Mc)

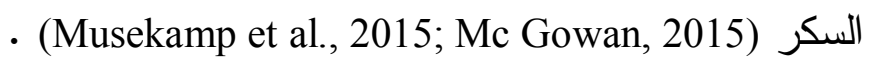
ه.وجود ارتباط موجب بين إدارة الذات و السلوك الصحي لدى المر اهقين

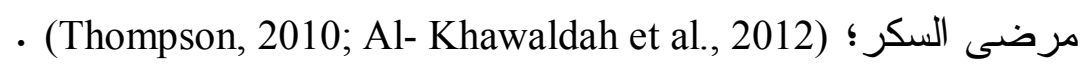
و · وجود ارتباط موجب بين إدارة الذات ومؤشرات تحسن الصحة البدنية،

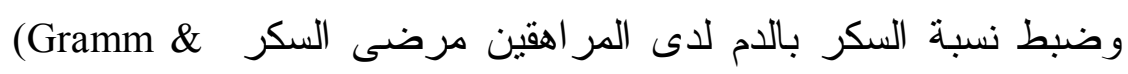
.Nieboer, 2012; Gua et al., 2015) ز. وجود فروق بين المراهقين مرضى السكر بصدد مدى انتظامهم في :لإي

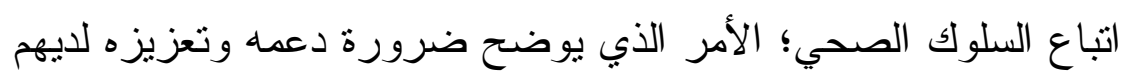
. (Rorres, 1995; Rothman et al., 2008) r. تباينت نتائج الدراسات السابقة بشأن علاقة إدارة الذات بفترة الإصابة

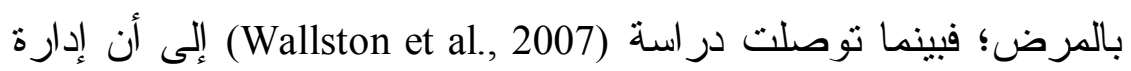

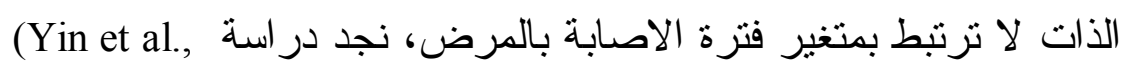

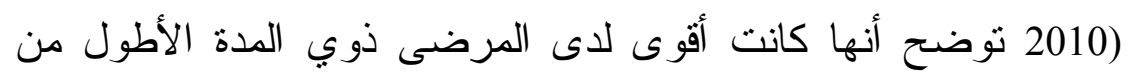
المرض، و الذين يستخدمون الأنسولين كعلاج.

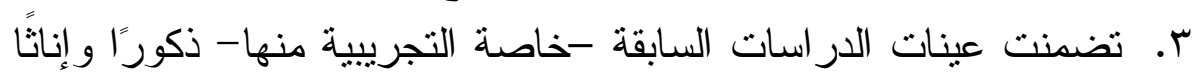

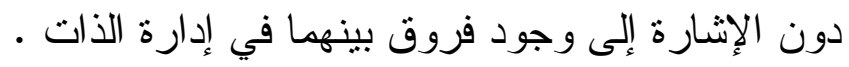

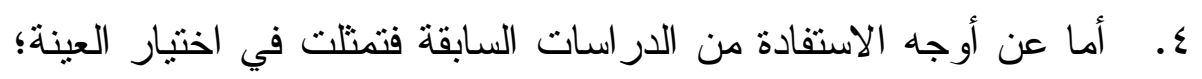


حيث جاءت من المر اهقين ذكورًا و إناثًا، كما ظهرت أوجه الاستفادة في

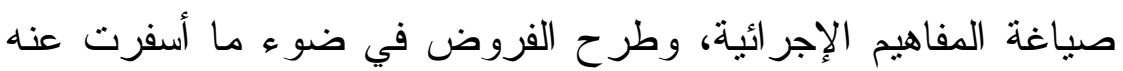

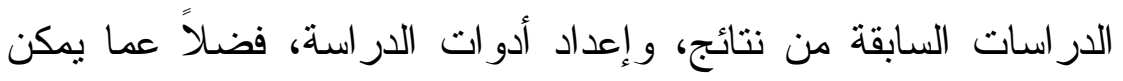
استخلاصه من تعزيز ات للنتائج عند مناقتنها لاحقًا.

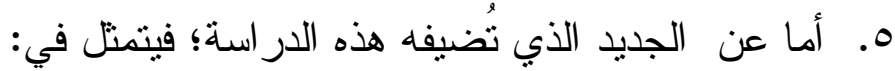

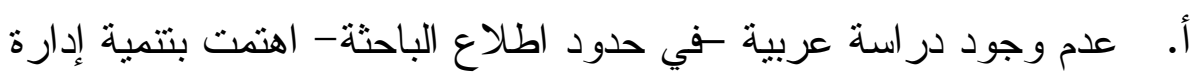

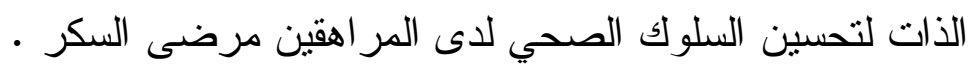

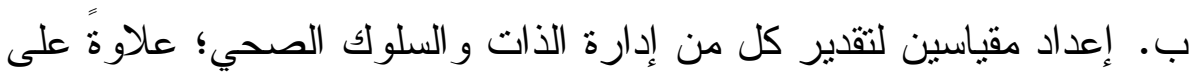
تصميم برنامج لتنمية إدارة الذات لدى المر اهقين مرضى الديز السكر . فروض الار اسة: في ضوء نتائج الدر اسات السابقة و الأطر النظرية المختلفة فإن هذه الدر اسة تسعى للتحقق من الفروض الآتية؛ ا. بيتحسن أداء المجموعة التجريبية من المراهقين مرضى السكر على

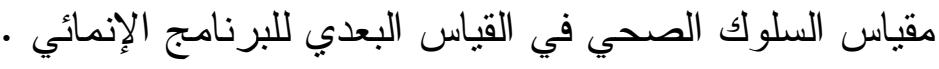

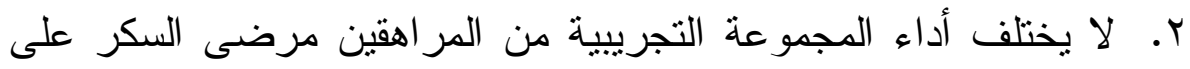
مقياس السلوك الصحي باختلاف القياسين البعدي و التتبحي (بعد شهر

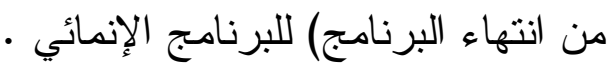
منهج الدر اسة و إجراعاتها: منهج الدر اسة:

اعتمدت الدراسة على المنهج التجريبي - للكثف عن فاعلية برنامج قائم على تتمية إدارة الذات في تحسين السلوك الصحي لدى عينة الدر اسة من المر اهقين مرضى السكر -؛ و استخدمت التصميم التجريبي ذي المجمو عة التهين الو احدة؛ وذلك لصعوبة استخدام التصميم التجرييي ذي المجموعتين لتعذرّر تحقيق التكافؤ بين المجموعتين التجريبية و الضابطة في كل المتغيرات التي 
من شأنها التأثير على المتغير التابع (السلوك الصحي) من قبيل نسبة السكر ، ونائ

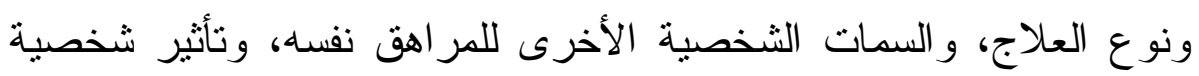

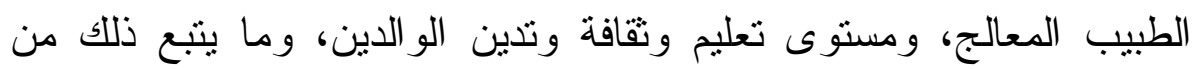

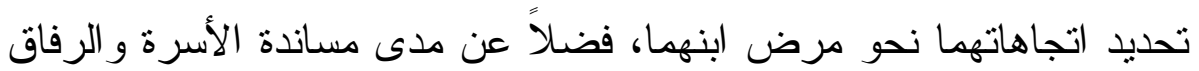

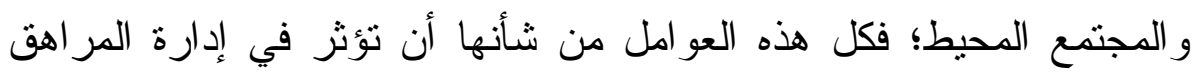

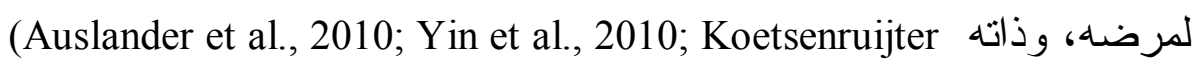
et al., 2016

\section{إجر اعات الار اسة وتثمل:}

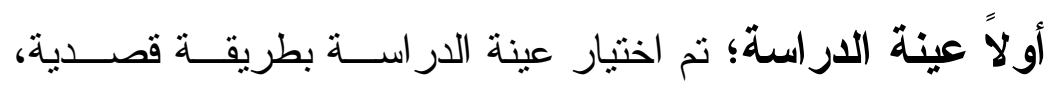
وتضمنت المجمو عتين الفرعيتين التاليتين:

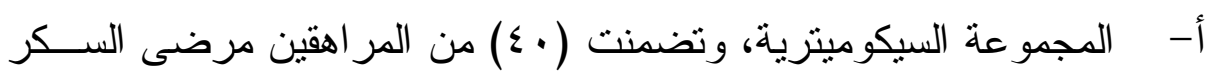

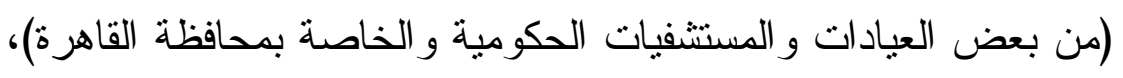

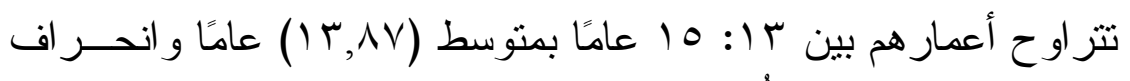

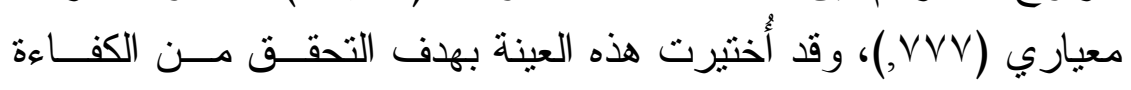

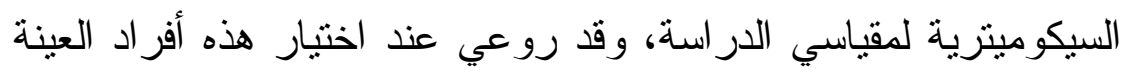

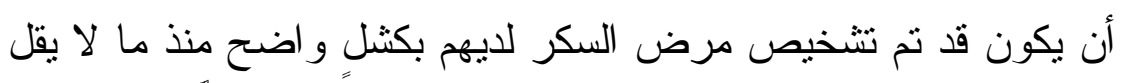

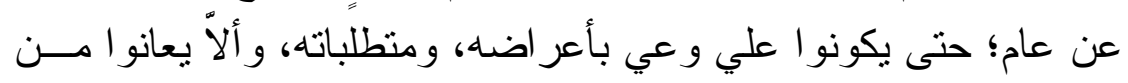

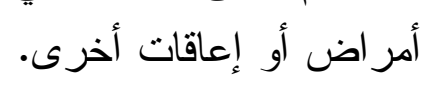

ب- - المجموعة الأساسية وتضدنت (^) ثمانية مر اهقين (0 ذكورًا، م إناتًا)

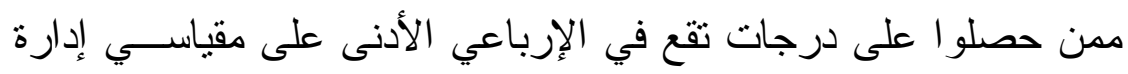

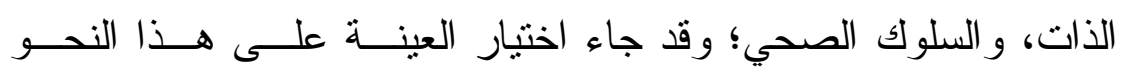

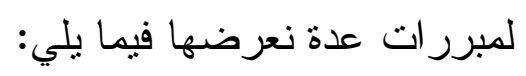

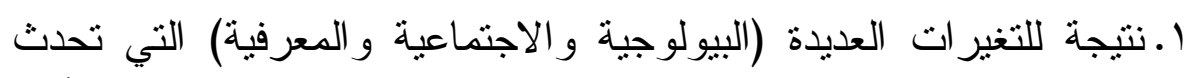

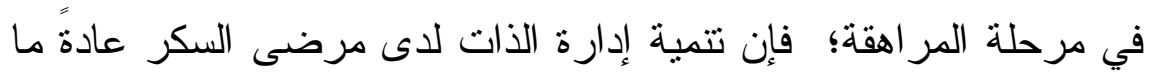

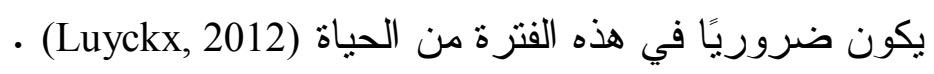


r. إن المر اهقين مرضى السكر في خطر متز ايد للمعاناة من مشكلات رعاية

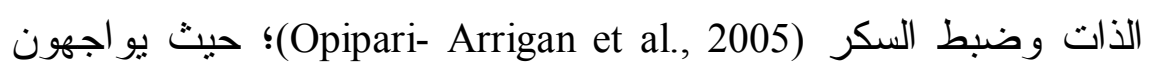

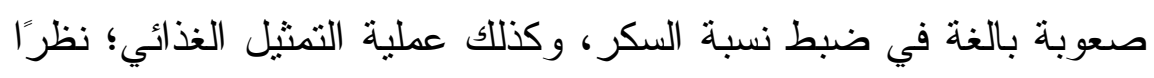

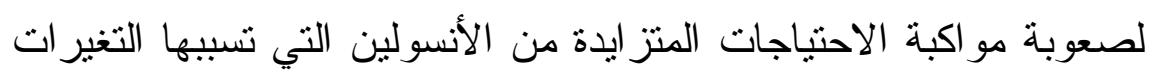

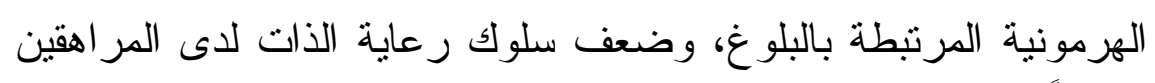

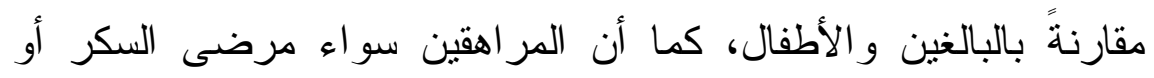

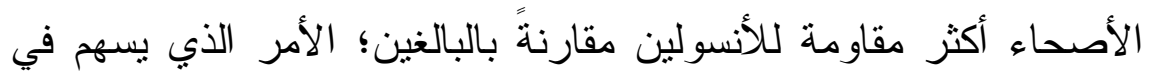

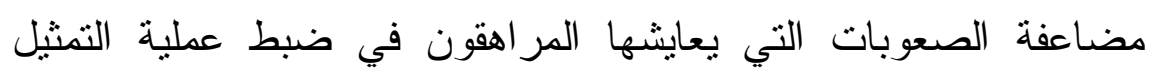

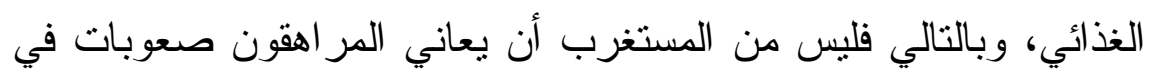

ضبط مرض السكر بشكل يفوق الأطفال و البالغين (Verchota, 2014).

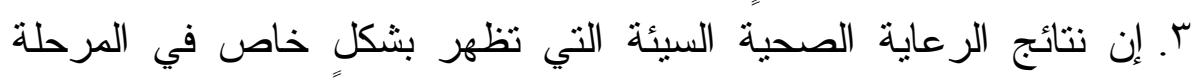

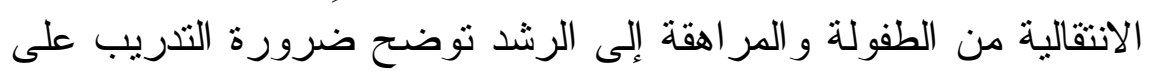

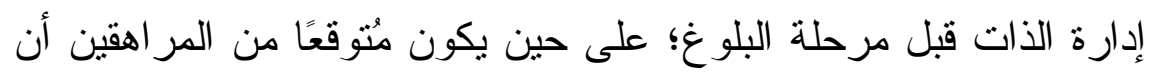

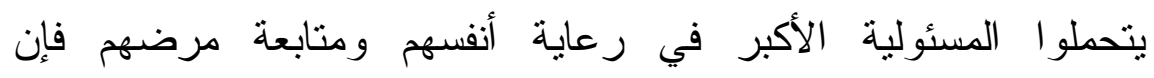

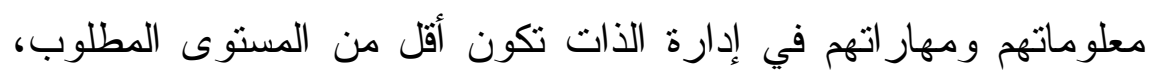

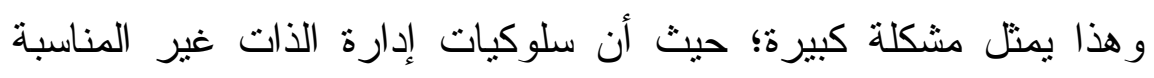

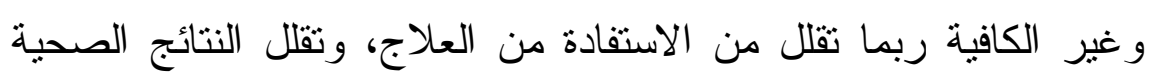

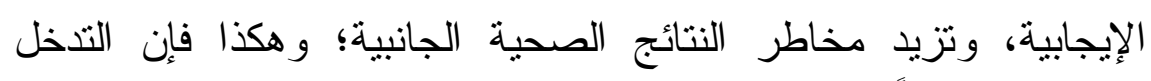

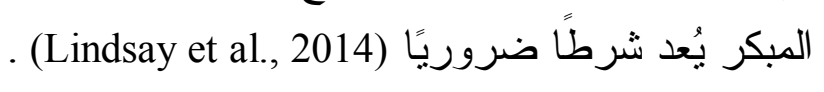
ثانيًا أدوات الدراسة؛ لتحقيق أهداف الدر اسة نم اعداد الداد الأدوات التالية:

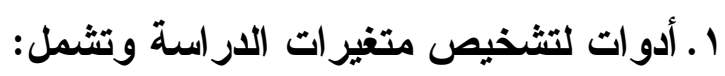

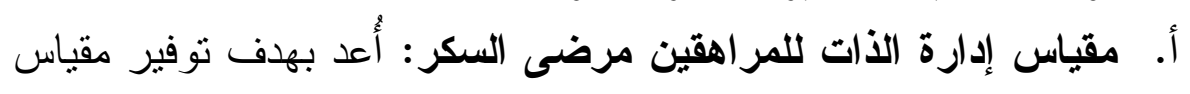

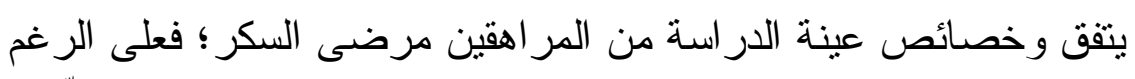

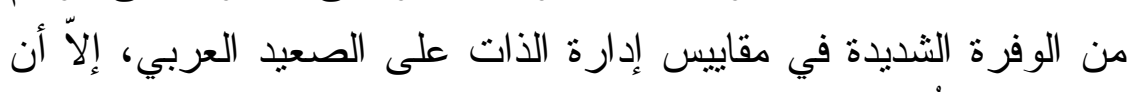

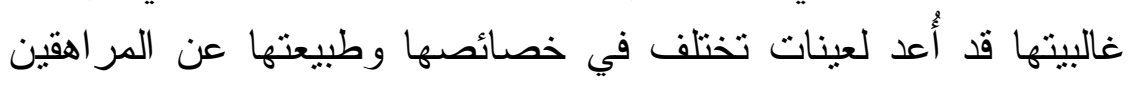


مرضى السكر؛ وفي ضوء ما تقدم تمت مر اجعة الأطر النظرية المتعلقة

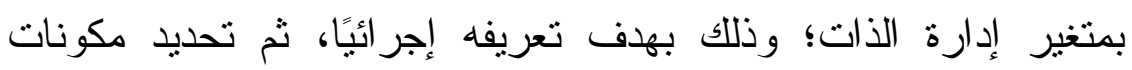

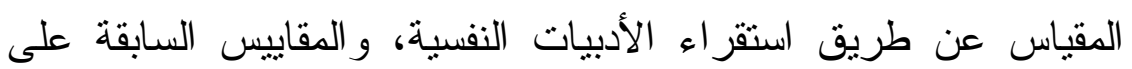

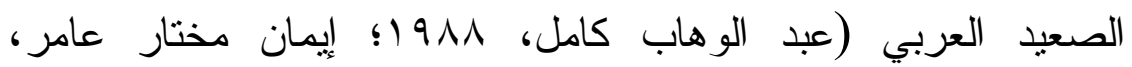

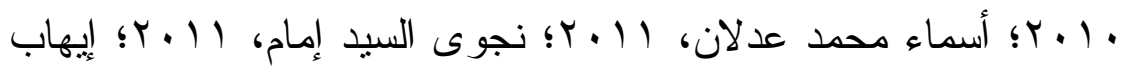

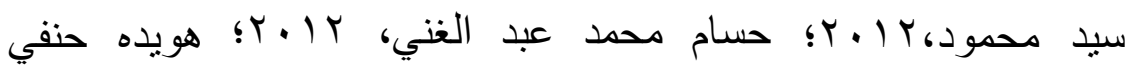

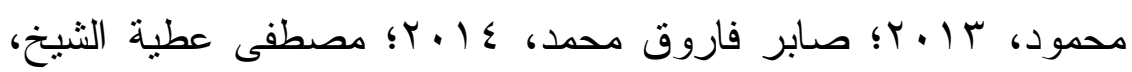

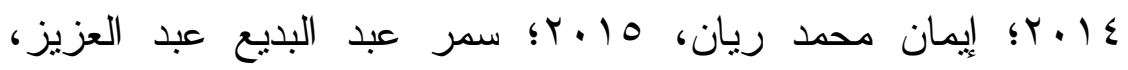
10

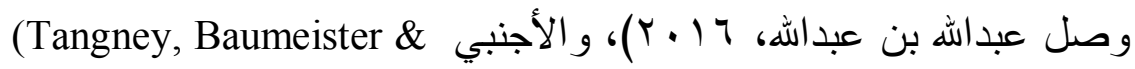
Boone, 2004; Schuurmans, Steverink, frieswiikn et al., 2005; Wallston et al., 2007; Mezo, 2009; Shakibazadeh et al., 2012; Xue \& Sun, 2012; Zhang, Wang, Li, Cai, Zhang, Wang \& Wang, 2013; فضلا عن تطبيق استبانة Klassen, et al., 2015; Lee, et al., 2016) مفتوحة على مجموعة من أساتذة علم النفس، وكذلك الو الدين و القائمين

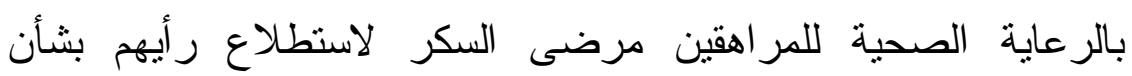

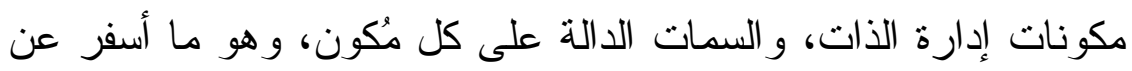

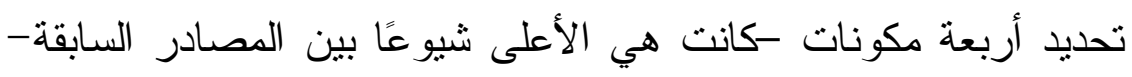
تمثلت في: مر اقبة، وتوجيه، وتقييم، وتعزيز الذات، وبعد تحديد مكونات

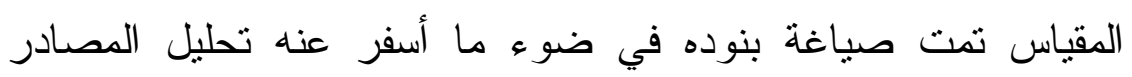
السابقة، وقد روُعي في الصباغة التتوع بين السلب و الإيجاب، و الدقة

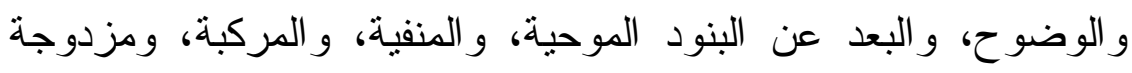

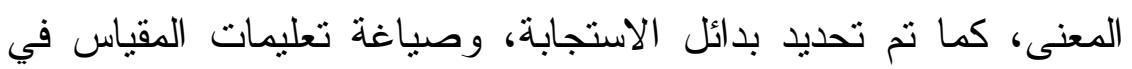
صورة واضحة وملائمة للعينة، وتضمن المقياس في صورته الأولية

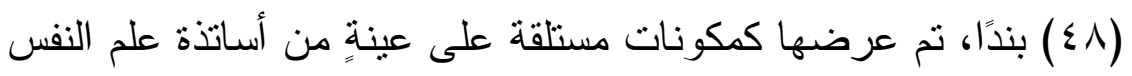

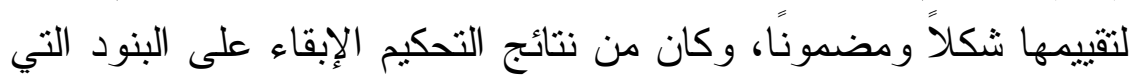

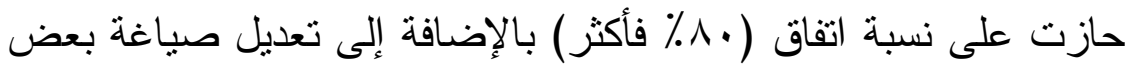


البنود، ونم تجريب المقياس من خلال تطبيقه في صورته النهائية على عينة استطلاعية (• (1 من المر اهقين مرضى السكر) للاطمئنان لوضوح

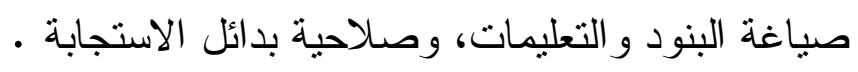
الكفاعة السيكومترية للمقياس؛ وتشمل: الثبات؛ للتحقق من ثبات

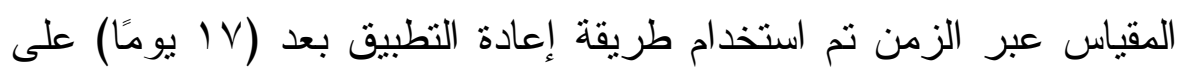

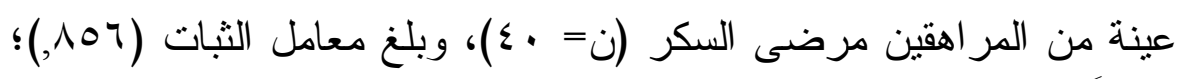

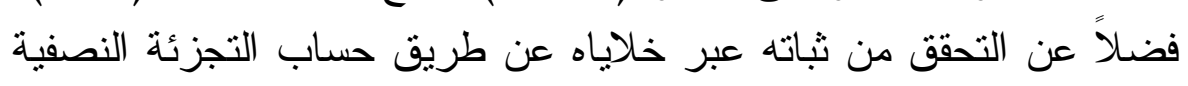

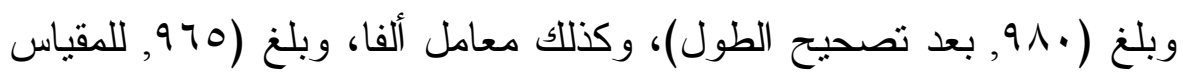

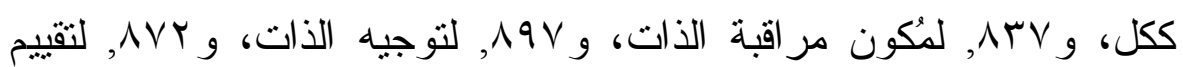

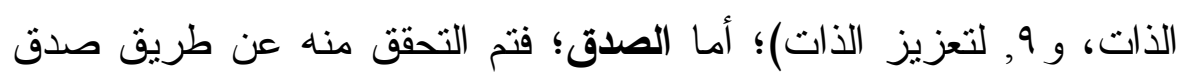
المحكمين، وسبقت الإشارة إليه، وكذلك الصدق المرثبط بالمحك؛ حيث حُسب معامل الارتباط بين درجات عينة التحقق من الكفاءة السيكوميترية (ن= • §) على المقياس ودرجاتهم على مقياس فاعلية الذات (أحمد حسانين

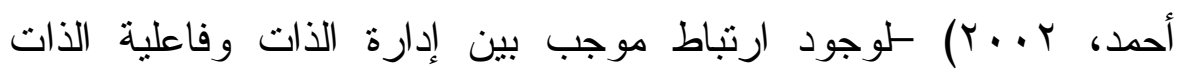
(Sarkar, et al., 2006; Al- Khawaldah, et al., 2012)

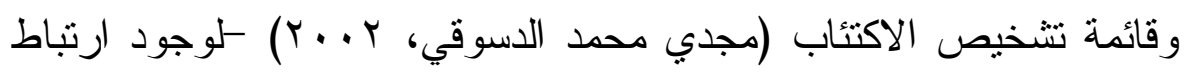

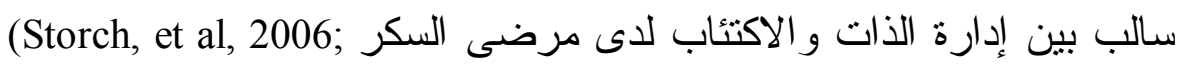
Gramm \& Nieboer, 2012) من قدرة المقياس على التمبيز - باعتبار ها مؤشرًا على الصدق - عن طريق

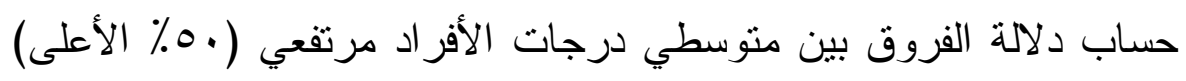

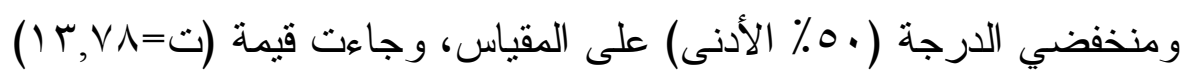

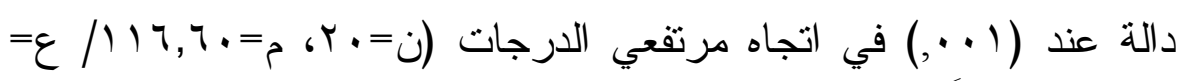

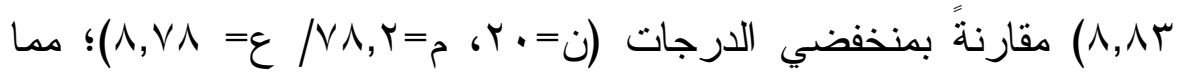
يبر هن على صدق المقياس. ب. مقياس السلوك الصحي للمراهقين مرضى السكر: على الرغم 
من وفرة مقاييس السلوك الصحي على الصعيد العربي؛ إلاّ أن غالبيتها قد

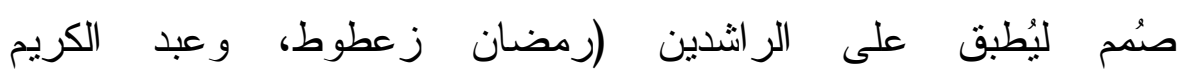

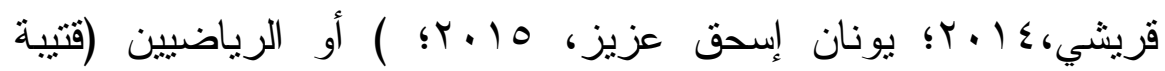

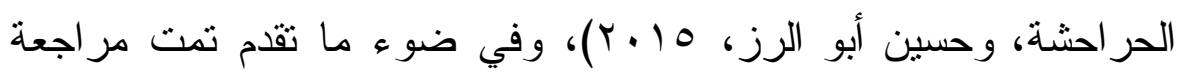

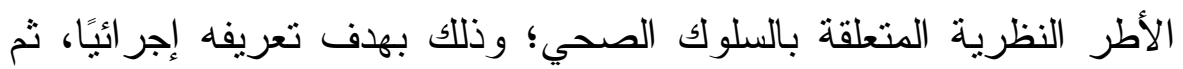

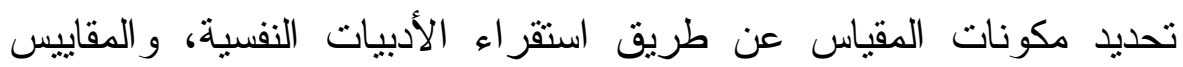

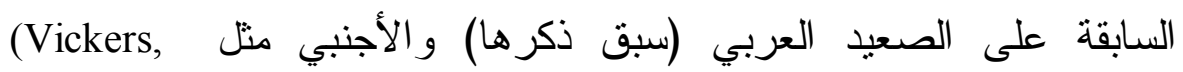
Conway \& Hervig, 1990; Hooker \& Kaus, 1994; Chen, Wang, Yong \& Liou, 2003; Shin, 2010; Moreno, Kelley, Landry, Paasch, Terlecki, فضلاً عن تطبيق Johnston \& Foreyt, 2011; Dosedlova, et al., 2015) استبانة مفتوحة على مجموعة من أساتذة علم النفس، وكذلك القائمين على ألى

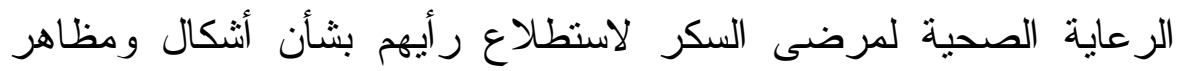

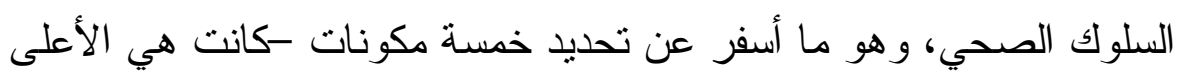

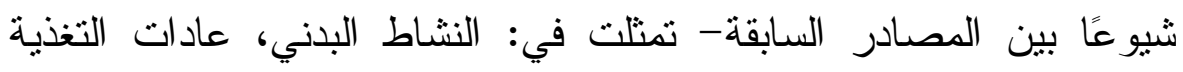
و النوم، و الرعاية الذاتية الصحية، والإجراءات الصحية الوقائية، وتعزيز

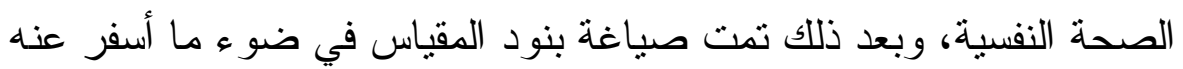

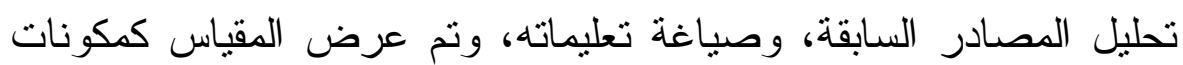

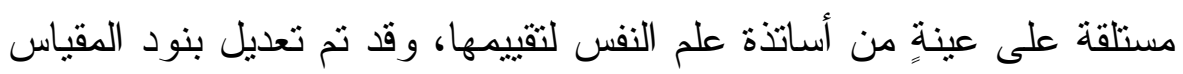
في ضوء توصيات المحكمين، بعد ذلك تم تجريب المقياس من خلال تطبيقه

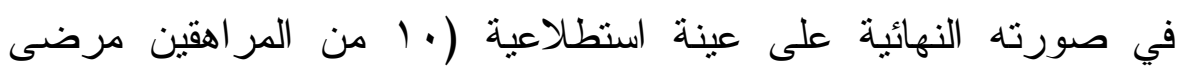

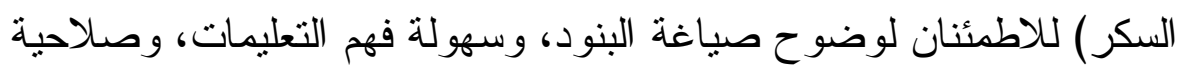

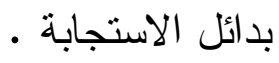

الكفاعة السيكومترية للمقياس؛ وتثمل: الثبات؛ ونم التحقق منه ثبات

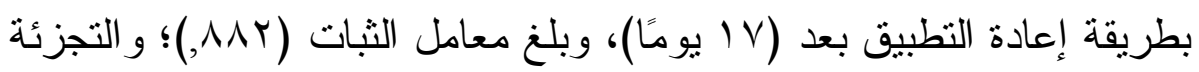

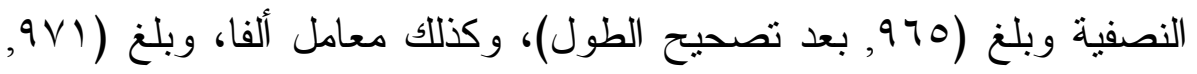

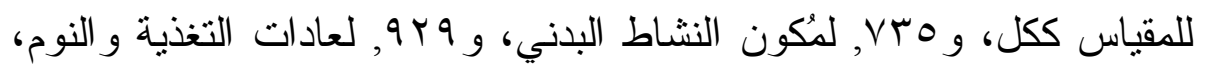




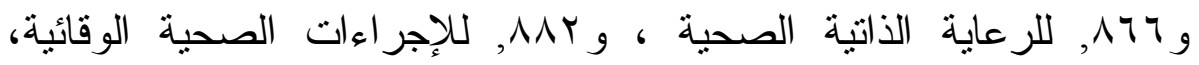

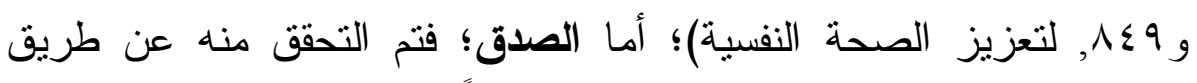
صدق المحكمين، وسبقت الإشارة إليه، علاوةً على ما تقدم تم التحقق من

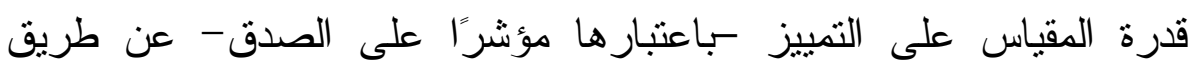

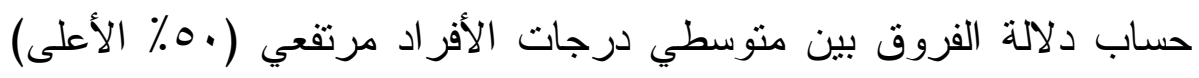

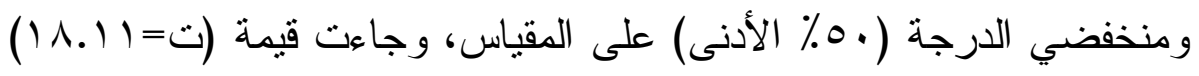

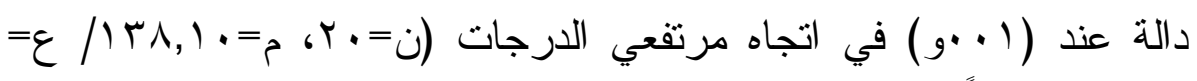

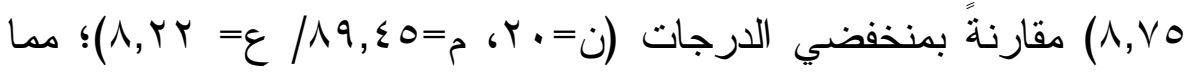
يبر هن على صدق المقياس.

أدوات إنمائية، وتمثلت في برنامج إنمائي لتتمية إدارة الذات للمر اهقين مرضى السكر ، ويُعرف هذا البرنامج بأنه "خطة ارشادية معرفية

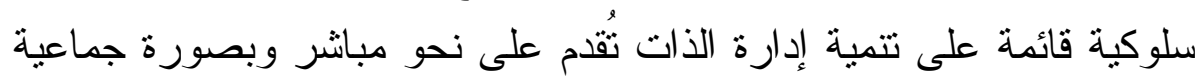
لعينة من المر اهقين مرضى السكر بهدف تحسين السلوك الصحي لديهم" . ولإعداد هذا البرنامج تم اتباع الخطوات التالية:

1. الإطلاع على الأطر النظرية و الدراسات السابقة؛ لبناء تصور عام عن

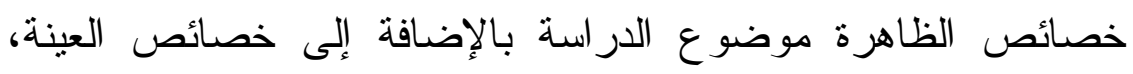

وتكوين قاعدة عريضة يتم في ضو عها انتقاء أنثطة البرنامج وفنياته . r. مر اجعة الأدبيات السيكولوجية المعنية بالإرشاد النفسي للإستفادة منها في

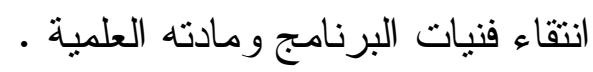
r. استقر اء وتحليل الدر اسات السابقة التي هدفت تتمية إدارة الذات، وتحسين السلوك الصحي، وقد أفضت هذه المرحلة إلى عدة نتائج تتمثل فيما يلي: أـ ـثة در اسات أجنبية تتاولت متغيري الدراسة - إدارة الذات، و السلوك الصحي - - بشكلٍ عام، وإن كانت الدر اسات الوصفية تفوق الدر اسـات الإرشادية. 
بـ أثنارت نتائج الدراسات الأجنبية إلى أهمية تتمية إدارة الذات لدى

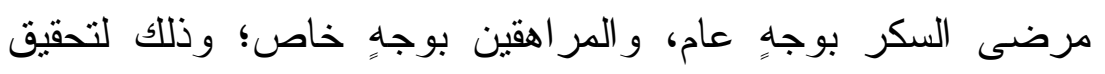

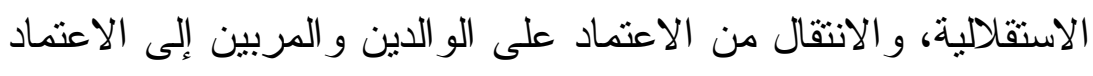

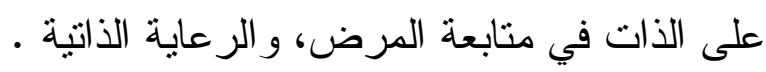

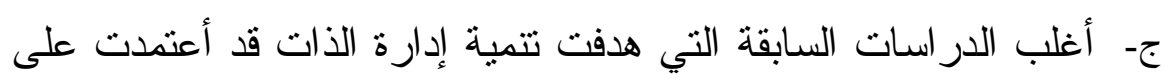

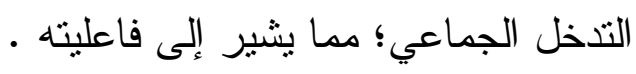

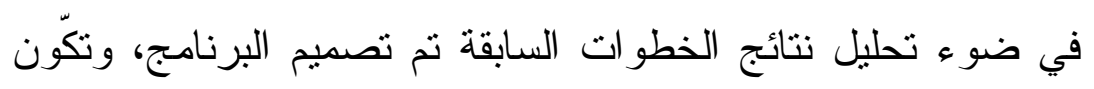

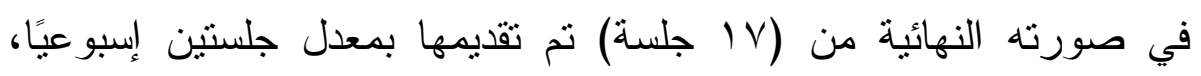

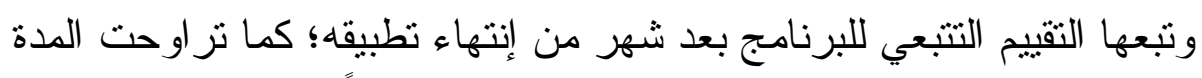

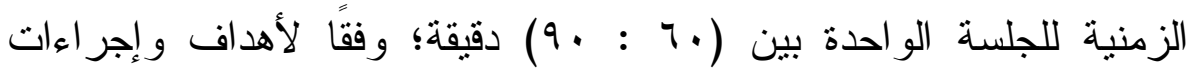

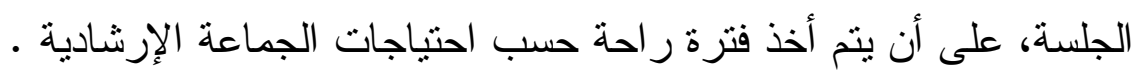

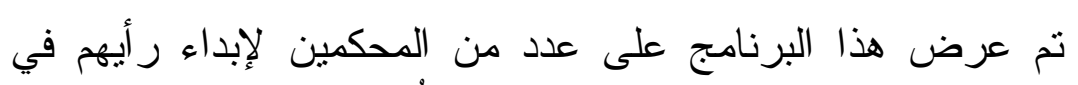

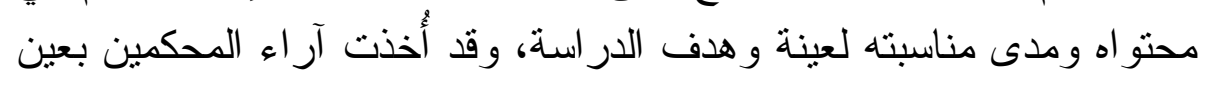

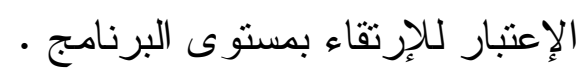

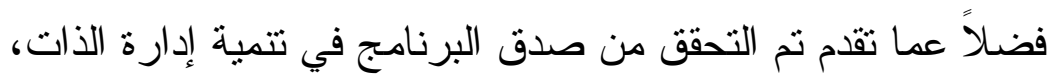

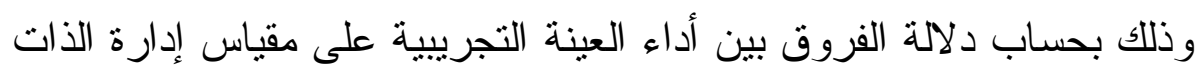

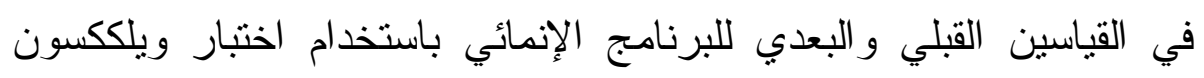

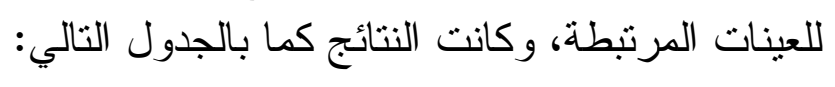

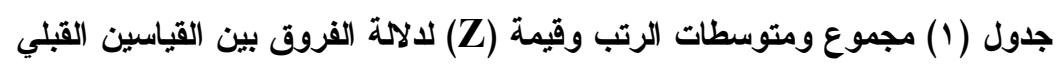
و البعدي للمجموعة التجريبية على مقياس إدارة الذات التئ

\begin{tabular}{|c|c|c|c|c|c|}
\hline الدلالة & 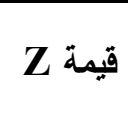 & الرتب & الرتبوع & عدد الرتب & آلثيبم الاحصائية \\
\hline \multirow{2}{*}{, .1} & \multirow{2}{*}{$r, O Y T-$} & $\xi, \infty$ & $r 4, \cdot \cdot$ & الرتب الموجبة = & \multirow[t]{2}{*}{ إدارة الذات } \\
\hline & & صفر & صفر & الرتب السالبة = صفر & \\
\hline
\end{tabular}

يتضح من القيم المُدونة بالجدول (1) وجود فروق دالة إحصائًًا بــين 
القياسين القبلي و البعدي للعينة التجريبية على مقياس إدارة الذات؛ حيث بلغت

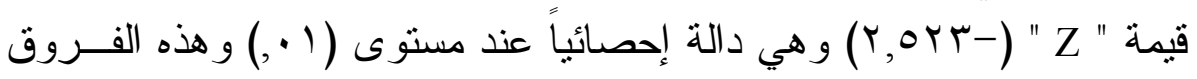

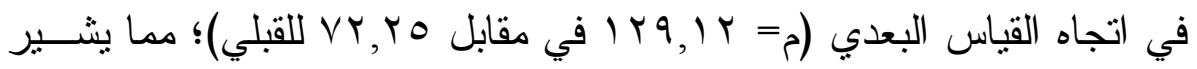

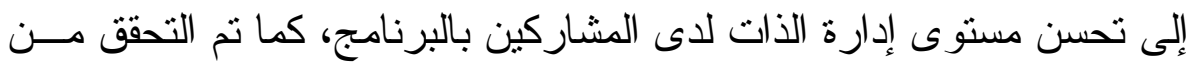

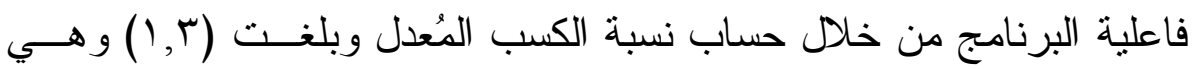

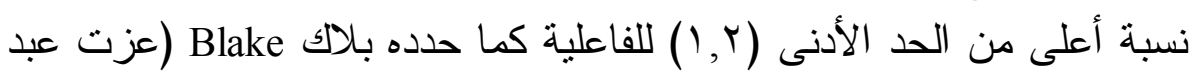

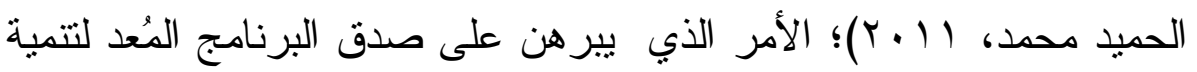

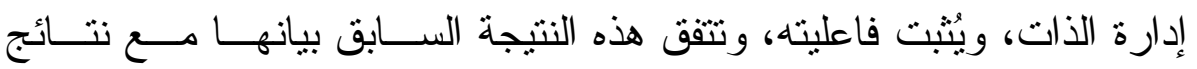

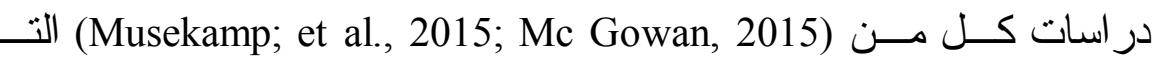
أثنارت إلى فاعلية البر امج الإرشادية في تتمية إدارة الذات لدى المــر اهقين

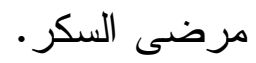

ثالثًا تطبيق أدوات الدر اسة: تم تطبيق أدوات الدر اسة على النحو التالي: أولاً: تطبيق مقياسي إدارة الذات و السلوك الصحي على العيق العينة

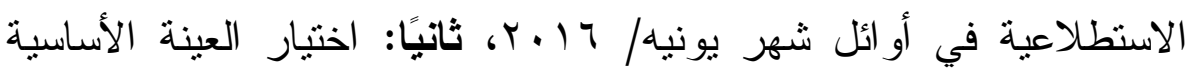

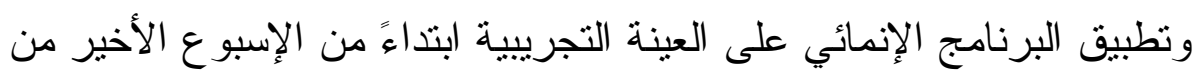

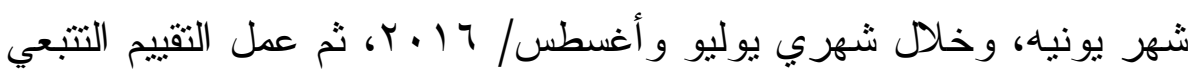
للبرنامج بعد شهر من انتهاء تطبيقه.

رابعًا الأساليب الإحصائية: في ضوء الوصف الإحصائي لمتغيرات

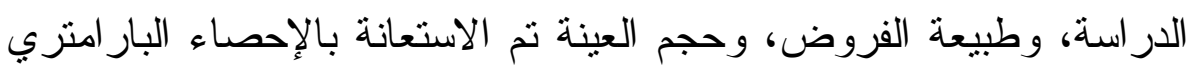

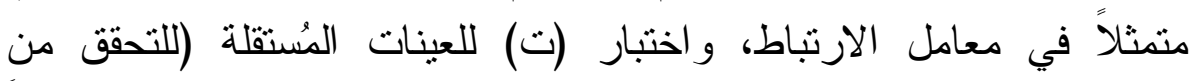
الكفاءة السيكوميتزية للمقياسين)، كما أستعانت بالإحصاء الإبار امتري مُّنثاً في اختبار ويلككسون للعينات المرتبطة (للتحقق من صحة فرضي الدراسة).

\section{تنائج الدر اسة ومناقثتّها:}

الفرض الأول، ونصه "يتحسن أداء المجموعة التجريبية من المر اهقين مرضى السكر على مقياس السلوك الصحي في القياس البعدي للبرنامج 
الإنمائي"، وللتحقق من صحة هذا الفرض عُولجت استجابات عينة الدراسة التجريبية على مقياس السلوك الصحي باستخدام اختبار ويلككسون للعينات المرتبطة، وأسفر عن النتائج المبينة بالجدول التالي : علئي جدول (r) مجموع ومتوسطات الرتب وقيمة (Z) لالالة الفروق بين القياسين القبلي

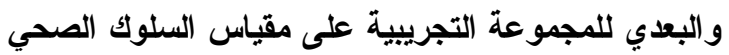

\begin{tabular}{|c|c|c|c|c|c|}
\hline الدلالة & قيمة Z & متوسط & الرتب & عدد الرتب & \\
\hline \multirow{2}{*}{,+1} & \multirow{2}{*}{$r, \Delta r \leqslant-$} & $\varepsilon, 0$. & $\overline{r q, \cdots}$ & الرتب الموجبة = ^ & \multirow{2}{*}{ السلوك الصحي } \\
\hline & & صفر & صفز & الرتب السالبة = صفر & \\
\hline
\end{tabular}

بمر اجعة القيم الواردة بالجدول (r) يتبين لنا تحقـق صــــة هــــا الفرض؛ حيث بلغت قيمة " Z " لدلالة الفروق بين القياسين القبالـي و البعــدي

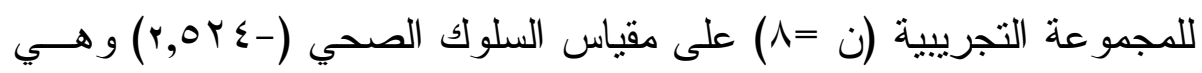

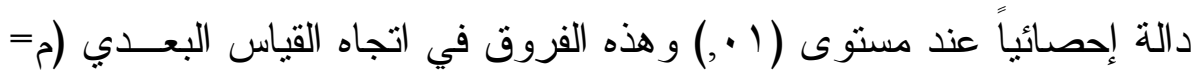

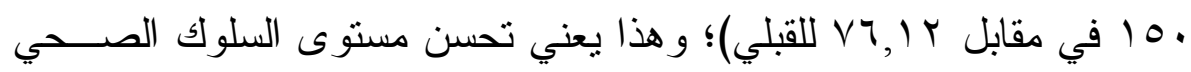

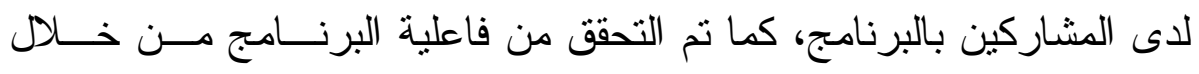

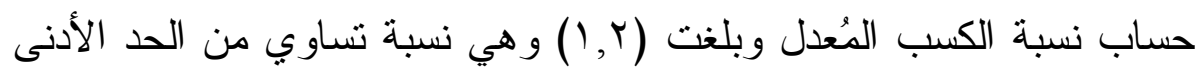

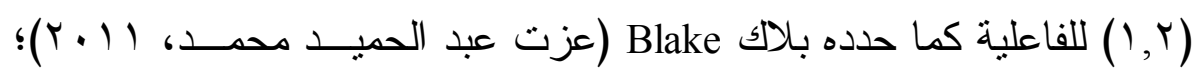
الأمر الذي يُتبت فاعليه البرنامج في تحسين السلوك الصحي. باعي. يتضح مما تقدم تحسن أداء العينة التجريبية علــى مقيــاس (الســلوك كـ

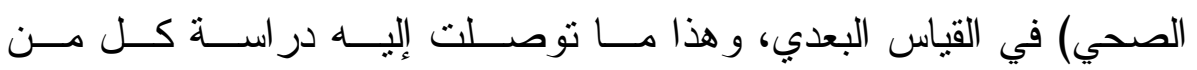
التي أثنارت إلى وجـــود (Thompson, 2010; Al- Khawaldah et al., 2012) ارنباط موجب بين إدارة الذات و السلوك الصحي لدى المــر اهقين مرضــى

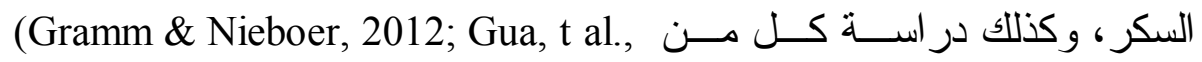
(2015، التي أيدت وجود ارتباط إيجابي بين إدارة الذات ومؤشر ات تحسـن

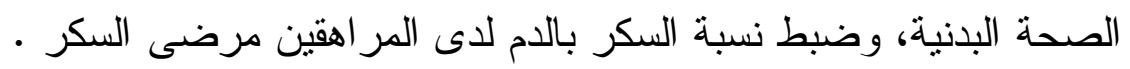


مناقشة النتائج: يمكن مناقشة نتائج هذا الفــرض علــى النحــو التالي:

أولاً ما أثنارت إليه الأدبيات النفسية و أيدته الدر اسات السابقة من وجود علاقة موجبة وقوية بين إدارة الذات و السلوك الصحي، وأن تتمية إدارة الذات من شأنه أن ينعكس على تحسن السلوك الصحي لدى الأفر اد؛ فمفهوم إدارة الذات من المفاهيم النفسية العصرية التي لها دور إيجابي وفعَّال في لني تتظيم حياة الفرد؛ فالثخص القادر على إدارة ذاته هو الذي استفاد من مو اهبه

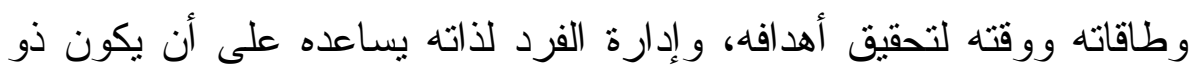

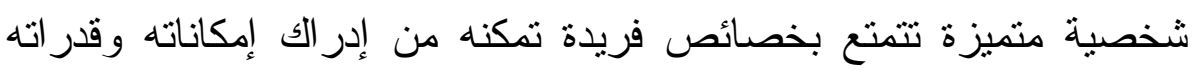

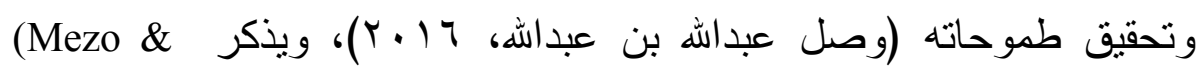

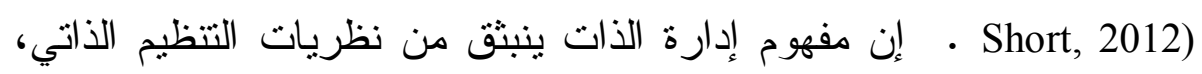
وقد أصبحت إدارة الذات قضية جو هرية في مجالات عدة مثل تعزيز الصحة

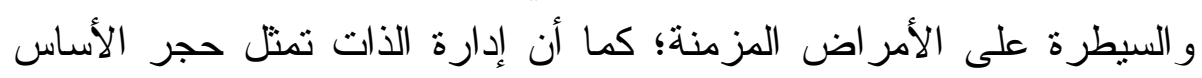
في رعاية مرضى السكر (Sarkar et al., 2006)، وتهدف بر امج تتمية إدارة الذات إلى تحسين مهار ات المريض في إدارته لمرضه المزمن عبر الحياة اليومية فمن المُفترض أن تحسين إدارة الذات بحسن بدوره في النتائج بعيدة المدى مثل نو عية الحياة (Musekamp et al., 2015)

إن المرضى الذين يعانون من أمر اض مزمنة منل السكر يحتاجون إلى دأى

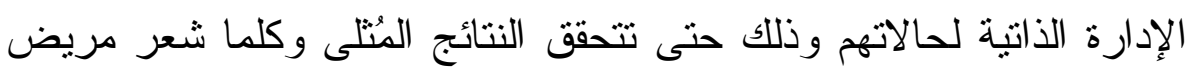

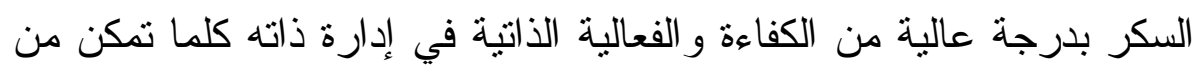
إدارة سلوكه الصحي مثل اتباع نظام غذائي أو ممارسة التدريبات الرياضية، وكلما تمكن من ضبط سكر الدم لديه (Wallston et al., 2007)؛ فالإدارة الذاتية الفعالة تمثل جزءً مهمًا من نموذج رئ رعاية الأمر اض المزمنة؛ حيث أنها تساعد في تحسين النتائج الصحية وخفض التكاليف، لقد تم تطوير العديد من التذخلات التعليمية و الإرشادية لدعم التغير السلوكي، وتحسين إدارة 
الذات لدى المرضى الذين يعانون من أمر اض مُزمنة، ولقد حققت البحوث

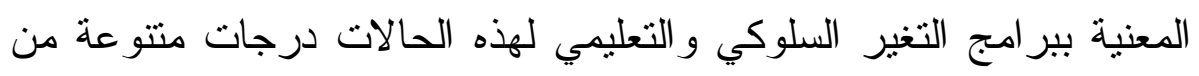
النجاح (Koetsenruijter et al., 2016).

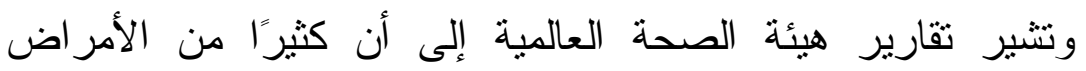

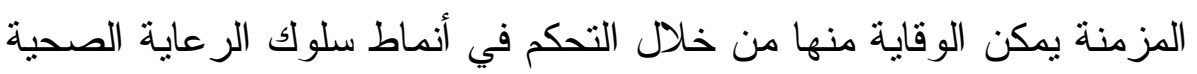

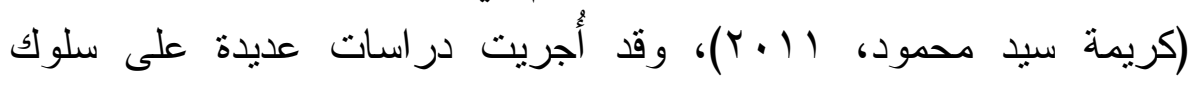

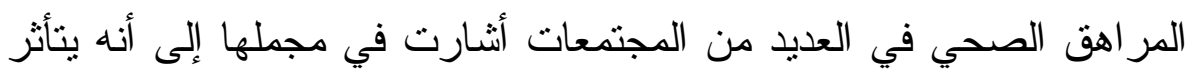
بالعديد من العوامل النفسية من بينها إدارة الذات (Shin \& Kang, 2014).

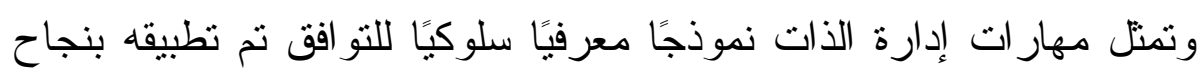

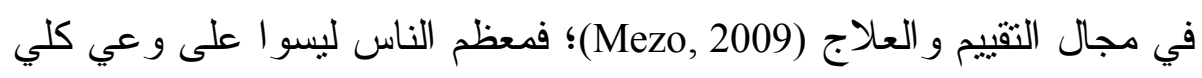

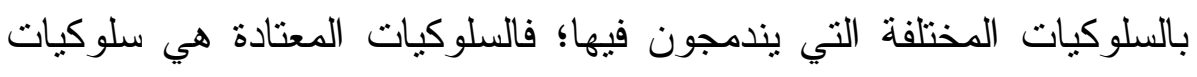

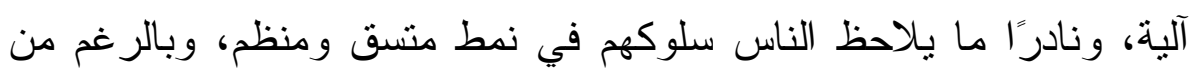

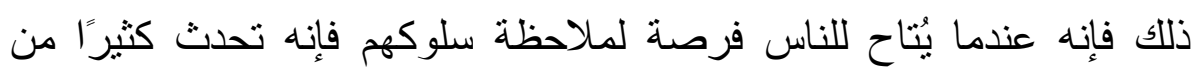

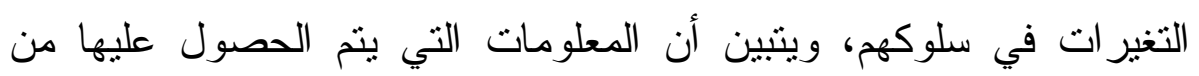

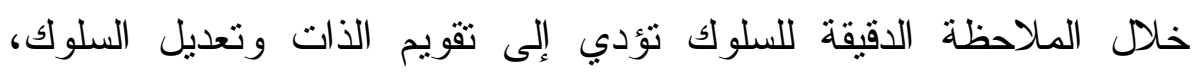

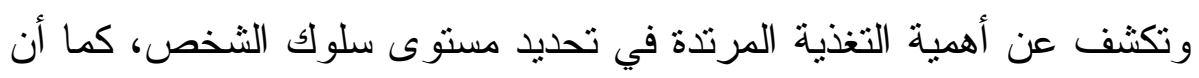

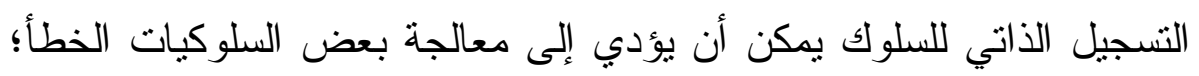

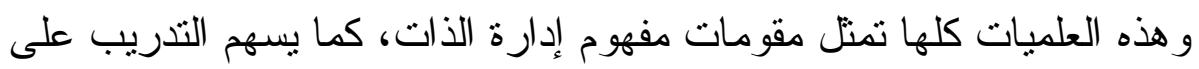

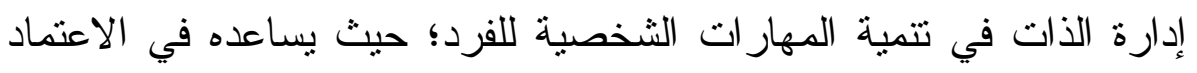

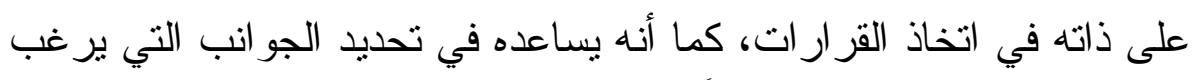

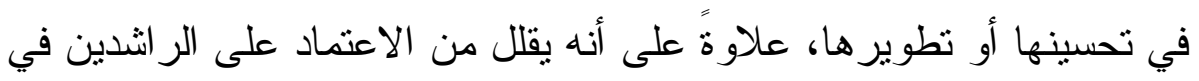

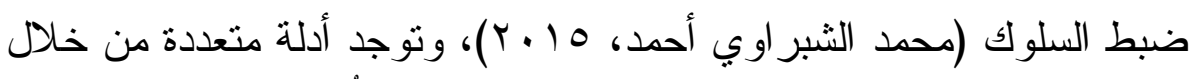

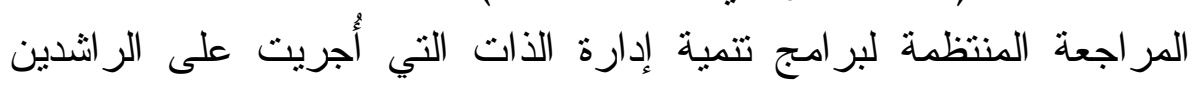

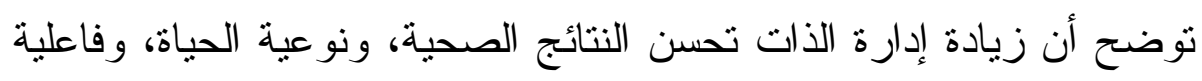

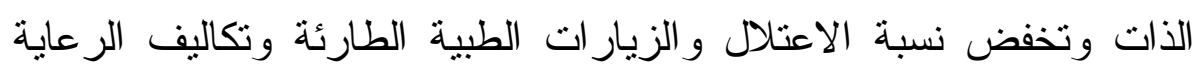


الصحية (Lindsay et al., 2014)

ثانيًا: يمكن تفسير هذه النتيجة أيضًا في ضوء بعض العو امل المتعلقة بالبرنامج الإنمائي، و أسسه وفنياته، حيث: هده: ا. تتوع روافد ومصارد بناء البرنامج؛ فقد تمت الإستفادة من البرامج

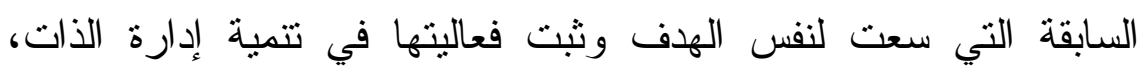
وتحسين السلوك الصحي؛ ففي ضوءها تم تحديد عدد جلسات البرنامج، وتحديد المدة الزمنية للجلسة الو احدة و انتقاء فنياته، و أنشطنه.

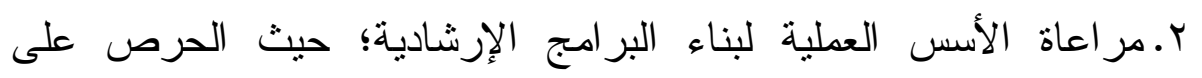
تشجيع المر اهقين على المشاركة بأنشطة البرنامج، وتقبلهم كما هم دون الإنياءيه

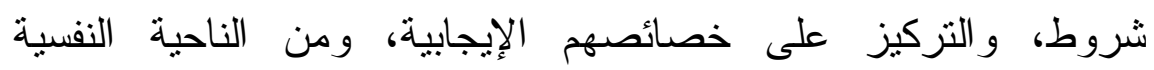
و التربوية فقد تم الاهتمام بالجوانب الدافعية عن طريق ربط أنشطة

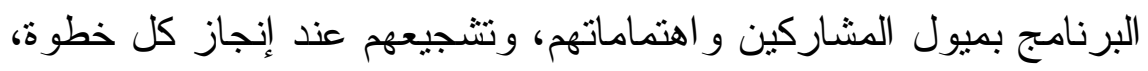

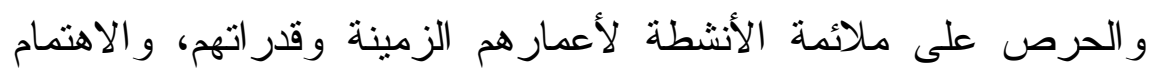

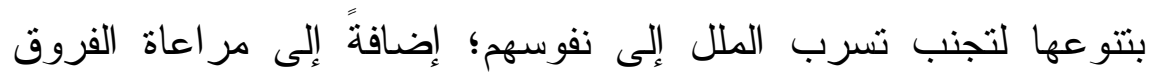

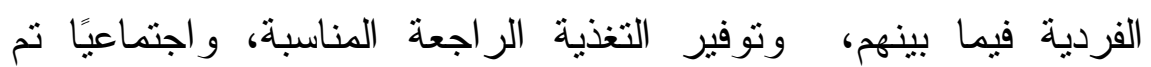

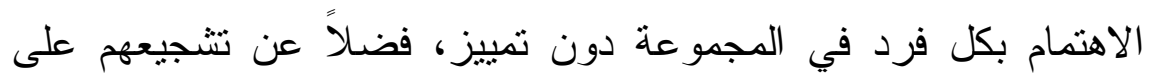
تكوين صداقات مع أقرانهم من خلال أداء الأنشطة الجماعية أثناء

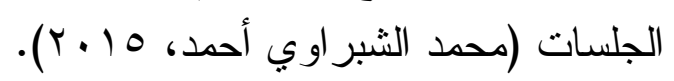

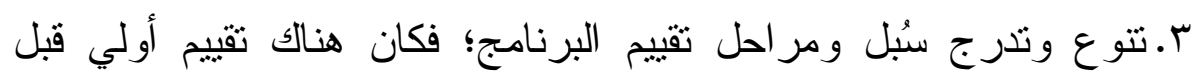

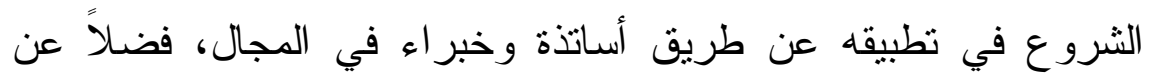

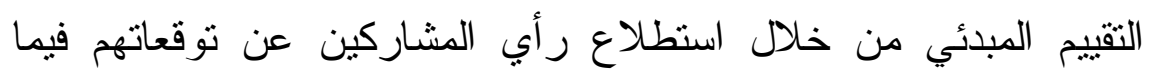
يتعلق بالبرنامج ومحتو اه، و التقييم المرحلي الذي كان يتم في نهاية كل جلسة، إضافة إلى تخصيص جلى ولسة في منتصف البرنامج للمر اجعة و التقييم، فضلاً عن التقييم النهائي؛ كل ذلك ساعد على تلافي الذي الأخطاء التي قد تعوق الاستفادة القصوى من البرنامج، فضلاً عن تقديم تغذية 
راجعة للباحثة ساعدت على تطوير الأداء بما بياعد على تحقيق الهدف النهائي.

ع. استخدام الإرشاد الجماعي؛ الذي يعمل على التقليل من تمركز العميل

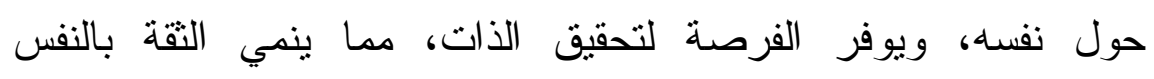

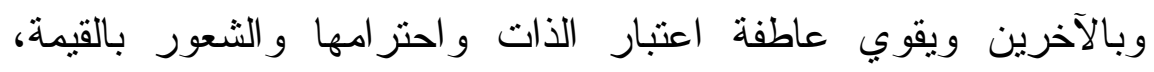

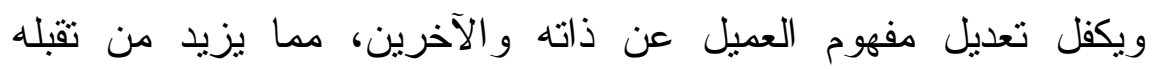

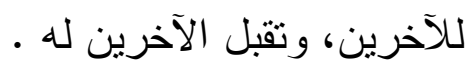

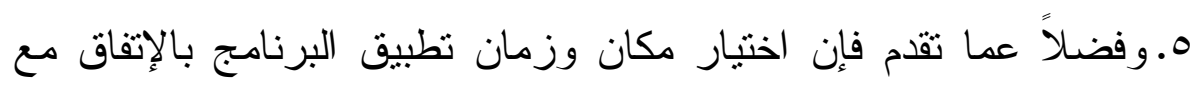

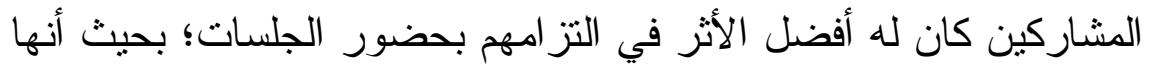

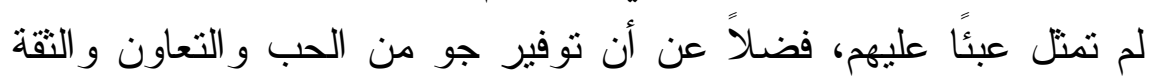

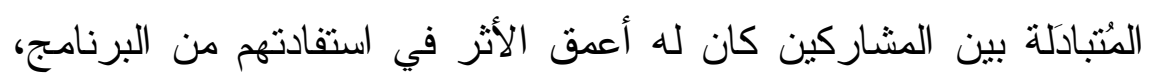

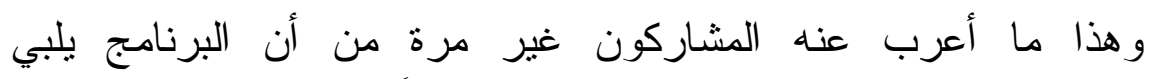

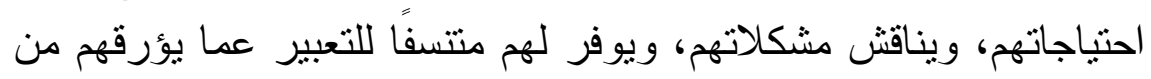

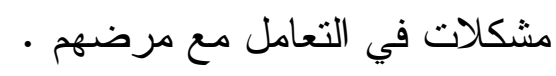
T.تتوع الأشطة و الفنيات التي وُظفت برته بالبرنامج لتقابل التتوع في السلوك

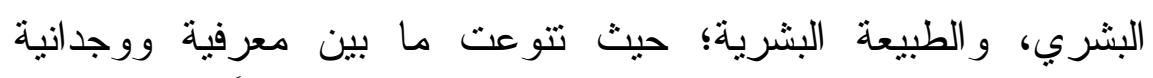
وسلوكية لتخاطب الثخصية الإنسانية بجو انبها الثلاثة؛ فمثناً:

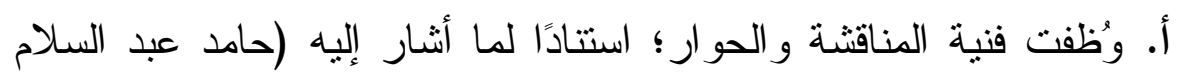

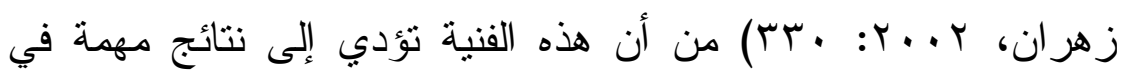

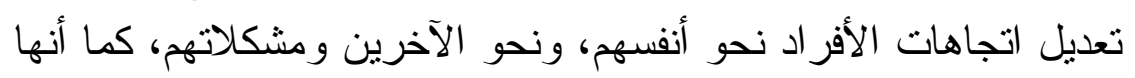

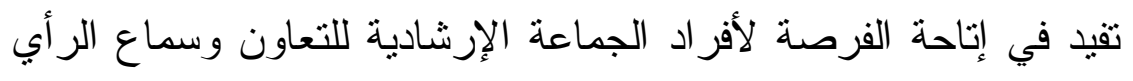

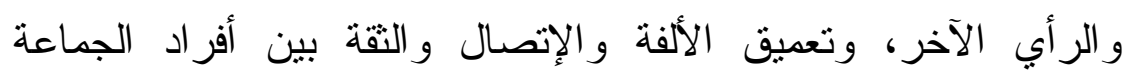

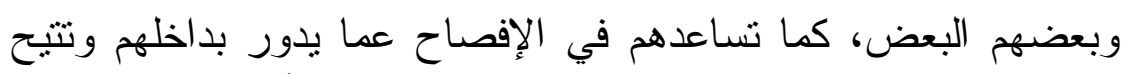

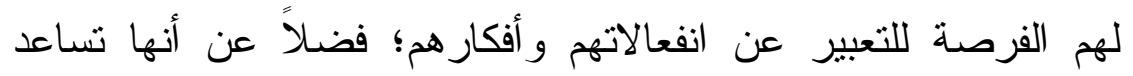

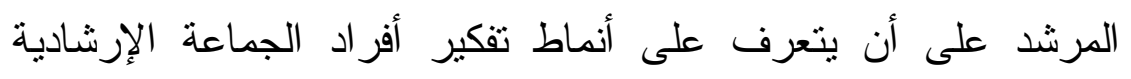




\section{و القضايا التي تشغلهم؛ فيحاول تفنيدها ومناقتشتها.} ب.أما فنية الإقناع اللفظي فإنها تلعب دورًا مهمًا في نجاح البرنامجٍ الإرشادي المُستخدم؛ لما لها من دور في إعادة البناء المعرفي، فضداًا عن نأثير ها في تحقيق ضبط النفس من جانب المسترشد، ويبدأ ذلك الدور بشرح منطق الإرشاد للمسترشد و إقناعه بضرورة هنئ الإلتز ام بـانه وتتفيذه و أداء ما يُطلب منه من مهام مختلفة، ومن واجبات منزلية

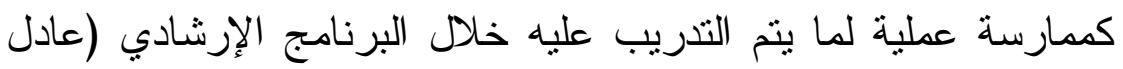

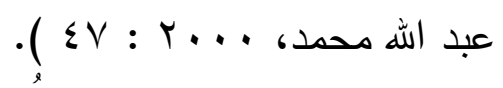
ج.كذلك فنية المحاضرة، و التي تُعتبر من أنجح السُبل الإرشادية لاعتمادها

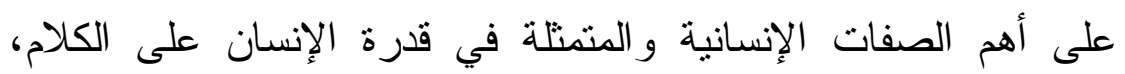
ونوظيف الرموز (محمد محروس الثناوي، 999 ( )). د. أما فنية التغذية الراجعة فنجد أن التعلم يتحسن حين يخبر المتعلم إذا كانت استجابته صحيحة أم لا ولماذا؟ و إذا لم تكن صحيحة يخبر باتجاه الخطأ، وتؤدي هذه المعلومات إلى تصميم المتعلم وتحكمه الذاتي في سلوكه، وبالتالي مزيد من التحسن في الأداء (آمال صادق، وفئ وفؤاد أبو

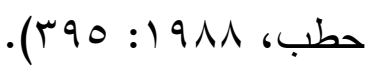

ه. إن الحرص على وجود واجب منزلي في نهاية كل جلسة كان بمثابة تفعيل لانتقال أثزر التدريب بما يساعد على التمكن من المهار ات المُتحعَمَة

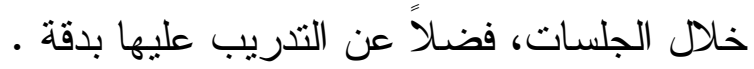
و. علاوةً على ما تقدم نجد فنية العصف الذهني، و التي تهدف لتحسين القدر ات العقلية و المعرفية، بالإضافة إلى المساعدة على التعاون و التفكير

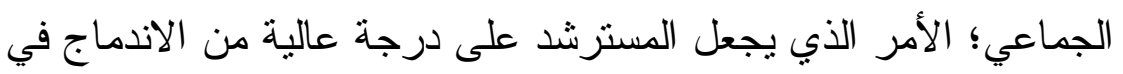
العمل و السعي إلى أداءه بكفاءة عالية . لمعل ثالثًا عينة الدراسة : فقد جاءت من المر اهقين مرضى السكر الذين

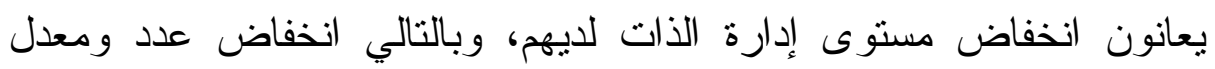


السلوكيات الصحية؛ ولقد ثبت علميًا أنه مع انتشار الأمراض المزمنة بين

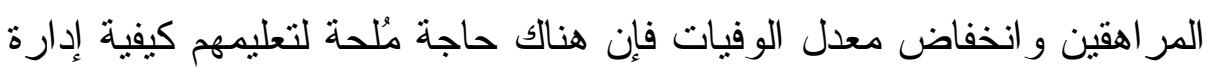

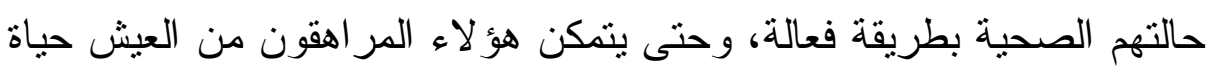

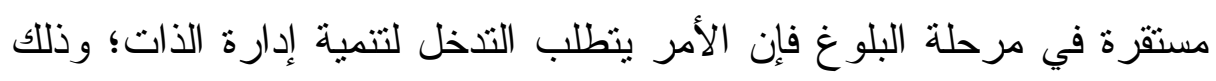

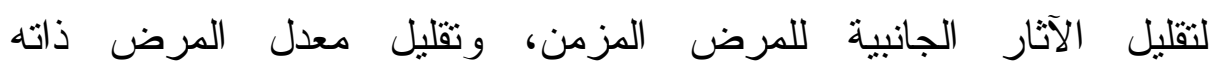

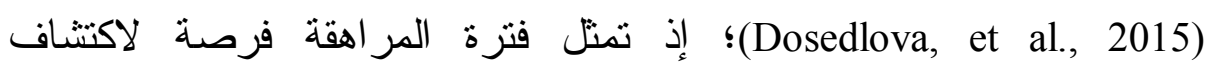

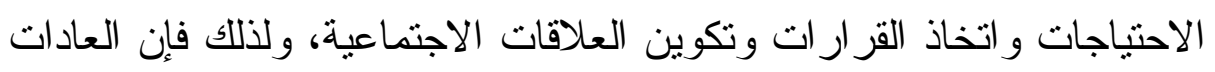

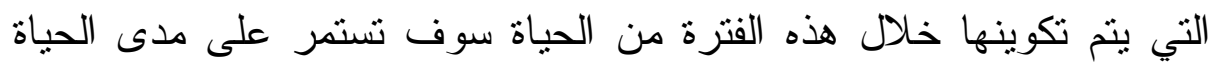

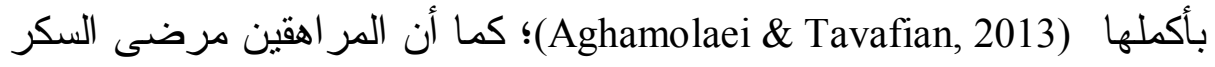

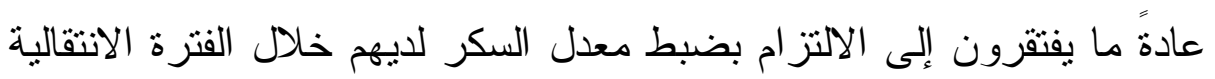

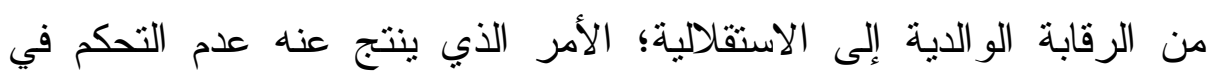
مستويات السكر وزيادة خطر المضاعفات الصحية (Bulaclac, 2011)؛

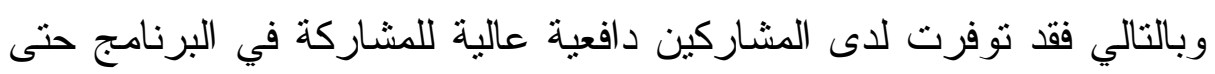

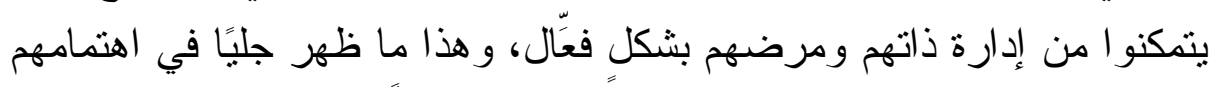

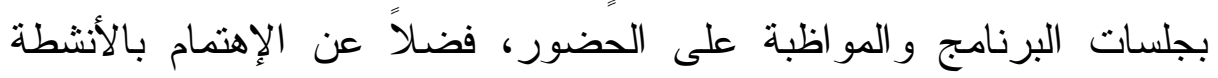

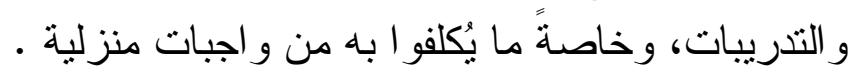

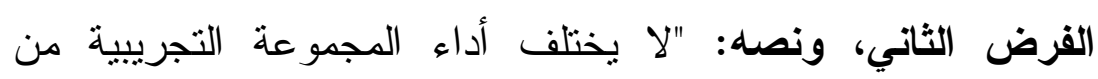

المر اهقين مرضى السكر على مقياس السلوك الصحي باختلاف القياسين

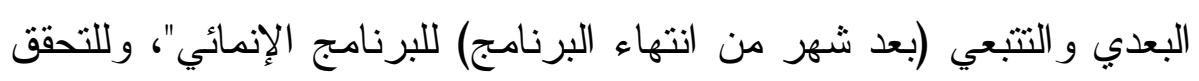

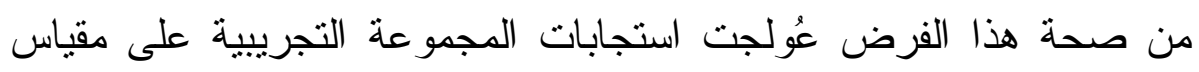

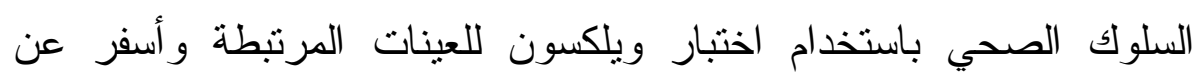
النتائج الثالية : 
فاعلية برنامج قائم على إدارة الذات في تحسين السلوك الصحي لاى المراهقين مرضى السكر

جدول (ץ) مجموع ومتوسطات الرتب وقيمة (Z) لالالة الفروق بين القياسين البعدي و التتبعي

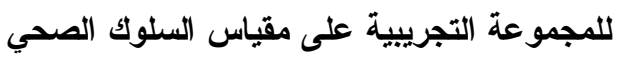

\begin{tabular}{|c|c|c|c|c|c|}
\hline الالالة & قيمة Z & متوسط الرتب & مجموع الرتب & عدد الرتب & المتغير \\
\hline \multirow{2}{*}{ غير دال } & \multirow{2}{*}{$v \cdot v-$} & $0, \varepsilon$ & $1 T, 0$ & r = الرتب السالبة r & \multirow{2}{*}{ الصحي } \\
\hline & & $0, \xi$ & rr,o & الرتب الموجبة = ه & \\
\hline
\end{tabular}

يضح من القيم المدونة بالجدول (r) تحقق صحة هذا الفرض حيث؛

بلغت قيمة " Z " لدلالة الفروق بين القياسين البعـدي و التتبعـي للمجموعـــة

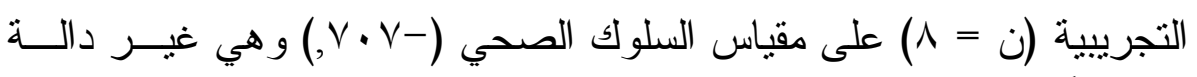

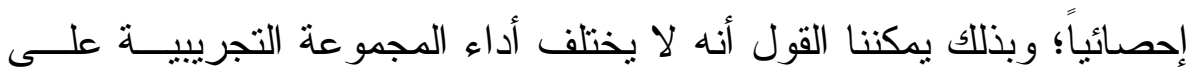

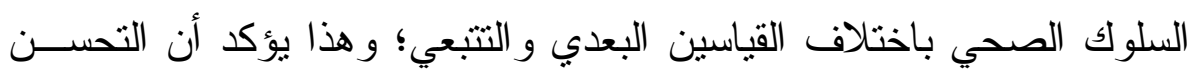

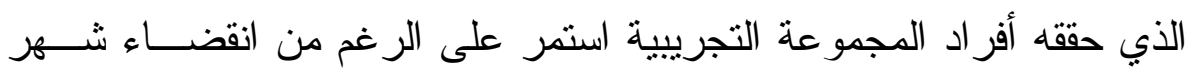

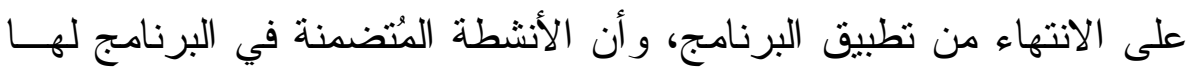

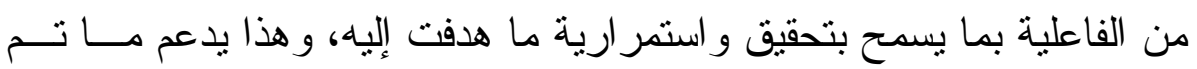

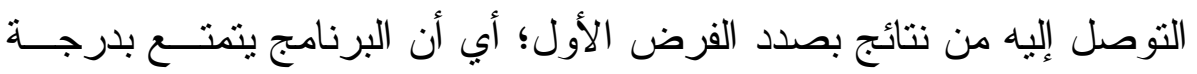

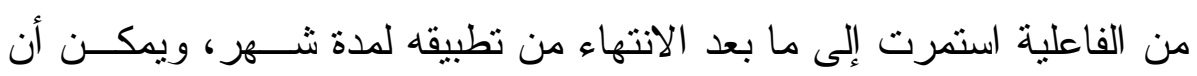

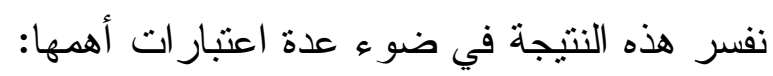
ا ـ بناء البرنامج؛ حيث التزم بالأسس العامة والأسس النفسية و التزبوية و الاجتماعيــة

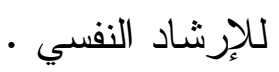

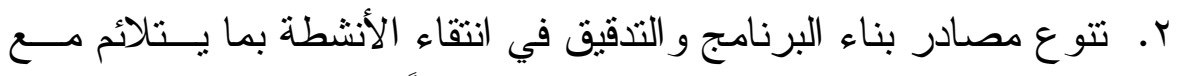

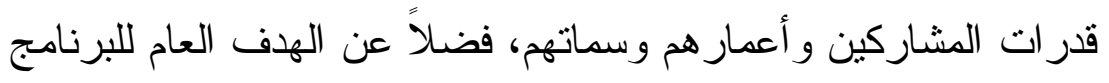
الإرشادي.

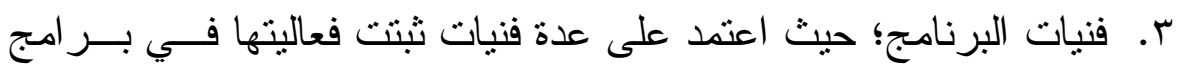
سابقة، كما تتوعت فنياته ما بين معرفية ووجدانية وسلوكية، وقد أورد بعض الباحثين أن الاستر اتيجيات السلوكية تؤدي إلى تنظيم المشـــاعر 
و الانفعالات المضطربة و التعبير عنها، وهو ما يؤدي بدوره إلى تحقيق

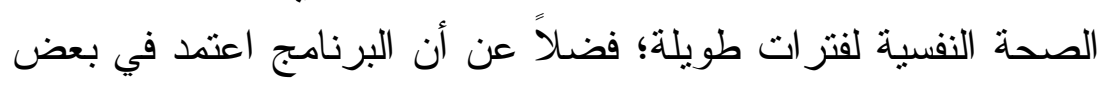

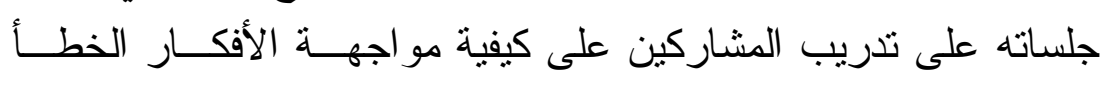

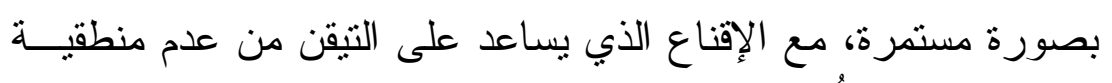

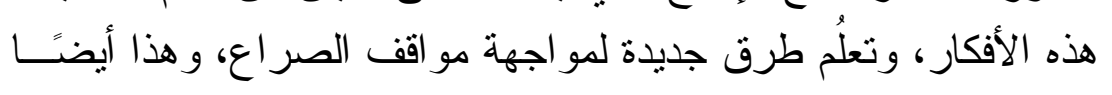

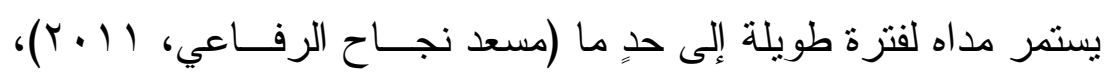

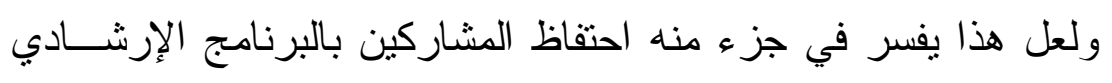

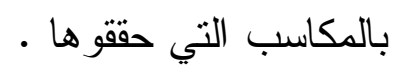

ع. كما أن توظيف البرنامج لفنية الواجب المنزلي ساعد على تعميق انتقال

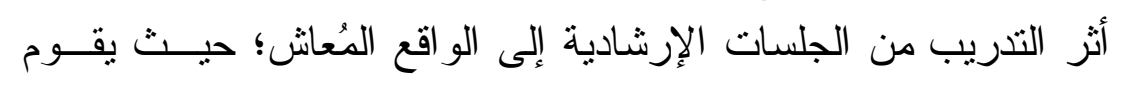

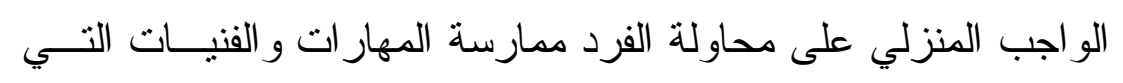

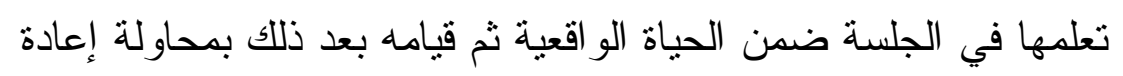

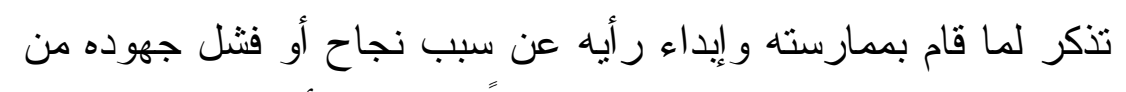

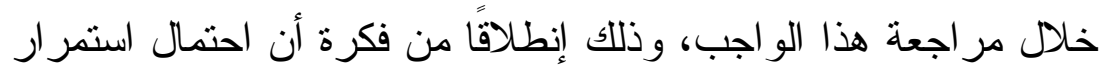

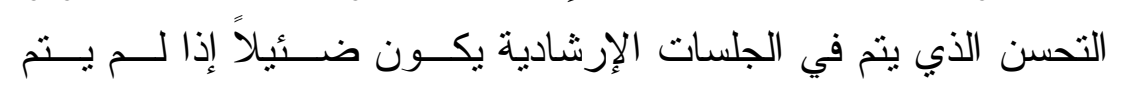

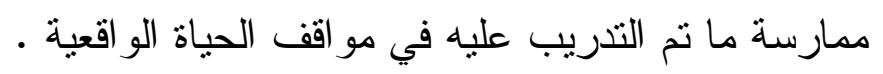

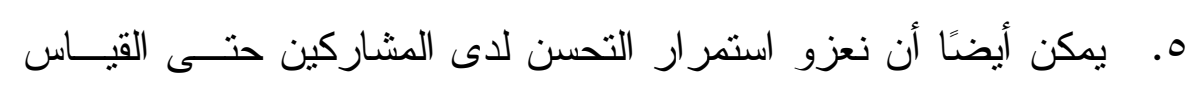

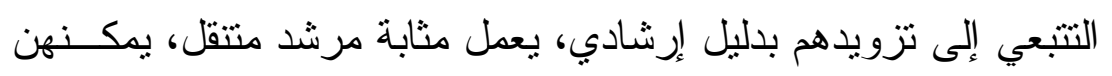

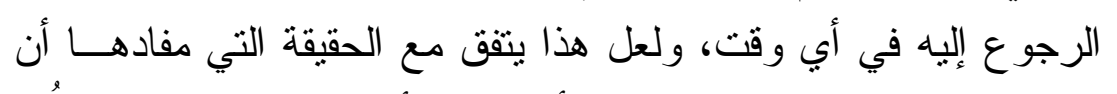

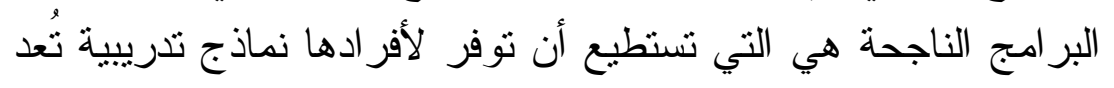

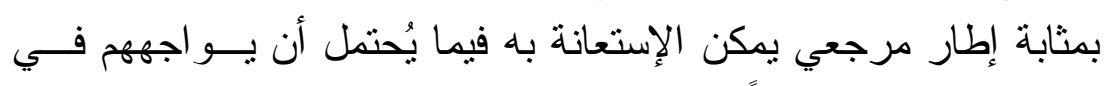

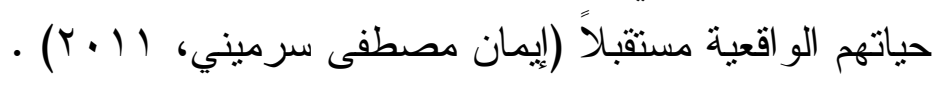

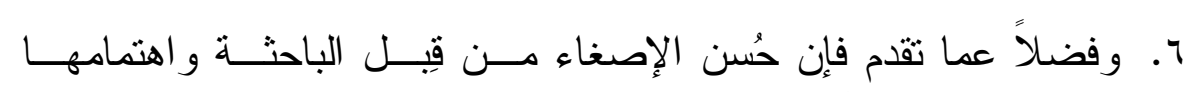

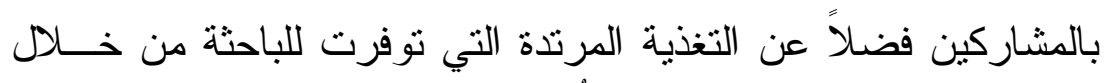

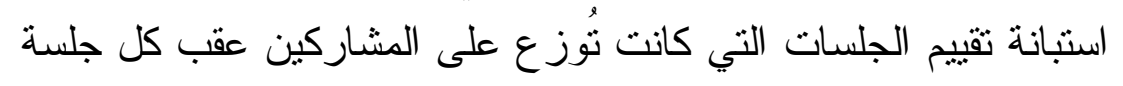




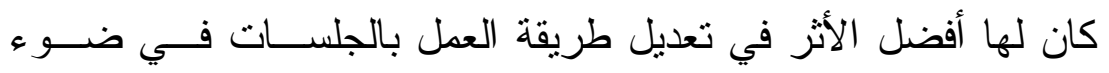

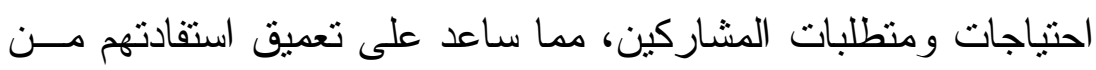
البرنامج، وهو ما أنعكس في بقاء أثزه حتى القياس التتبعي . الار اسات و التوصيات المُقترحة، وتتضمن ما يلي؛ أولاً الدراسات المُقترحة؛ في ضو ء مر اجعة الدر اسات السابقة، ونتائج هذه الدر اسة يمكن اقتر اح بعض الدر اسات المستقبلية على النحو التالي: ا ـ المتغير ات المُنبئة بالسلوك الصحي لدى المرضى بأمر اض مزمنة.

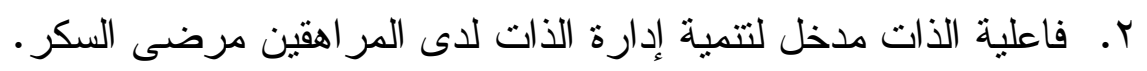
r. ت تتمية إدارة الذات لتحسين نوعية الحياة لدى مرضى السكر.

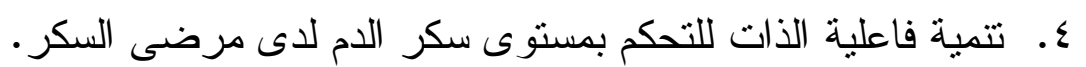

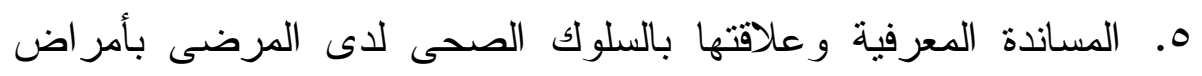
مزمنة.

ثناتيًا توصيات تطبيقية؛ في ضوء الميلاحظات الميدانية، وما توصلت إليه الدر اسة من نتائج، وكذلك نتائج الدر اسات السابقة فإنه يمكن الانتهاء إلى فئل التوصيات التالية: ا. عقد ندوات لتوعية الو الدين بضرورة دعم الجوانب الإيجابية لدى أبناءهم

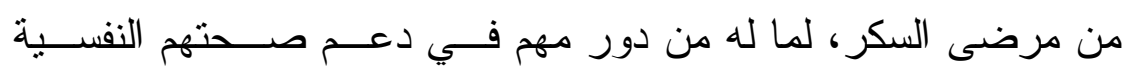
و البدنية.

r. . إعداد البر امج الوقائية و العلاجية التي تهدف دعم الصحة النفسـية لــدى المر اهقين مرضى السكر.

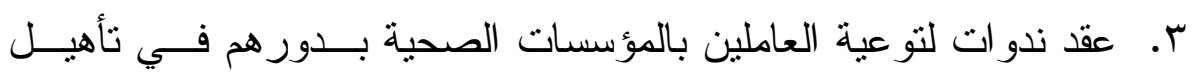

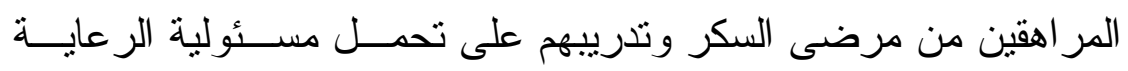

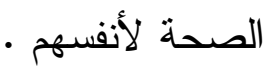


ع. تصميم بر امج إعلامية للمر اهقين مرضى السكر لتوعيتهم بمضــــاعفات وخطورة المرض، وتوعيتهم بأنماط السلوك الصحي المختلفة .

ه. تصميم بر امج إعلامية للمر اهقين مرضى الســكر لتــوعيتهم بالعلاقـة

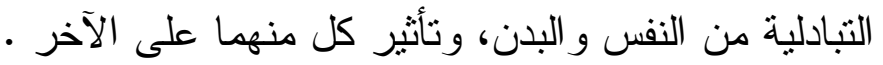




\section{المراجع}

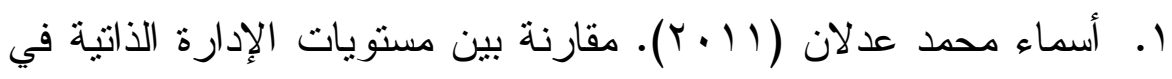

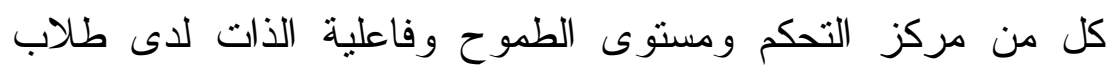
الجامعة. رسالة ماجستير (غير منشورة)، معهد الدراسات التزبوية، وفئ فئية جامعة القاهرة.

r. آمال صادق، وفؤاد أبو حطب (9^^ 1). علم النفس التربوي، طء. القاهرة: الأنجلو المصرية.

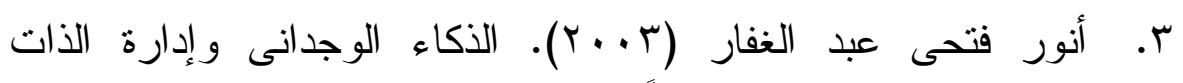
و علاقتهما بالتعلم الموجه ذاتياً لدى طلاب الدر اسات العليا كلية التربية.

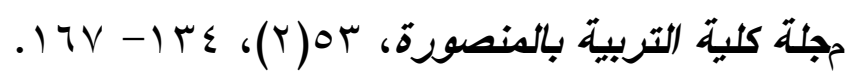

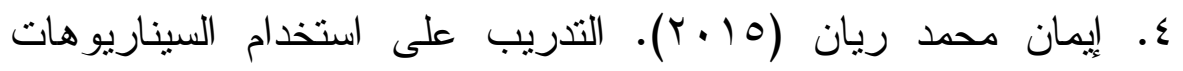

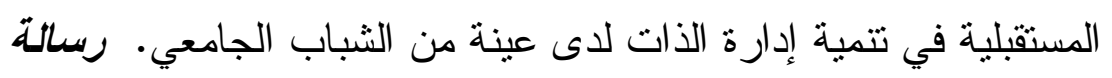
ماجستبر (غير منشورة). كلية التربية، جامعة عين شمس.

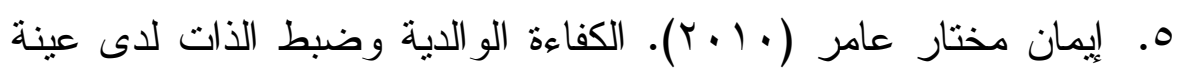
من تلاميذ المرحلة الإبتدائية. رسالة ماجستير (غير منشورة)، كلية

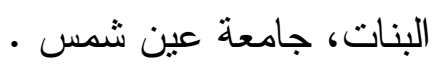

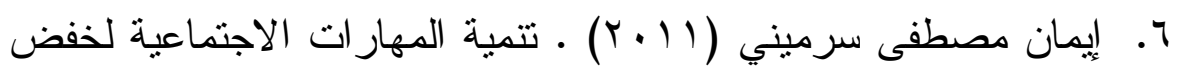

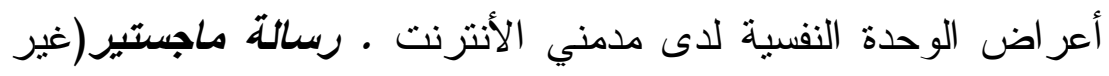

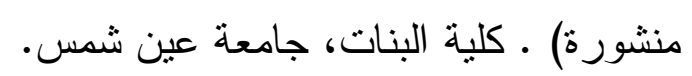

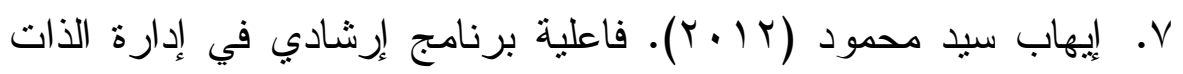

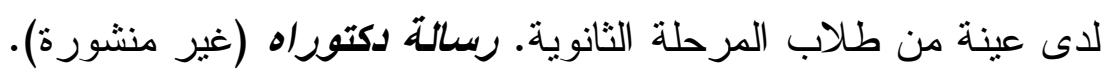
كلية التربية، جامعة عين شمس. ^. بسام خالد الطيارة (991 (1). السكري مرض العصنة العصر. بيروت: مؤسسة

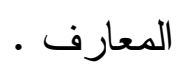




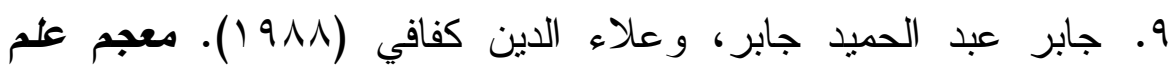

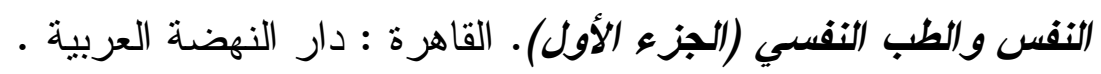

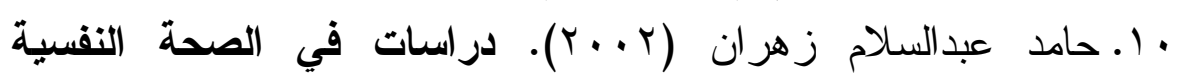

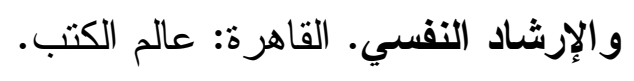

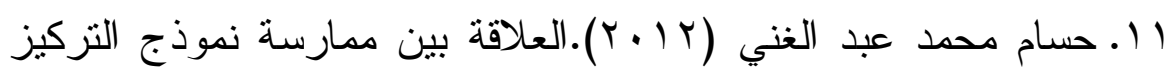

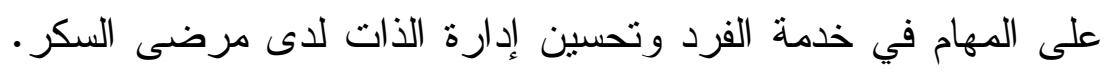

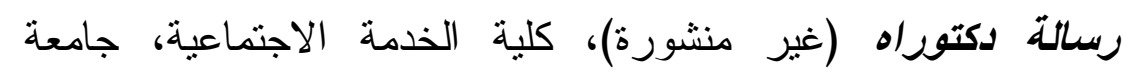
حلو ان.

r ا ـ خالد عبد اله المطيري (10 بـ). إدارة الفاعلية الأبوية ومهار ات إدارة

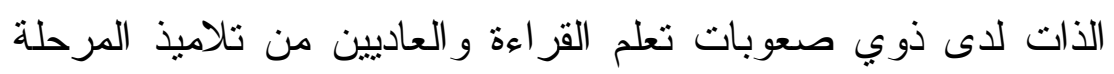

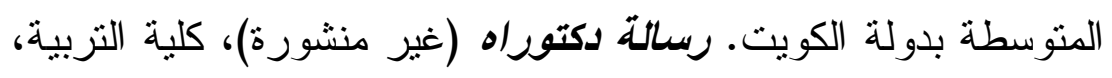
جامعة المنصورة.

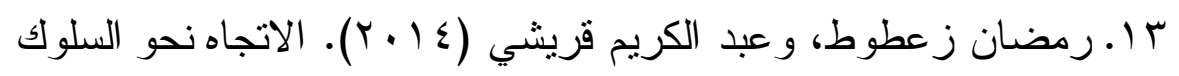

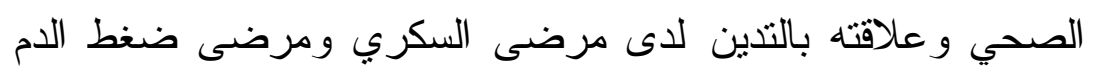

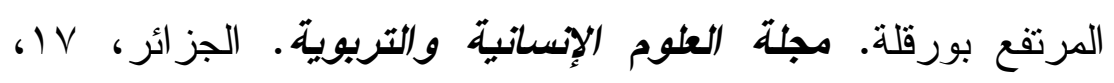
. rq $q$ - rvq

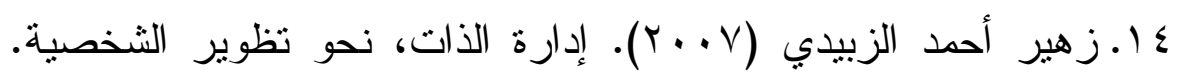
عمان : دار كنوز المعرفة العلمية.

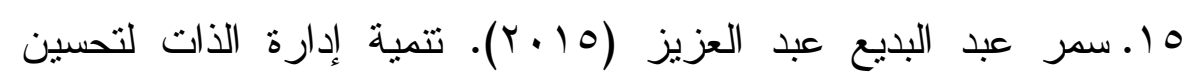

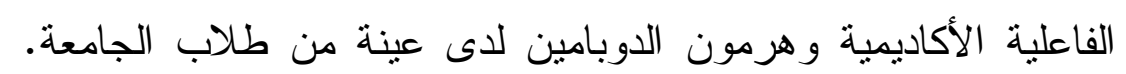

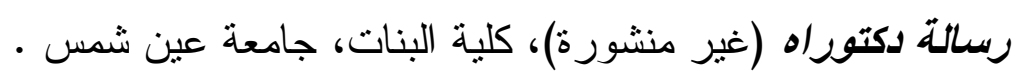

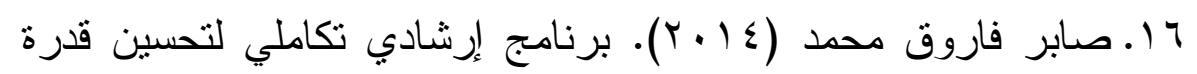

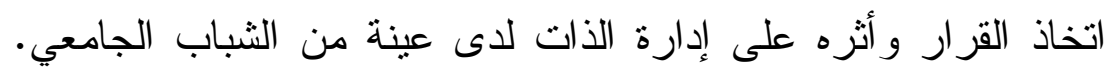

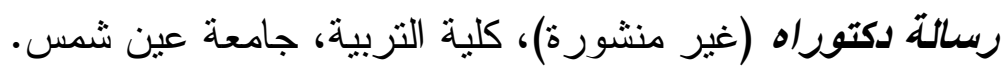


IV عادل عبد الله محمد (. . . . . . العلاج المعرفي السلوكي: أسس وتطبيقات. القاهرة: دار الرشاد.

1 1 . عبد الو هاب كامل (911 (1). مقياس التحكم الذاتحي (كراسة التعليمات). القاهرة: الأنجلو المصرية.

9 1. عزت عبد الحميد محمد (11 (Y). الإحصاء النفسي والتربيوي، تطبيقات باستخدام برنامج

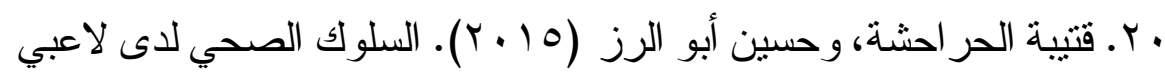
و لاعبات أنديه الإعاقة الحركية في الأردن . مجلة جامعة النجاح للأبحاث

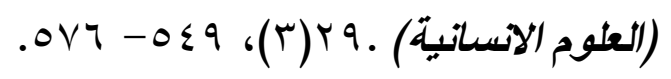

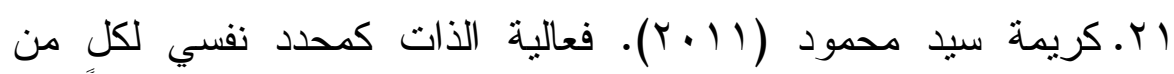
الإفصاح عن الذات و أنماط السلوك الصحي لدى عينة من الر اثدين.

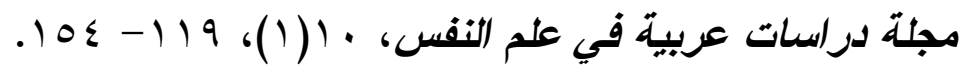

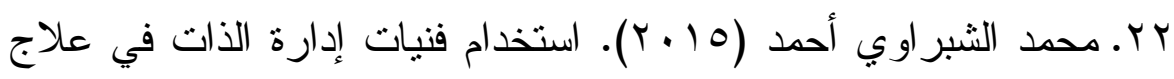
صعوبات نعلم القراعة لدى الأطفال. رسالة دكتوراه (غير منشورة). كلية التربية، جامعة عين شمس. r . محمد محروس الثناوي (799 1). العملية الإرشادية. القاهرة : دار غريب

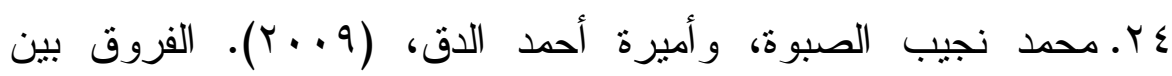
مرضى الكبد الفيروسي المزمن و الأصحاء. مجلة دراسات عربية في

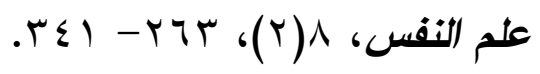

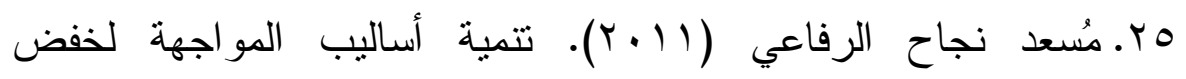
الأعر اض الإكلينيكية المصاحبة للأليكسيثيميا لدى عينة من الأطفال ذوي العر اض الذاتوية. رسالةة دكتوراه (غير منشورة) ـ كلية البنات، جامعة عين شمس. 


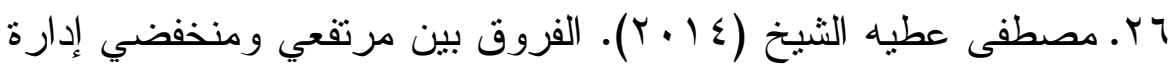
الذات في بعض المتغيرات المعرفية و الوجدانية لدى طلاب المرحلة

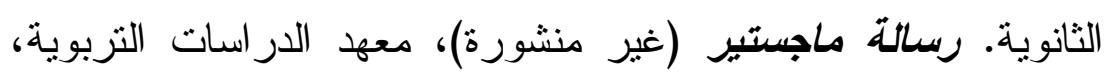
جامعة القاهرة.

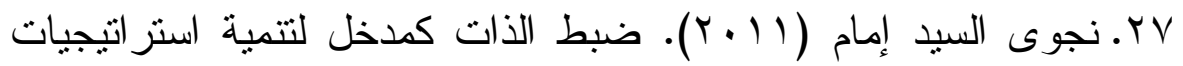
المو اجهة لدى معلمي التربية الخاصة. رسالة دكتوراه (غير منشورة)،

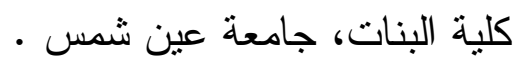

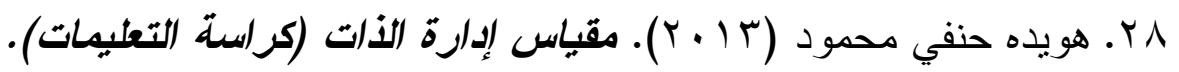

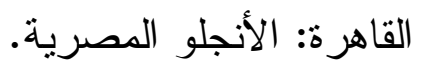

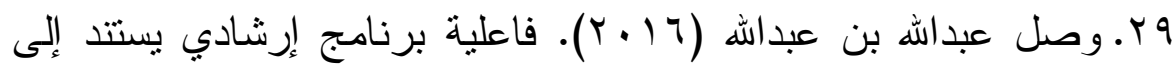

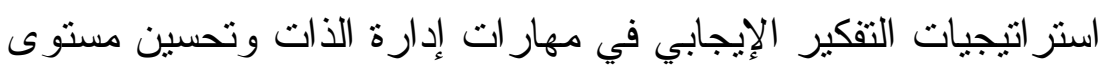

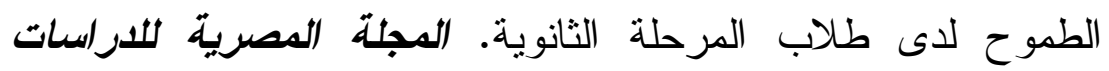

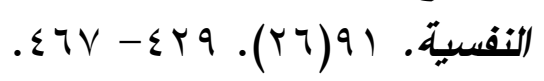

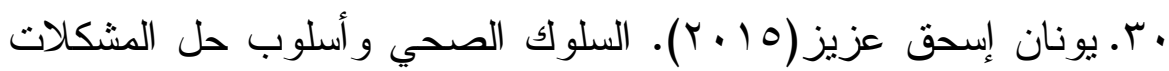

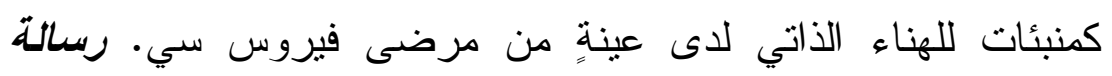
دكتوراه (غير منشورة)، كلية الآداب، جامعة المنيا.

31. Aghamolaei, T. \& Tavafian, S. S. (2013). Health behaviors of a sample of adolescents in Bandar Abbas, Iran. International Journal of High Risk Behavior \& addiction, 2(1), 34- 38.

32. Al-Khawaldah, O. A. Al-Hassan, M. A. \& Froelicher, E. S. (2012). Self-efficacy, self-management, and glycemic control in adults with type 2 diabetes mellitus. Journal of Diabetes and its Complications, 26(1), 10-16.

33. Alrahbi, H. (2014). Diabetes self-management (DSM) in Omani with type-2 diabetes. International Journal of Nursing Science, 1, 352- 359. 
فاعلية برنامج قائم على إدارة الذات في تحسين السلوك الصحي لاى المراهقين مرضى السكر

34. Auslander, W. F., Sterzing,P. R., Zayas, L. E. \& White, N. H. (2010). Psychosocial resources and barriers to self-management in African American adolescents with type 2 diabetes: $\boldsymbol{A}$ Qualitative Analysis, diabetes educator, 36(4), 613-622.

35. Barlow, J., Wright, C.; Sheasby, J.,; Turner, A. \& Hainsworth, J. (2002). Self-management approaches for people with chronic conditions: a review. Patient Education and Counseling, 48(2), 177-187.

36. Bulaclac, S. L. (2011). An internet-based self- management program to facilitate glycemic control in adolescents with type 1 diabetes mellitus. Unpublished Master's thesis, The Faculty of California State University.

37. Chen, M., Lai, L., Chen, H. \& Gaete, J. (2014). Development and validation of the short-form adolescent health promotion scale. BMC Public Health, 14,1106.

http://www.biomedcentral.com/1471-2458/14/1106.

38. Chen, M.Y., Wang, E. K., Yong, R.J. \& Liou, Y. M. (2003). Adolescent health promotion scale: development and psychometric testing. Publ Health Nurs, 20,104-110.

39. Cramm, J. M. \& Nieboer, A. P. (2012). Self-management abilities, physical health and depressive symptoms among patients with cardiovascular diseases. Chronic obstructive pulmonary disease and diabetes. Patient Education and Counseling. 87, 411-415.

40. Dosedlova, J., Klimusova, H., Buresova, I., Jelinek, M., Slevachova, A. \& Vasina, L. (2015).Optimism and healthrelated behavior in Czech university students and adults. Procedia - Social and Behavioral Sciences, 171,1051-1059. 
41. Ferguson, E. \& Danial, E. (1995). The illness attitude scale: A psychometric analysis in a non-clinical population. Personality \& Individual Differences, 18, 463- 469.

42. Grillo, M.; Neumann, C. R., Scain, S. F., Rozeni, R. F., Gross, J. L. \& Leitao, C.B. (2013). Effect of different types of selfmanagement education in patients with diabetes. Revista da Associacau Medica Brasileira. 59(4):400-405.

43. Guo, J.; Dixon, J. K.; Whittemore, R. \& He, G. P. (2012). Instrument translation and initial psychometric evaluation of the Chinese version of the self-management of type 1 diabetes for adolescents scale. Journal of Advanced Nursing 69(4), 960-969.

44. Guo, J., Whittemore, R.; Jeon, S.; Grey, M. \& Zhou, Z.(2015). Diabetes self-management, depressive symptoms, metabolic control and satisfaction with quality of life over time in Chinese youth with type 1 diabetes. Journal of Clinical Nursing, 24.910 .

45. Hooker, K., \& Kaus, C. R. (1994). Health-related possible selves in young and middle-adulthood. Psychology and Aging. 9, 126-133.

46. Hughes, A. E. (2011). Regulatory benefits of emotional processing \& self- control in adolescents with type 1 diabetes. Unpublished Master's Thesis, The University of Utah.

47. Huntsinger, E. T. \& Luecken, L. J. (2004). Attachment relationships and health behavior: The mediation role of selfesteem. Psychology and Health. 19 (4), 515-526.

48. Jaser, S. S., Faulkner, M. S., Whittemore, R.; Jeon, S., Murphy, K. \& Delamater, A. \& Grey, M. (2012). Coping, selfmanagement, and adaptation in adolescents with type 1 
فاعلية برنامج قائم على إدارة الذات في تحسين السلوك الصحي لاى المراهقين مرضى السكر

diabetes. The Society of Behavioral Medicine, 43(3), 311319.

49. Klassen, A. F., Grant, C., Barr, R.; Brill, H.; Kraus de Camargo, O.; Ronen, G. M.; Samaan, M. C.; Mondal, T., Cano, S. J., Schlatman, A., Tsangaris, E., Athale, U.; Wickert, N. \& Gorter, J.W. (2015). Development and validation of a generic scale for use in transition programmes to measure selfmanagement skills in adolescents with chronic health conditions: The Transation-Q. Child: Care, Health and Development, 41(4), 547-558.

50. Koetsenruijter et al., (2016). Social support and selfmanagement capabilities in diabetes patients: An international observational study. Patient Education and Counseling, 99, 638-643.

51. Law, G. U., Kelly, T. P., Huey, D. \& Summerbell, C. (2002). Self - management and well-being in adolescents with diabetes mellitus: do illness representations play a regulatory role? The Journal of Adolescent Health: Official Publication of the Society for Adolescent Medicine, 31.(4), 381-385.

52. Lee, C. L.; Lin, C. C. \& Anderson, R. (2016). Psychometric evaluation of the Diabetes Self-Management Instrument Short Form (DSMI-20). Applied Nursing Research, 29, 83-88.

53. Lindsay, S.; Kingsnorth, Sh., Mcdougall, C. \& Keating, H. (2014). A systematic review of self-management interventions for children and youth with physical disabilities. Disability $\&$ Rehabilitation, 36(4): 276-288.

54. Luyckx, K. (2012). Coping, Self-management, and Adaptation in Adolescents with Type 1 Diabetes. The Society of Behavioral Medicine, 43, 282-283. 
55. Mc Gowan, P. (2015). The Relative effectiveness of selfmanagement programs for type 2 diabetes. Canadian Journal of Diabetes. 39, 411-419.

56. Mezo, P. G. \& Short, M. M. (2012). Construct Validity and Confirmatory Factor Analysis of the Self-Control and SelfManagement Scale. Canadian Journal of Behavioral Science. 44 (1), 1-8.

57. Mezo, P. G. (2009). The Self-control and self-management scale (SCMS): Development of an adaptive self-regulatory coping skills instrument. Journal of Psychopathology Behavior Assessment, 31:83-93 DOI 10.1007/s10862-0089104-2.

58. Moreno, J. P., Kelley, M. L, Landry, D., Paasch, V., Terlecki, M. A., Johnston C. A. \& Foreyt, J. P. (2011). Development and validation of the Family Health Behavior Scale, International Journal of Pediatric Obesity, 6, 480-486.

59. Mulvancy, S. A.; Rothman, R. L.; Wallston, K. A.; Lybarger, C. \& Dietrich, M. S. (2010). An internet based program to improve self-management in adolescents with type 1 diabetes. Diabetes Care, 33(3), 602- 604.

60. Musekampa, G., Bengelb, J., Schulera, M. \& Faller, M.(2015). Improved self-management skills predict improvements in quality of life and depression in patients with chronic disorders. Patient Education and Counseling. http://dx.doi.org/10.1016/j.pec.2016.03.022.

61. Nguyen, A. L., Green, J. \& Enguidanos, S. (2015). The relationship between depressive symptoms, diabetes symptoms, and self-management among an urban, low-income Latino population. Journal of Diabetes and Its Complications, 29,1003-1008. 
فاعلية برنامج قائم على إدارة الذات في تحسين السلوك الصحي لاى المراهقين مرضى السكر

62. Opipari- Arrigan, L., Kichler, J. \& Fredericks, E., Burkhart, N. (2005). Self-management intervention improve diabetes related functioning in at risk adolescents with type 1 diabetes. ProQuest Central. 54, A455.

63. Rorres. R. (1995). Self-esteem and value of health as correlates of adolescent health behavior. Adolescence, 30 (118), 403-412.

64. Rothman, R. L., Mulvaney, S.; Elasy, T. A., VanderWoude, A.; Gebretsadik, T. et al. (2008). Self-Management Behaviors, Racial Disparities, and Glycemic Control Among Adolescents With Type 2 Diabetes. Pediatrics. 121,4, E912.

65. Sadeghiam, H. A. ; Madhu, S. V.; Agrawal, K.; Kannani, A. T.; Agrawal, K. (2016). Effects of a self-management educational program on metabolic control in type 2 diabetes. Turkish Journal of Medical Sciences, 46, 719-726,

66. Sarkar, U.; Fisher, L. \& Schillinger, D. (2006). Is self-efficacy associated with diabetes self-management across race/ethnicity and health literacy? Diabetes Care, 29 (4), 823- 829.

67. Sawyer, S. M. \& Aroni, R.A. (2005). Self-management in adolescents with chronic illness. What does it mean and how can it be achieved? Medical Journal of Australia, 183 (8), 405- 408.

68. Schmitt A., Reimer, A., Hermanns, N., Huber J., Ehrmann D., Schall, S., et al. (2016). Assessing diabetes self-management with the diabetes self- management questionnaire (DSMQ) can help analyses behavioral problems related to reduced glycemic control. Public Library of Science. (PLoS ONE) 11(3), e0150774.

69. Schuurmans. H., Steverink, N., Frieswijk N., et al. (2005). How to measure self-management abilities in older people by self- 
report? The development of the SMAS-30. Qual Life Res. 14, 2215-2228.

70. Shakibazadeh, E., Rashidian, A., Larijani, B. \& Shojaeezadeh, D. (2012). Psychometric properties of the iranian version of resources and support for chronic illness self-management scale in patients with type 2 diabetes. International Journal of Preventive Medicine, 3:84-90.

71. Shin, Y. H. \& Kang, S. J. (2014). Health behaviors and related demographic factors among Korean adolescents. Asian Nursing Research, 8, 150-157.

72. Shin, Y. H. (2010). Development and psychometric evaluation of a scale to measure health behaviors of adolescents. Journal of Korean Academy of Nursing, 40(6), 820-830.

73. Song, A.; Xu, T. \& Sun, Q. (2014). Effect of motivational interviewing on self-management in patients with type 2 diabetes mellitus: A meta-analysis. International Journal of Nursing Science. 1, $291-297$.

74. Storch, E. A., Heidgerken, A. D., Geffken, G. R.; Lewin, A. B.; Ohleyer, V.; Freddo, M.\& Silverstein, J. H. (2006). Bullying, regimen self-management, and metabolic control in youth with type I diabetes. The Journal of Pediatrics, 148, (6), 784-787.

75. Tangney, J.P., Baumeister, R.F. \& Boone, A.L. (2004). High self-control predicts good adjustment, less pathology, better grades, and interpersonal success. Journal of Personality, 271324.

76. Taylor, S. E. (2003). Health psychology, (5 ed.) New York: Mc Graw-Hill. 
فاعلية برنامج قائم على إدارة الذات في تحسين السلوك الصحي لاى المراهقين مرضى السكر

77. Thompson, A. (2010). The relationship among health literacy, self -efficacy, \& self -management of individuals with diabetes. (phd.), Texas Women's University.

78. Vanden Bos, G. R. (Ed.) (2007). American Psychological Association (APA) Dictionary of psychology. American Psychological Association, Washington, DC.

79. Verchota, G. M. (2014). Testing components of a selfmanagement theory in adolescents with typel diabetes mellitus. (phd.), , The University of Wisconsin-Milwaukee.

80. Vickers, R. R., Conway, T. L., \& Hervig, L. K. (1990). Demonstration of replicable dimensions of health behaviors. Preventive Medicine, 19, 377-401.

81. Wallston, K. A.; Rothman, R. L. \& Cherrington, A. (2007). Psychometric Properties of the Perceived Diabetes SelfManagement Scale (PDSMS). Journal of Behavioral Medicine,30, 395-401.

82. Xue, G. \& Sun, X. (2012). Construction and validation of selfmanagement scale for undergraduate students. Creative Education, 2(2), 142-147. 0

83. Yin, X., Wei, P. \& Hong, L. (2010). Self-management practices of Chinese Americans with type 2 diabetes. Nursing and Health Sciences, 12.(2), 228-234.

84. Zhang, C., Wang, W., Li, J., Cai, X.; Zhang, H., Wang, H. \& Wang, X. (2013). Development and validation of a COPD selfmanagement scale. Respiratory Care, 58(11):1931-1936. 